\title{
TRANSFORMAÇÃO GENÉTICA DE Eucalyptus grandis E DO HÍBRIDO E. grandis $x$ E. urophylla VIA Agrobacterium
}

\section{ESTEBAN ROBERTO GONZÁLEZ}

\author{
Tese apresentada à Escola Superior de Agricultura \\ "Luis de Queiroz", Universidade de São Paulo, para \\ obtenção do título de Doutor em Agronomia, Área de \\ Concentração: Genética e Melhoramento de Plantas.
}

\author{
PIRACICABA \\ Estado de São Paulo - Brasil \\ Abril - 2002
}




\title{
TRANSFORMAÇÃO GENÉTICA DE Eucalyptus grandis E DO HÍBRIDO E. grandis $x$ E. urophylla VIA Agrobacterium
}

\author{
ESTEBAN ROBERTO GONZÁLEZ \\ Licenciatura en Genética
}

Orientador: Prof. Dr CARLOS ALBERTO LABATE

\begin{abstract}
Tese apresentada à Escola Superior de Agricultura
"Luis de Queiroz", Universidade de São Paulo, para obtenção do título de Doutor em Agronomia, Área de Concentração: Genética e Melhoramento de Plantas.
\end{abstract}

PIRACICABA

Estado de São Paulo - Brasil

Abril - 2002 


\section{Dados Internacionais de Catalogação na Publicação (CIP)}

DIVISÃO DE BIBLIOTECA E DOCUMENTAÇÃO - ESALQ/USP

\section{González, Esteban Roberto}

Transformação genétic a de Euc a lyptus grandis e do híbrido $\mathrm{E}$. gra ndis $\mathrm{x}$ E. urophylla via Agrobacterium / Esteban Roberto González. - - Piracicaba, 2002.

93 p. : il.

Tese (doutorado) - Escola Superior de Agricultura Luiz de Queiroz, 2002. Bibliografia.

1. Euc alipto 2. Melhoramento genétic o vegetal 3. Morfologia vegetal 4. Planta transgênica 5. Sementes-transformação I. Título

CDD 634.9734 
Aos meus pais ROBERTO e NILDA e à minha avó JOSEFINA, pela orientação essencial que deram à minha vida e pelos seus ideais, que fizeram de mim o que sou. Apesar da distância eles vivem todos os meus fracassos e minhas vitórias.

\section{OFEREÇO}

A minha namorada, LUCIANA pelo amor e apoio, que faz com que todos os caminhos de minha vida sejam mais fáceis e os problemas menores. Pelo presente e pelo futuro...

\section{DEDICO}




\section{AGRADECIMENTOS}

Ao Prof. Dr. Carlos Alberto Labate, pela oportunidade, orientação, amizade e sinceridade que caracterizou nosso trabalho.

À Dra. Mônica T. Labate pela amizade e auxílio constante no trabalho.

Ao grupo de pesquisa em Eucalyptus, que tornaram possível a realização desta tese, contribuindo com trabalhos em conjunto e troca de informações: Alexander, Valeria, Gisele, Raphael, Paulo, Carol, Aline, Erica, Palmira e Fernanda e aos que passaram pelo grupo: Leticia, Alejandro, Silvia e Gustavo.

À Companhia Suzano de Papel e Celulose pelo apoio, especialmente a Shinetiro e Eduardo, que além de acompanharem o trabalho, colaboraram constantemente nas discussões dos experimentos.

Aos meus irmãos Pablo e Gabriel, pelo apoio.

Aos professores do Departamento de Genética pelos ensinamentos.

Aos amigos do laboratório, Guillermo, Altamir, Marcelo, Raqueline, Daniela, Danielle, Paulo Barja, Gunta, Juliano, Karen, João e Felipe, pela amizade e agradável convivência.

Aos amigos e colegas de república, Alexander, Alejandro e Guillermo.

Aos amigos e colegas de futebol, José, Boi, Renato, Guilherme.

A Lilian e Roberto, pela amizade

A todos os amigos pelos grandes momentos que compartilhamos.

A todos os colegas e funcionários da Genética e da ESALQ.

À CAPES e CNPq pelas concessões das bolsas.

A todos que, de alguma forma, contribuíram para a realização desta tese. 


\section{SUMÁRIO}

Página

ABREVIATURAS E SÍMBOLOS..................................................... ix

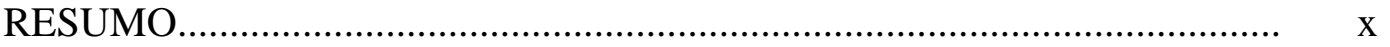

SUMMARY ............................................................................. xii

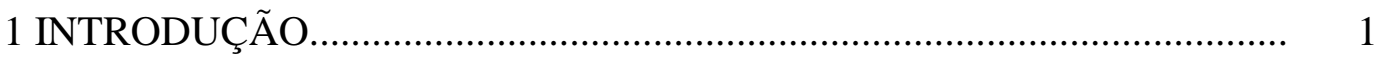

2 REVISÃO DE LITERATURA......................................................... 5

$2.1 \mathrm{O}$ gênero Eucalyptus.................................................................... 5

2.2 Transformação genética de plantas...................................................... 8

2.2.1 Regeneração in vitro ........................................................................... 8

2.2.2 Transferência do DNA........................................................................ 13

2.2.3 Seleção de tecidos transgênicos...................................................... 17

2.3 Caracterização de plantas transgênicas................................................... 18

2.3.1 Coloração histoquímica da $\beta$-glucuronidase (GUS)............................ 18

2.3.2 Detecção de transgenes por PCR ...................................................... 20 
3 SISTEMA DE REGENERAÇÃO DE PLANTAS A PARTIR DE TECIDOS DE PLÂNTULAS E CLONES DE Eucalyptus grandis E DE E. grandis $x$ E. urophylla.

Resumo 23

Summary

3.1 Introdução 26

3.2 Material e Métodos 27

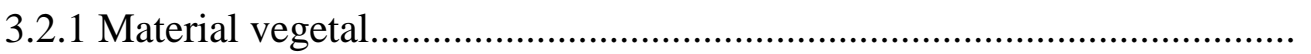

3.2.2 Indução de calos.

3.2.3 Indução de gemas

28

3.2.4 Multiplicação e alongamento de brotos

3.2.5 Avaliação da eficiência de regeneração de diferentes explantes de $E$. grandis, E. urophylla e do híbrido entre ambos. 30

3.2.6 Efeito dos reguladores de crescimento na eficiência de regeneração. 31

3.2.7 Regeneração de clones comerciais de E. grandis.

3.2.8 Enraizamento e aclimatação

3.3 Resultados e Discussão

3.3.1 Avaliação da eficiência de regeneração de diferentes explantes de $E$. grandis, E. urophylla e do híbrido (E. grandis $x$ E. urophylla)............... 33

3.3.2 Efeito dos reguladores de crescimento na eficiência de regeneração de cotilédones. 
3.3.4 Enraizamento e aclimatação.......................................................... 40

3.4 Conclusões................................................................................. 41

4 OBTENÇÃO DE PLANTAS TRANSGÊNICAS DE Eucalyptus grandis E E. grandis $x$ E. urophylla MEDIANTE INOCULAÇÃO COM Agrobacterium ................................................................................... 43

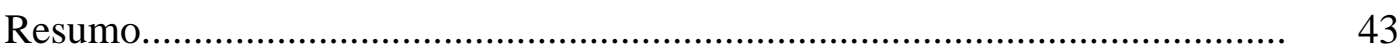

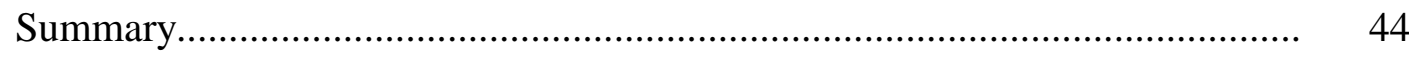

4.1 Introdução.................................................................................... 45

4.2 Material e Métodos....................................................................... 47

4.2.1 Material vegetal...................................................................... 47

4.2.2 Linhagens, plasmídeos e condições de cultura da A. tumefaciens............ 47

4.2.3 Inoculação e co-cultura................................................................ 48

4.2.4 Ensaio histoquímico da $ß$-glucuronidase ........................................ 49

4.2.5 Análise dos dados................................................................ 50

4.2.6 Efeito dos estádios de desenvolvimento das sementes e da sonicação na eficiência de transformação............................................................... 50

4.2.7 Efeito do tempo de sonicação na eficiência de transformação................. 51

4.2.8 Influência dos diferentes meios e condições de luminosidade durante o co-cultivo na eficiência de transformação............................................ 52

4.2.9 Tolerância de E. grandis a diferentes agentes seletivos........................ 54 
4.2.10 Avaliação da susceptibilidade de E. grandis, E. urophylla e do híbrido entre ambos à linhagem LBA4404 de A. tumefaciens. 55

4.2.11 Seleção, regeneração e obtenção de plantas transgênicas...................... 55

4.2.12 Extração de DNA e hibridização por Southern blot.............................. 56

4.3 Resultados e Discussão................................................................ 57

4.3.1 Efeito dos estádios de desenvolvimento das sementes e da sonicação na eficiência de transformação................................................................... 57

4.3.2 Efeito do tempo de sonicação na eficiência de transformação................. 60

4.3.3 Influência dos diferentes meios e condições de luminosidade durante o co-cultivo na eficiência de transformação............................................ 62

4.3.4 Tolerância de E. grandis a diferentes agentes seletivos........................ 65

4.3.5 Avaliação da eficiência de transformação de E. grandis, E. urophylla e do híbrido entre ambos..................................................................... $\quad 70$

4.3.6 Seleção, regeneração e obtenção de plantas transgênicas do híbrido $E$.

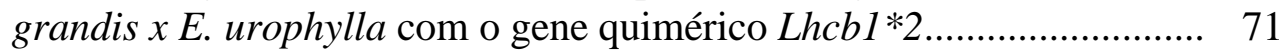

4.3.7 Seleção, regeneração e obtenção de plantas transgênicas de E. grandis com o gene marcador uidA............................................................ 73

4.4 Conclusões........................................................................... 75

5 CONCLUSÕES GERAIS................................................................. 76

REFERÊNCIAS BIBLIOGRÁFICAS................................................... 77 


\section{ABREVIATURAS E SÍMBLOS}

BA

GUS

MS

DNA

CaMV35S

TDZ

ANA

IBA

MB

MM

MA

ME

LHCB $1 * 2$

DO

Rbcs

nptII

rpm

$\mu \mathrm{M}$

s.

$\mu \mathrm{m}$

mg. $\mathrm{L}^{-1}$

$\mu$. E. $\mathrm{m}^{-2} \cdot \mathrm{s}^{-1}$ 6-benzil adenina

$\beta$-glucuronidase

Murashige \& Skoog (1962);

Ácido desoxirribonucléico

Vírus do mosaico da couve-flor

1-phenil-3-(1,2,3-tidiazol-5-il) urea (tidiazuron)

Ácido naphtaleno acético

Ácido idole butirico

Meio básico

Meio de multiplicação

Meio de alongamento

Meio de enraizamento

Chlorophyll a/b binding protein

Densidade ótica

Ribulose-1,5-bisfosfato carboxilase

Gene da neomicina fosfotransferase

Rotações por minuto

Micromolar

Segundos

Micrometro

Miligramas por litro

Micro Einstein por metro quadrado por segundo 


\title{
TRANSFORMAÇÃO GENÉTICA DE Eucalyptus grandis E DO HÍBRIDO $E$. grandis $x$ E. urophylla VIA Agrobacterium
}

\author{
Autor: ESTEBAN ROBERTO GONZÁLEZ
}

Orientador: PROF. DR. CARLOS ALBERTO LABATE

\section{RESUMO}

A produção de papel e celulose representa um importante componente do setor industrial brasileiro, com perspectivas a expandir-se nos próximos anos, sendo o Brasil o principal produtor de celulose a partir de eucalipto. A técnica de transformação genética pode contribuir significativamente para introduzir caracteres de interesse econômico que permitam: aumentar a produtividade da cultura, resistência a doenças e melhorar a qualidade da madeira. Os sistemas de transformação genética requerem um sistema de regeneração de plantas in vitro eficiente associado a um sistema de integração estável do transgene ao genoma das mesmas. Por este motivo o trabalho foi dividido em duas etapas. A primeira parte foi orientada para o desenvolvimento de um sistema de regeneração eficiente e reproduzível por organogênese indireta tanto para E. grandis como para o híbrido E. grandis $x$ E. urophylla. Foram realizados experimentos para avaliar-se o efeito dos diferentes tipos de explantes, genótipos, concentrações de reguladores de crescimento e taxa regenerativa de diferentes clones. A regeneração de cotilédones e folhas de plântulas apresentou uma eficiência de $30 \%$ e $25 \%$, 
respectivamente. Além destes sistemas, o protocolo de regeneração a partir de folhas de clones comerciais de E. grandis mostrou-se bastante eficiente. Na segunda parte do trabalho desenvolveu-se a metodologia de transformação genética de $E$. grandis e $E$. grandis $x$ E. urophylla, via Agrobacterium tumefaciens. O efeito de diferentes tempos de pré-cultivo dos explantes, tempo de sonicação, influência dos meios de co-cultivo e dos agentes seletivos, foram avaliados. As sementes pré-cultivadas durante 2 e 15 dias apresentaram as maiores porcentagens de expressão da $\beta$-glucuronidase (GUS) (21,7 e $37,4 \%$, respectivamente), quando sonicadas. As sementes pré-cultivadas por 2 dias apresentaram mais de $90 \%$ das áreas transformadas localizadas nos cotilédones e no colo. Já as sementes pré-tratadas por 15 e 17 dias apresentaram $60 \%$ das áreas de transformação localizadas no primeiro par de folhas. A condição mais adequada para a transformação de cotilédones foi a sonicação por $120 \mathrm{~s}$, de sementes pré-cultivadas por 2 dias, sendo o melhor meio de co-cultivo o MS. Plantas transgênicas de E. grandis e $E$. grandis $x$ E. urophylla foram obtidas, abrindo assim uma grande perspectiva na área de melhoramento do eucalipto, com a introdução das técnicas de transformação gênica. 


\title{
GENETIC TRANSFORMATION OF Eucalyptus grandis AND OF THE HYBRID E. grandis $x$ E. urophylla VIA Agrobacterium
}

\author{
Author: ESTEBAN ROBERTO GONZÁLEZ \\ Adviser: PROF. DR. CARLOS ALBERTO LABATE
}

\section{SUMMARY}

The pulp and paper industry is an important sector of Brazilian industry, showing good perspectives of expansion, once Brazil is the main cellulose producer from Eucalyptus. Genetic transformation may contribute to increase productivity by the introduction of desirable traits, such as pest resistance and improvement of wood quality. However, the prerequisite for the success of the transformation strategy is the establishment of an efficient, in vitro, regeneration system. The recovery of transgenic plants is only possible from cells that respond to both processes: the integration of the transgene and also the plant regeneration. Hence, this work was divided in two phases. The first study was carried out to develop an efficient and reproducible regeneration system by indirect organogenesis of E. grandis and the hybrid E. grandis $x$ E. urophylla. The experiments were organized to evaluate the effect of the different seedling explants, genotypes, hormonal concentration and regenerative rate of clonal material. The regeneration efficiency of cotyledons and leaves of seedling explants was around $30 \%$ and $25 \%$, respectively. In addition, an efficient regeneration protocol of Eucalyptus 
grandis was developed which uses leaf explants from clonal plants. In the second study the procedure for genetic transformation of E. grandis and E. grandis $X$ E. urophylla using Agrobacterium is described. Several experimental parameters were evaluated such as the length of precultivation, the sonication effect, the cocultivation media and the selective agents. Germinating seeds of 2 and 15 days had the highest percentage of $\beta$ glucuronidase (GUS) expression (21.7\% and 37.4\%, respectively), when sonicated. Germinating seeds imbibed for 2 days showed over $90 \%$ of the blue sectors localized in cotyledons and in the intersection of the hypocotyls and roots, whereas, seedlings that had germinated for 15-17 days had an average of $60 \%$ of the transformed sectors localized in the first pair of leaves. The best condition for an efficient genetic transformation was 2-day precultivation, associated with 120-s sonication and MS media for cocultivation. Transgenic plants of E. grandis and E. grandis $x$ E. urophylla were obtained by this method, opening an important perspective for the breeding of Eucalyptus through genetic transformation techniques. 


\section{INTRODUÇÃ̃o}

As espécies do gênero Eucalyptus não ocorrem naturalmente no Brasil. Os exemplares mais antigos de eucalipto encontrados no Brasil foram plantados pelo Imperador D. Pedro I no Jardim Botânico do Rio de Janeiro, em 1825. A expansão em larga escala do cultivo de eucalipto teve inicio em 1903, na Companhia Paulista de Estradas de Ferro. A principal espécie plantada atualmente no país é E. grandis e seus híbridos, sendo que hoje, estima-se que a área plantada com Eucalyptus, seja de cerca 1.500.000 hectares. Os principais estados produtores são, Minas Gerais, São Paulo, Bahia e Rio Grande do Sul (SBS Silvicultura, 2000). As principais razões do uso extensivo de Eucalyptus em reflorestamentos comerciais em várias partes do mundo, se deve ao seu rápido crescimento (média de $45 \mathrm{~m}^{3} / \mathrm{ha} / \mathrm{ano}$ em plantios clonais), e à produção de fibras e polpa de madeira de alta qualidade. Além disso, também são relevantes o baixo custo e o curto período de corte (5-7 anos), fatores que permitem até 3 rotações sucessivas e econômicas, com ciclo de até 21 anos (Ho et al., 1998).

As espécies de eucalipto apresentam excelente potencial para a produção de madeira em função de sua diversidade, adaptabilidade, alta produtividade e características físico-mecânicas, que permitem inúmeras utilizações como matéria-prima para produção de papel e celulose, marcenaria (serraria e madeira processada), caixotaria, estruturas para construção civil, dormentes, moirões, postes, lenha e carvão vegetal, indústria química e farmacêutica, como também na apicultura e ornamentação. 
Do ponto de vista ambiental, o uso de madeira reflorestada contribui significativamente para a proteção e conservação dos recursos naturais existentes, preservando-se assim, áreas de mata nativa já escassas e prevenindo-se também a extinção de espécies consideradas nobres, geralmente de madeira dura e crescimento muito lento, suprindo dessa forma, o mercado com madeira para fins industriais e geração de energia. A devastação anual de florestas naturais é estimada em cerca de 4 milhões de hectares na América Latina, sendo o Brasil responsável por 35\% deste valor. Parte desta área é convertida para culturas agrícolas, mas a grande maioria é transformada em pasto para criação extensiva de gado de corte (Ferreira, 1979).

A eucaliptocultura também é indicada para ocupação de áreas degradadas pela ação antrópica que são impróprias à agricultura. As raízes profundas do eucalipto são capazes de buscar nas camadas inferiores do solo, nutrientes minerais que já estão fora do alcance de raízes superficiais de outras culturas, podendo, assim, controlar a erosão do solo (SBS, Silvicultura, 2000).

A partir de projeções de mudanças climáticas causadas pelo efeito estufa, provocado pelo aumento da concentração de gás carbônico na atmosfera, discute-se a possibilidade de que programas maciços de megareflorestamento com espécies de crescimento rápido possam propiciar uma participação decisiva no controle do aquecimento global, através de sua ação no seqüestro de gás carbônico (Trexler, 1989).

As técnicas de manejo florestal complementadas pelo melhoramento genético, geram povoamentos mais produtivos, em menor período de tempo, adaptados a diferentes regiões e mais condizentes às qualidades necessárias para os diferentes usos industriais da madeira. A estratégia de melhoramento genético do eucalipto baseia-se atualmente no melhoramento das espécies puras, do ponto de vista tipológico e na exploração de híbridos interespecíficos (Bertolucci et al., 1995). Na primeira, procura-se aumentar a produção sem reduzir perigosamente a variabilidade natural. $\mathrm{Na}$ segunda 
estratégia, procura-se obter ganho genético máximo em uma única geração, utilizando-se todos os níveis da variabilidade entre e dentro de espécies.

Uma das formas para alcançar rapidamente ganhos de produtividade desejados, em menor espaço de tempo, é através da propagação vegetativa, pela qual se obtêm clones, o que permite a manutenção de características superiores por serem estes, geneticamente uniforme. Em geral, o critério de seleção de árvores superiores, visando obter alta produtividade, a custos competitivos para geração de clones adaptados às condições locais, baseia-se na avaliação de caracteres silviculturais.

A produção de papel e celulose é um componente importante do setor industrial brasileiro, com perspectivas de expansão para os próximos anos. O Brasil apresentou forte crescimento desse setor, tornando-se o principal produtor de celulose a partir do eucalipto como matéria-prima. No ano de 2001 foram produzidas 7,4 milhões de toneladas de celulose e pasta, e 7,3 milhões de toneladas de papel, com faturamento total de US\$ 6,7 bilhões (Bracelpa, 2002). Desse total, cerca de US\$ 2,6 bilhões foram obtidos com exportações. O setor de celulose papel conta com investimentos em fase de execução da ordem de US\$ 2 bilhões, sendo em bõa parte com apoio financiero de BNDES. Com entrada em operação de novas unidades prevista para 2002 e 2003, haverá uma produção adicional de mais de 1,3 milhão de toneladas à produção atual de celulose branqueada de eucalipto. No segmento de papel os investimentos vêm sendo realizados no desenvolvimento tecnológico de processos e produtos de maior valor agregado (Bracelpa, 2002).

As técnicas da biotecnologia aliadas ao melhoramento convencional, podem contribuir significativamente para um aumento do desenvolvimento vegetativo e da biomassa das plantas. No entanto, um programa que visa obter ganhos genéticos em espécies florestais, envolve pelo menos 15 anos em razão do longo ciclo vegetativo dessa cultura. A introdução de genes de interesse, via transformação genética, representa um importante instrumento para atingirmos esses objetivos em curto período de tempo. Através da transformação genética pode-se incorporar genes desejáveis com 
características de interesse econômico, como alta produção de biomassa, resistência à doenças e alta qualidade da madeira, com a mínima alteração do genoma.

O presente trabalho tem como objetivo o desenvolvimento de um sistema de transformação genética de E. grandis e E. grandis $x$ E. urophylla que permita a introdução de genes de interesse. Todo sistema de transformação genética requer sistemas de regeneração in vitro que permitam a recuperação de plantas a partir de células transgênicas. Assim, a primeira parte do trabalho resultou no desenvolvimento de um sistema eficiente e reproduzível de regeneração por organogênese indireta e a segunda, apresenta o desenvolvimento de um sistema de obtenção de plantas transgênicas utilizando-se a técnica de inoculação com Agrobacterium, assistida por sonicação de sementes em germinação. 


\section{REVISÃO DE LITERATURA}

\subsection{O gênero Eucalyptus}

Eucalyptus é um gênero da Família Myrtaceae, composto por arbustos e árvores de grande porte. Existem cerca de 500 a 700 espécies de eucalipto descritas, além de muitas subespécies e alguns híbridos naturais (Bertolucci et al., 1995). São também notórias as variedades fenotípicas intraespecíficas decorrentes de condições ambientais ou hibridação. Quanto mais espécies são cultivadas, mais hibridação ocorre entre as espécies cultivadas próximas umas às outras, resultando em híbridos de parentesco indeterminado. Considerando todos estes fatores, torna-se difícil a classificação dos eucaliptos.

O gênero está subdividido, taxonomicamente, em 8 sub-gêneros informais, segundo Pryor (1976), obtidos pela manipulação bem sucedida de híbridos em cada um dos grupos. O Sub-gênero Symphyomyrtus é o grupo que apresenta a maioria das espécies cultivadas no mundo. Este sub-gênero apresenta 9 seções entre as quais, 3 contêm praticamente todas as espécies mais cultivadas como exóticas:

Seção Transversaria: E. grandis, E. saligna, E. urophylla;

Seção Exsertaria: E. camaldulensis, E. exserta, E. tereticornis;

Seção Maidenaria: E. globulus, E. viminalis. 
As flores do eucalipto são morfologicamente bissexuadas (hermafroditas). Existem evidências de que em Eucalyptus ocorre tanto fecundação cruzada como autofecundação (Pryor, 1976). Estudos posteriores confirmaram as observações de Pryor em relação a uma ampla faixa de padrões de cruzamento, incluindo os dois extremos, ou seja, desde autofecundação causada por cleistogamia (Venkatesh et al., 1973), até fecundação cruzada obrigatória, devido à autoincompatibilidade (Pryor, 1957), macho esterilidade (Davis, 1969) ou esterilidade feminina (Carr et al., 1971). Nas populações naturais, as espécies cultivadas de eucalipto exibem um sistema de cruzamento misto, mas predominantemente alógamo. Análises de isoenzimas de sementes de uma série de espécies resultaram em uma taxa de alogamia estimada, (t) da ordem de 0,75 (Moran \& Bell, 1983).

A análise cariotípica de 108 espécies do gênero Eucalyptus indica que 95 espécies apresentam número básico de cromossomos $2 n=22$ da mesma forma que a maioria dos gêneros da família Myrtaceae. As demais 13 espécies apresentam 2n=24, sendo que, entre estas, somente E. cladocalyx é plantada com finalidade de produção de madeira (Eldridge et al., 1994). Os cromossomos neste gênero são extremamente pequenos o que dificulta uma contagem acurada (Ruggeri, 1961) e não há repetições que possam confirmar valores de $2 n=24$. Estimativas do conteúdo de DNA nuclear para as espécies examinadas por (Grattapaglia \& Bradshaw, 1994) variaram entre 0,77 pg para E. citriodora e 1,47 pg para E. saligna o que corresponde a um genoma haplóide de 370700 mega pares de bases.

As espécies do gênero tiveram sua origem na Austrália e regiões próximas como Timor, Indonésia, Papua Nova Guiné, Molucas, Irian Jaya e sul das Filipinas (Figura 1), confinadas essencialmente a um único continente, na faixa compreendida entre latitudes $9^{\circ} \mathrm{N}$ e $44^{\circ} \mathrm{S}$ (Eldridge et al., 1994). Encontram-se amplamente espalhadas na natureza em altitudes que variam de 30 até 1000 metros. 


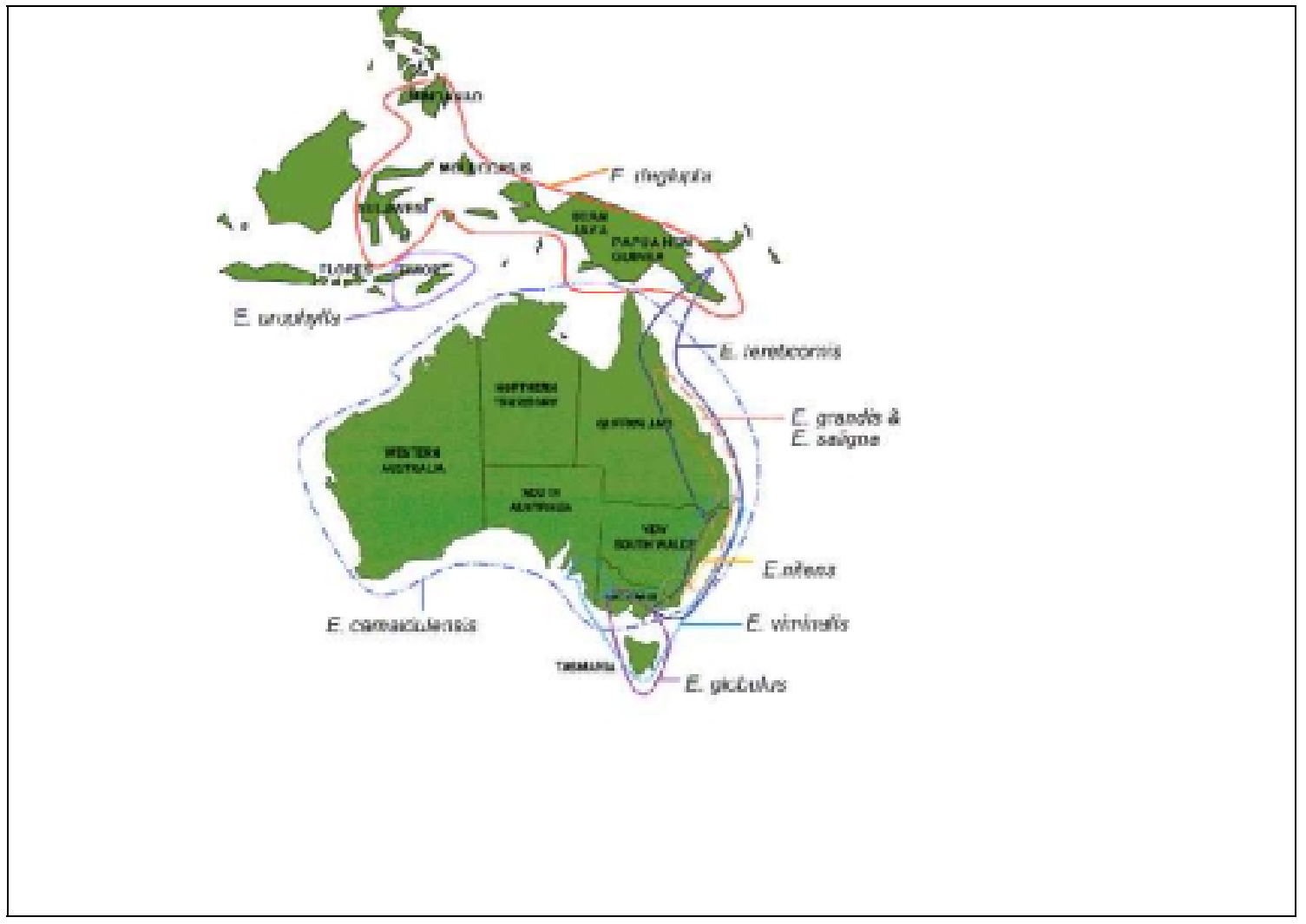

Figura 1 - Limite de distribuição natural do gênero Eucalyptus.

O Eucalipto é plantado, atualmente, na maioria das regiões de clima tropical e subtropical do mundo, entre as latitudes de $40^{\circ} \mathrm{N}$ e $45^{\circ} \mathrm{S}$, pois é um gênero que possui espécies adaptadas a diversas condições de clima e solo. Os maiores produtores mundiais de eucalipto são Brasil, Índia, África do Sul, Portugal, Angola, Espanha e China. Entre as centenas de espécies do gênero Eucalyptus, cerca de trinta têm mostrado potencial para cultivos de alta produtividade. Entretanto, calcula-se que apenas dez espécies são utilizadas nos $4 \times 10^{6}$ hectares de área mundial ocupados pela eucaliptocultura. 


\subsection{Transformação genética de plantas}

Transformação genética é definida como sendo a introdução controlada de ácidos nucléicos, em um genoma receptor (Potrycus, 1991). Ao lado da hibridação somática, é uma das técnicas de transferência, não sexuada, de genes em plantas. Enquanto na hibridação somática os protoplastos de dois indivíduos se fundem, levando à mistura de genomas (Lindsey, 1992), a transformação é um processo mais controlado. Nele, apenas um fragmento definido de ácido desoxirribonucléico (DNA), que possui genes específicos, é introduzido no genoma do hospedeiro, ou genoma receptor, devendo ser a ele integrado.

Para a aplicação das técnicas de transformação na agricultura, é necessário que células de tecidos transformados regenerem plantas que expressem os genes introduzidos. Entretanto, a transformação genética requer um sistema de regeneração in vitro que permita dispor do maior número de células com capacidade de regeneração (Potrycus, 1991), além de um sistema de transferência gênica que permita a integração do transgene no maior número de células possíveis associado a um sistema de seleção que permita diferenciar as células transformadas.

\subsubsection{Regeneração in vitro}

A aplicação de novas tecnologias associadas ao melhoramento genético convencional, tais como mutagênese in vitro, seleção in vitro, variação somaclonal, micropropagação e transformação genética, requerem protocolos que permitam regenerar plantas a partir de grupos de células vegetais, explorando dessa forma a totipotência da

mesma. As técnicas de transformação genética geralmente levam à transferência do 
DNA de interesse para umas poucas células. Assim, um pré-requisito essencial é um protocolo eficiente de regeneração de plantas por cultura de tecidos (McCown \& Sellmer, 1987).

Num contexto mais geral, trata-se de um método no qual pequenos fragmentos de um determinado tecido vegetal (denominado explante) são isolados de uma espécie vegetal, desinfestados e cultivados asceticamente em meio de cultura contendo sais minerais, vitaminas e fonte de carbono em quantidades necessárias ao desenvolvimento vegetal. As quantidades e tipos de fitorreguladores vegetais presentes no meio de cultura variam, conforme o objetivo e a fase do cultivo e também conforme à espécie cultivada. Os avanços nessa área têm ampliado as perspectivas de aplicações em diversos campos da biotecnologia de plantas (Davies, 1995).

Há uma interação grande entre a biologia molecular, cultura de tecidos e a produção de novos genótipos. A biologia molecular contribui com a identificação, isolamento e modificação do gene, que por sua vez é transferido para cultura de tecidos via protoplastos, células, calos e cultura de embriões. As plantas regeneradas desses processos, são caracterizadas, selecionadas e desenvolvem assim novos cultivares com ajuda da genética. A aplicação da cultura de tecidos na propagação e melhoramento de plantas, envolve diversas técnicas como: cultura de embriões, cultura de meristemas, micropropagação, embriogênese somática, seleção in vitro, cultura de anteras e cultura de protoplastos (McCown \& Sellmer, 1987).

A cultura de tecidos vegetais é uma técnica através da qual pequenos pedaços selecionados de planta, denominados explantes, são cultivados em meio artificial, contendo os nutrientes orgânicos e inorgânicos necessários ao crescimento e desenvolvimento vegetal, sob condições assépticas (Mccown \& Sellmer 1987). Esta técnica baseia-se na totipotência ou competência celular, que é a capacidade que as células possuem de regenerar a planta inteira. No entanto, o sucesso de um sistema de regeneração depende, do controle de um grande número de variáveis. Ao contrário do 
que freqüentemente se acredita, por exemplo, a composição de um meio de cultura, não é a variável determinante do sucesso da micropropagação. A função dos vários componentes utilizados nos meios de cultura é suficientemente conhecida e a receptibilidade de uma determinada formulação é praticamente absoluta (McCown \& Sellmer, 1987).

Nos tecidos em cultura, o controle da organogênese é feito através da introdução de sinais e substratos diversos (Handro \& Floh, 1990). A retirada de um fragmento de tecidos de um organismo íntegro e sua colocação em um meio de cultura que contém nutrientes e reguladores de crescimento traz como consequiência a liberação de suas células do controle a que estavam submetidos nesse organismo, expondo-as a uma nova condição, onde a capacidade de divisão pode ser readquirida (desdiferenciação) e o genoma pode expressar-se de novas formas, conduzindo-as a novos padrões de diferenciação. Esses eventos podem, de diversas maneiras, levar à formação de novas estruturas organizadas, num processo morfogenético ou organogenético (Handro \& Floh, 1990).

Os reguladores de crescimento vegetal são compostos de ocorrência natural, substâncias orgânicas com influência na morfologia e fisiologia da planta e que atuam em baixas concentrações $\left(10^{-4} \mathrm{M}\right.$ a $\left.10^{-3} \mathrm{M}\right)$. Estes compostos promovem, inibem ou modificam processos metabólicos das plantas. Os reguladores vegetais têm a mesma função, porém são exógenos. O termo regulador de crescimento é de origem grega e em fisiologia de animais, significa mensageiro químico. $\mathrm{O}$ uso original em fisiologia de plantas é derivado da concepção de regulador de crescimento em mamíferos (Davies, 1995).

Em cultura de tecidos vegetais, os fatores a serem considerados podem ser agrupados em cinco amplas categorias (McCown \& Sellmer, 1987):

- genótipo, fonte e histórico; 
- composição do meio de cultura;

- ambiente (condições de luminosidade, temperatura, umidade e pressão, frasco de cultura);

- tempo (períodos de sub-cultivo);

- interações entre e dentro dos fatores acima mencionados.

O sucesso do processo de regeneração vegetal, através da cultura de tecidos, é bastante influenciado pela natureza do meio de cultura utilizado. Presume-se que este meio deva conter todas as substâncias que os tecidos normalmente obtêm do floema e do xilema. Os nutrientes essenciais incluem sais inorgânicos, fonte de carbono e energia, vitaminas e reguladores de crescimento. Outros componentes, incluindo compostos nitrogenados orgânicos, ácidos orgânicos e substâncias complexas, podem ser importantes, mas são opcionais (Gamborg \& Shyluk, 1981).

Do ponto de vista, os reguladores de crescimento influenciam processos de desenvolvimento através da sua interação com receptores dentro da célula vegetal. Os reguladores de crescimento vegetais atuam em muitos processos fisiológicos pela ativação ou repressão de certos grupos de genes, influenciando, a taxa e a direção da expansão, bem como, a taxa de divisão celular. Estes efeitos na célula são regulados através de vias de respostas bioquímicas complexas, freqüentemente envolvendo mensageiros secundários (Davies, 1995).

Os avanços das pesquisas sobre a função dos reguladores de crescimento e a bioquímica do DNA, têm possibilitado a manipulação genética de plantas em direções específicas. Um dos mais importantes procedimentos da biotecnologia é a cultura de tecidos, para e regeneração de plantas. Potencialmente, qualquer genótipo pode ser cultivado e regenerado se conhecermos as condições adequadas de cultura. Entretanto, as características gerais da resposta à cultura de tecidos é uma condição herdável (Bingham et al., 1975; Kielly \& Brouwley, 1992). 
Em princípio a regeneração de tecidos vegetais pode acontecer através de duas vias principais, organogênese e embriogênese somática, que freqüentemente, podem distinguir-se claramente.

\section{Organogênese}

A organogênese geralmente é ativada pela otimização das concentrações de auxinas e citocininas no meio de cultura, relacionada à diferenciação de órgãos. Embora os resultados obtidos para um cultivar não possam ser extrapolados para um outro ou à outra espécie. Geralmente quando a concentração de auxinas é alta, favorece-se a formação de raízes. Já a alta concentração de citocininas, estimula a formação de tecidos da parte aérea. Se os órgãos são desenvolvidos a partir de células existentes no explante original, a organogênese é do tipo direta, mas se os órgãos se desenvolvem a partir de células ou grupos de células formadas durante a passagem pelo estádio de calo, a organogênese é do tipo indireta (Kang \& Chun, 1997).

\section{Embriogênese somática}

A embriogênese somática, freqüentemente induzida pelo tratamento com auxinas, resulta na formação de estruturas embrionárias não zigóticas, a partir de uma ou várias células. Na ausência de auxina no meio de cultura, a morfogênese continua a dar origem a um embrião maduro que em meio adequado, germinará sem a necessidade de passar antes por um período de dormência. Este processo não requer fusão gamética (embriogênese direta), podendo compreender um estádio intermediário de formação de calo, denominado embriogênese indireta (Park \& Son, 1997).

Embriões somáticos podem ser obtidos a partir de células somáticas originárias de calos, suspensão ou cultura de protoplastos. Se há células somáticas em calos, estes 
são considerados como sendo equivalentes ou similares a zigotos, então, os estádios iniciais de desenvolvimento de embriões somáticos, podem ser descritos como similares aos estádios de desenvolvimento de embriões zigóticos (Park \& Son, 1997).

Muitos estudos sobre embriogênese somática em Eucalyptus são encontrados na literatura, mas só quatro espécies foram capazes de regenerar plantas: E. citriodora (Muralidharam et al., 1989), E. grandis (Watt et al., 1991), Eucalyptus "Leichow N 1"(Ouyang et al., 1981) e E. dunnii (Termignoni et al., 1996), entretanto, os protocolos de regeneração são muito dependentes do genótipo e de difícil reprodutibilidade.

\subsubsection{Transferência do DNA}

A transferência gênica pode ser realizada por vetores bacterianos ou virais (vetores biológicos), ou pela transferência direta (métodos físicos). A escolha do método de transferência vai depender da espécie vegetal, do sistema de regeneração in vitro e da susceptibilidade do material ao agente de transferência.

\section{Sistemas físicos}

A maioria das monocotiledôneas, incluindo muitos cereais apresentam resistência à infeção com A. tumefaciens, o que dificulta a transformação por esta via. Devido a isso, torna-se necessário desenvolver-se métodos alternativos de transferência de genes para essas espécies (Potrykus et al., 1985).

Dentre os métodos desenvolvidos, podemos mencionar a microinjeção (Neuhaus \& Spangenberg, 1990), a transformação de protoplastos por polietilenoglicol (Songstad et 
al., 1995) ou por eletroporação (Barros \& Carneiro, 1998), e também, o bombardeamento de microprojéteis (Klein et al., 1987).

A técnica de biobalística ou bombardeamento com microprojéteis, é uma das mais bem sucedidas para a transferência direta de genes. A mesma consiste da aceleração de microprojéteis, geralmente de ouro ou tungstênio de 1 a $4 \mu \mathrm{m}$ de diâmetro, a uma velocidade de 300 a $600 \mathrm{~m} / \mathrm{s}$, suficiente para penetrar as paredes e membranas celulares. Estes projéteis carregam moléculas de DNA precipitadas na sua superfície, que são liberadas, sendo que algumas atingem o núcleo da célula vegetal e outras em baixa freqüência, conseguem integrar-se de forma aleatória no genoma (Klein et al., 1987).

As moléculas simples de DNA, utilizadas para transformação genética de forma direta, consistem de um módulo pequeno de expressão, com marcadores selecionáveis, clonados a plasmídeos que possuem uma origem de replicação de E. coli e um gene marcador de resistência a um determinado antibiótico, para a seleção das bactérias que levam o inserto. Os vetores de transformação genética geralmente possuem um tamanho de 4 a $7 \mathrm{~Kb}$. Sendo que plasmídeos de maior tamanho, geralmente não apresentam estabilidade em experimentos de transferência genética direta (Vasil et al., 1991). Dentre os métodos de transformação genética direta para Eucalyptus, excluem-se os baseados em regeneração de protoplastos, por não existir protocolo eficiente de regeneração de plantas por esta via.

\section{Sistemas biológicos}

Alguns vírus como caulimovírus e geminivírus, têm a capacidade de infectar um amplo espectro de espécies vegetais, inclusive monocotiledôneas. Embora estes vírus não sejam utilizados extensivamente como vetores, são de grande importância no desenvolvimento da biologia molecular. Deles foram isolados promotores, entre outras seqüências importantes, como o promotor constitutivo, $35 \mathrm{~S}$ do vírus do mosaico da 
couve-flor (CaMV35S), de grande utilidade nas construções gênicas utilizadas em experimentos de transformação (Gardner, 1983).

A Agrobacterium tumefaciens é uma bactéria Gram negativa de solo, que vive em associação com a rizosfera das plantas (Ream, 1989). As Agrobactérias são hóspedes de vários plasmídeos e fagos. Seus plasmídeos Ti e Ri são exclusivos das espécies tumefaciens e rhizogenes, respectivamente e conferem às mesmas uma capacidade patogênica capaz de alterar o metabolismo e desenvolvimento de células da planta, que resulta na doença conhecida como "Galha da Coroa" no caso de Agrobacterium tumefaciens e síndrome das raízes em cabeleira, no caso de Agrobacterium rhizogenes (Lutova et al., 1998). Este processo de colonização da planta requer a transferência de genes dos plasmídeos para o genoma da planta. Esse processo resulta no desenvolvimento de um tumor na planta, que representa um mecanismo de engenharia genética natural, de transferência de genes entre reinos diferentes. Este processo é determinado pela presença do plasmídeo Ti ou Ri de A. tumefaciens, e A. rhizogenes, respectivamente, de aproximadamente 200-250 kilopares de bases (Kb) (Ream, 1989). O processo de transferência depende de duas regiões essenciais: o T-DNA, região do plasmídeo que é transferida e integrada ao núcleo da célula hospedeira, e a região vir, composta pelos genes que codificam proteínas essenciais à transferência.

A região do T-DNA é delimitada por duas regiões ou bordas que são as únicas seqüências do T-DNA requeridas para a transferência. Durante à infeção, a $A$ tumefaciens em contato com os compostos fenólicos, liberados pela planta nos locais de ferimento, ativa os genes de virulência (virA, $B, C, D$ e $E$ ) presentes no plasmídeo Ti. A acetoseringona é um dos compostos fenólicos que participam ativamente na indução dos genes de virulência e foi identificada e isolada de tabaco, (Boltron et al., 1986). Na presença dos compostos fenólicos liberados na região do ferimento, o produto protéico do gene virA, uma proteína quinase de transmembrana, ativa o produto do gene virG, um fator de transcrição, que por sua vez, ativa os outros genes de virulência (vir B, $C, D$ e $E$ ) (Gelvin et al., 2000). 
Após a indução dos genes de virulência, a fita simples nas bordas do T-DNA, são cortadas por enzimas de restrição produzidas pelo produto protéico do gene virD. Esse, desencadeia o aparecimento de fitas simples e lineares de DNA correspondentes ao TDNA. Estas fitas associam-se às proteínas do gene vir $E$ que confere estabilidade ao processo, e à proteína VirD2 que se une covalentemente à extremidade 5' do T-DNA. Este complexo de proteínas e DNA é transferido para o citoplasma da célula vegetal, onde regiões de sinalização de direcionamento nuclear das proteínas VirE2 e VirD2 orientam o complexo aos poros nucleares (Gelvin et al., 2000).

Uma vez que o complexo encontra-se no núcleo, a integração do T-DNA, no genoma, envolve proteínas que participam do processo de reparo, recombinação e síntese de DNA (Ohba et al., 1995). O sistema de integração do T-DNA não é conhecido, entretanto a inserção parece ser ao acaso, havendo uma preferência por regiões transcricionalmente ativas (Koncz et al., 1992).

A região do T-DNA possui genes que codificam também reguladores de crescimento vegetais, uma vez que a expressão dos mesmos, nas células vegetais, resultam na formação de tumores. Outros genes também presentes nessa região, são responsáveis pela síntese e secreção de aminoaçúcares (opinas) utilizadas pelas bactérias, como fonte de carbono e nitrogênio (Lutova et al., 1998).

Essas bactérias são utilizadas como vetores de transformação. Os genes presentes na região central do T-DNA, não são essenciais ao processo de transferência gênica e podem ser eliminados e substituídos por genes de interesse clonados a genes marcadores que possibilitam selecionar células transformadas em meios de cultura específicos. Este procedimento permite desenvolver vetores de transferência gênica a uma ampla variedade de espécies dicotiledôneas, hospedeiras naturais dessa bactéria (Caplan et al., 1983).

O uso de A. tumefaciens como vetor de transferência genética proporciona geralmente padrões simples de integração (Block, 1993). Embora alguns trabalhos 
mostrem a integração de múltiplas cópias (De Neve et al., 1997), transformantes contendo cópias únicas são facilmente recuperados (Vergunst \& Hooykaas, 1999). Por outro lado, os métodos de transferência genética direta, geralmente resultam na integração de múltiplas cópias, gerando silenciamento e instabilidade de expressão genética (Vergunst \& Hooykaas, 1999).

\subsubsection{Seleção de tecidos transgênicos}

Nos experimentos de transformação, acrescenta-se ao meio de cultivo um agente seletivo em uma concentração definida, que proporciona uma vantagem seletiva às células que contêm o gene marcador, sobre as células que não o possuem. $O$ protocolo não só deve assegurar a proliferação celular e o desenvolvimento de estruturas organizadas, como também, permitir a recuperação de plantas transgênicas (Wilmink \& Dons, 1993).

Os principais fatores a serem considerados na escolha de um determinado gene marcador são: a) a expressão do mesmo não deve interferir no metabolismo normal das células transformadas, b) seu produto deve proteger de modo efetivo as células transformadas, das propriedades inibitórias de crescimento do agente seletivo, além de ter uma boa difusão nos tecidos, de forma a permitir uma distinção fenotípica clara entre as células transformadas e as não transformadas, c) a exposição do explante transgênico ao agente seletivo, não deve afetar seu subsequente crescimento e regeneração em plantas inteiras e férteis (Potrycus \& Spangenber, 1995).

Dentre os genes marcadores que conferem resistência a um determinado antibiótico ou herbicida, estão:

a) aqueles que produzem uma enzima funcional a qual não é reconhecida pelo 
agente seletivo (por exemplo, o gene bar que confere resistência ao herbicida Basta, tem sido utilizado na obtenção de plantas transgênicas de diferentes espécies) (Wilmink \& Dons, 1993).

b) aqueles que produzem um produto que permite a desintoxicação e eliminação do agente seletivo (por exemplo, genes de resistência aos antibióticos cloranfenicol, neomicina e higromicina) (De Block et al., 1987). Na maioria dos casos, o gene codifica uma enzima que inativa o agente seletivo por transferência de grupos fosfatos (por exemplo, o gene neomicina-fosfotransferase, nptII) ou transacetilação (por exemplo, os genes cloranfenicol-acetil transferase, fosfinotricina-acetil transferase) (Wilmink \& Dons, 1993).

\subsection{Caracterização de plantas transgênicas}

\subsubsection{Coloração histoquímica da $\beta$-glucuronidase (GUS)}

O uso de genes que permitem diferenciar as células transgênicas por observação visual possibilita determinar variáveis associadas ao método de transformação genética, em experimentos pilotos. Um exemplo bastante conhecido é o gene uidA, que codifica a enzima $\beta$-glucuronidase (GUS), uma hidrolase de peso molecular de 68,2 kDa. Esse gene foi isolado por Jefferson et al. (1986), de um operón de Escherichia coli e é amplamente utilizado como gene marcador em plantas transgênicas. A ampla aceitação desse gene deve-se à simplicidade, rapidez e versatilidade do método de detecção da atividade enzimática e ao fato de que a maioria das plantas não apresenta atividade endógena significante. Além disso, a $\beta$-glucuronidase não requer cofator, é bastante estável, resistente a diversos solventes e ativa em uma ampla faixa de pH $(5,0$ a 9,0) (Tör 
et al., 1992). Entretanto, esse método apresenta algumas limitações, os ensaios são geralmente destrutivos, e algumas plantas ou tecidos, particularmente órgãos reprodutivos, apresentam atividade similar à $\beta$-glucuronidase (Plegt \& Bino, 1989; Hu et al., 1990; Hodal et al., 1992). Na maioria das vezes, essa atividade endógena é muito inferior à observada em plantas transgênicas, quando o gene está sob o controle de um promotor forte. A atividade GUS em tecidos não-transgênicos ou falsos positivos, também pode ser decorrente da presença de contaminações de fungos ou bactérias (Tör et al., 1992).

A expressão de GUS é considerada apenas como uma evidência de transformação, não sendo suficiente como prova definitiva da integração do gene uidA ao genoma da planta (Potrykus, 1991). Ainda assim, o ensaio de GUS é extremamente utilizado na identificação de tecidos de plantas, potencialmente transformados, que possam servir como parâmetros em estudos de otimização das condições de transferência de genes (Tör et al., 1992).

A atividade da $\beta$-glucuronidase pode ser detectada através do ensaio histoquímico, fluorimétrico, e espectrofotométrico (Lacorte 1998). O ensaio histoquímico é um método qualitativo, baseado na clivagem do substrato 5-bromo-4-cloro-3-indol- $\beta$-Dglucuronídeo (X-gluc) pela enzima $\beta$-glucuronidase (Jefferson, 1987). O produto desta reação, na presença de oxigênio, forma dímeros, resultando numa precipitação insolúvel de cor azul. É uma técnica de avaliação rápida que permite determinar a eficiência do processo de transferência após o co-cultivo do explante a ser transformado com a Agrobacterium. Em explantes inoculados com Agrobacterium a eficiência de transformação pode ser quantificada por meio da porcentagem de área dos tecidos que expressam GUS ou pelo número de pontos azuis (Jia et al., 1989; Novoa \& Coles, 1994 e Russell et al., 1992). 


\subsubsection{Detecção de transgenes por PCR}

A técnica de reação de polimerase em cadeia (Polimerase of chain reaction-PCR), pode gerar a partir de uma única molécula de DNA, bilhões de moléculas similares (Mullins \& Faloona, 1987). A reação de amplificação, catalisada pela enzima Taq-DNA polimerase, alonga um pequeno fragmento de DNA de fita simples, chamado oligonucleotídeo iniciador ou primer, quando este está ligado a uma fita molde ou template de DNA. O alongamento é feito pela adição, na extremidade 3', do iniciador do nucleotídeo complementar ao nucleotídeo da fita molde. O fragmento amplificado é o compreendido entre as duas extremidades 3', de um segmento dúplex, complementares aos dois iniciadores utilizados na reação. Os iniciadores são sintetizados artificialmente, tendo como base, uma seqüência complementar de nucleotídeos às seqüências que delimitam o fragmento a ser amplificado (Gama, 1998).

A amplificação inicia-se pela separação da fita molde de DNA através da elevação da temperatura de reação (desnaturação), normalmente $98^{\circ} \mathrm{C}$. A temperatura é então diminuída para que haja anelamento dos iniciadores com a fita molde de DNA, e a polimerase possa atuar, amplificando um novo fragmento. $\mathrm{O}$ fragmento produzido na reação anterior servirá então de molde para a reação seguinte. A reação de PCR envolve portanto, ciclos repetidos de desnaturação do DNA, anelamento dos iniciadores com suas sequiências complementares e a polimerização da fita complementar ao molde. Os segmentos de DNA são sintetizados de forma exponencial, pois a cada ciclo origina-se um novo segmento a partir do inicial e dos segmentos produzidos nos ciclos anteriores (Gama, 1998).

Uma das utilidades da técnicas de PCR é a análise da presença de transgene no material supostamente transformado em estádios precoces do desenvolvimento, enquanto outras técnicas são dificilmente aplicáveis devido a escassez de material disponível (Hamill et al., 1991). Os produtos de amplificação podem ser detectados por 
eletroforese em gel de agarose, corados com brometo de etídio (Sambrook et al., 1989). A amplificação de seqüências específicas do transgene utilizando-se a reação em cadeia da DNA polimerase, não é prova concludente de que o transgene (detectado com primers específicos) se encontre inserido de maneira estável no genoma analisado.

\subsubsection{Análise da Integração do DNA pela técnica de Southern Blot}

A técnica de Southern Blot permite detectar fragmentos de DNA específicos em amostras de composições complexas, como DNAs genômicos, descrito por Edwin M. Southern é até hoje utilizada, sem grandes alterações de sua primeira descrição (Southern, 1975).

Uma aplicação importante desta técnica está na confirmação da integração estável do transgene ao genoma do material transformado. O método consiste nas seguintes etapas: a) extração do DNA total da planta a ser analisada e digestão com enzimas de restrição específicas; b) os produtos da digestão são separados por tamanho, por eletroforese, em gel de agarose; c) o DNA fita dupla ainda no gel é desnaturado e transferido para uma membrana de nylon ou nitrocelulose; d) o DNA é fixado à essa membrana por temperatura de $80^{\circ} \mathrm{C}$ ou por irradiação ultravioleta; e) O DNA fixado à membrana é então hibridizado com uma sonda de DNA ou RNA complementar às sequiências homólogas à seqüência de interesse; f) a posição dos fragmentos com homologia é visualizada por auto-radiografia ou colorimetria, dependendo do tipo de sonda e da forma de detecção utilizadas (Romano, 1998).

A importância desta técnica em experimentos de transformação de plantas está na possibilidade de se provar de forma conclusiva, a integração de genes exógenos no genoma da mesma. A técnica de PCR pode ser utilizada para tal fim, no entanto, sua confiabilidade é menor, em virtude da sua alta sensibilidade que pode levar à aparição de 
falsos positivos por amplificações de quantidades mínimas de DNAs contaminantes contendo o gene analisado. Outra vantagem da técnica de Southern Blot é que dependendo da enzima utilizada pode servir para estimar o número de cópias do transgene analisado, e a presença de diferentes eventos de transformação, sendo que este tipo de informação não pode ser fornecida pela análise da reação de PCR devido à utilização de iniciadores (Primers) que amplificam somente as partes dos genes analisados (Romano, 1998). 


\section{SISTEMA DE REGENERAÇÃO DE PLANTAS A PARTIR DE TECIDOS DE PLÂNTUlas E CLONES COMERCIAIS DE Eucalyptus grandis E DE E. grandis $x$ E. urophylla}

\section{Resumo}

Os sistemas de transformação genética requerem protocolos de regeneração que permitam obter plantas transgênicas a partir de grupos de células transformadas. Neste trabalho foi desenvolvido um sistema de regeneração, eficiente e reproduzível, por organogênese indireta para E. grandis e E. grandis x E. urophylla. Além disso, foram avaliados diferentes genótipos, tipos de explantes e diferentes balanços de reguladores de crescimento. Para a realização dos experimentos utilizou-se o meio MS modificado contendo a metade dos macronutrientes e $3 \%$ de sacarose, além dos reguladores vegetais específicos para cada caso. O protocolo desenvolvido apresenta regeneração por organogênese indireta em 5 estádios: indução de calos, desenvolvimento de gemas, multiplicação de brotos, alongamento e enraizamento. A formação de calos e desenvolvimento de gemas foram induzidas em meios contendo diferentes balanços de tidiazuron (TDZ) e ácido nafitalenoacético (ANA). Para o meio de multiplicação de brotos utilizou-se 0,006 $\mu \mathrm{M}$ benziladenina (BA) e 0,88 $\mu \mathrm{M}$ ANA, para o alongamento; $0,44 \mu \mathrm{M}$ de BA e $1 \mu \mathrm{M}$ ácido idolbutírico (IBA) e para o enraizamento foi utilizado 4,9 $\mu \mathrm{M}$ IBA. A eficiência de regeneração de cotilédones e folhas de plântulas foi de $30 \%$ e $25 \%$, respectivamente. Além disso, quando utilizaram-se folhas de clones comerciais de 
E. grandis, a eficiência de regeneração foi genótipo dependente e o melhor resultado foi $48 \%$. A vantagem de trabalhar com material clonal é que os genótipos retém todas as características de interesse econômico dos clones selecionados. Este sistema apresenta boas características para ser utilizado na regeneração de plantas a partir de tecidos transgênicos. 


\section{PLANT REGENERATION SYSTEM FROM SEEDLINGS AND MICROPROPAGATED ÉLITE TREES IN Eucalyptus grandis AND E. grandis $x$ E. urophylla}

\section{Summary}

The introduction of foreign genes requires a plant regeneration procedure, which allows recovery of transgenic plants. Therefore, the objectives of this work were to develop an efficient and reproducible regeneration system by indirect organogenesis for E. grandis and E. grandis $x$ E. urophylla. The effect of seedling explants, genotypes, hormonal balance and clonal material was evaluated. The modified MS media used in the experiments contained half strength basal macro elements and $3 \%$ sucrose. The regeneration system has five culture stages, consisting of, calluses induction stage and adventitious bud induction, both in media containing a series of concentrations of thidiazuron and naphtalene acetic acid (NAA). The shoot formation medium is complemented with $0.006 \mu \mathrm{M}$ benzyl adenine (BA) and $0.88 \mu \mathrm{M}$ NAA. For the elongation stage the medium contained $0.44 \mu \mathrm{M}$ BA and $1 \mu \mathrm{M}$ idol butyric acid (IBA), and the rooting medium has $4.9 \mu \mathrm{M}$ IBA. The regeneration rate of cotyledons and leaves of seedling explants had an efficiency of $30 \%$ and $25 \%$, respectively. The use of leaves of micropropagated clones presented differences among genotypes. The best response of the three commercial clones evaluated was 48 per cent. The regeneration of cloned material has the advantage of retaining all traits of the original élite tree. 


\subsection{Introdução}

O sistema de transformação genética requer um protocolo de regeneração eficiente e que apresente reprodutibilidade. Neste processo pode ser utilizado tanto a organogênese como a embriogênese somática, pois a primeira permite a diferenciação de brotos e formação de raízes adventícias e a segunda, consiste no desenvolvimento e germinação de embriões somáticos para a posterior formação da planta.

A embriogênese somática tem sido obtida em várias espécies de Eucalyptus comercialmente importantes, partindo-se de explantes obtidos de plântulas (Muralidharan \& Mascareshas, 1987; Watt et al., 1991). No entanto, a organogênese tem-se mostrado mais eficiente na maioria das espécies. Alguns pesquisadores conseguiram obter regeneração de brotos a partir de órgãos juvenis de E. gunni (Adam et al., 1992), E. marginata, E. diversicolor (Bennett \& McComb, 1982), E. camaldulensis (Dialo \& Duhoux, 1984), E. globulus (Azmi et al., 1997; Bandyopadhyay et al., 1999) e do híbrido E. grandis x E. urophylla (Yang et al., 1995; Barrueto Cid et al., 1999). O desenvolvimento de sistemas de regeneração de órgãos de plantas maduras é de grande importância pois possibilita o trabalho com materiais de interesse econômico, como clones comerciais. Como em poucos casos a regeneração de tecidos de órgãos maduros, como folhas de E. citriodora (Muralidharan \& Mascareshas, 1987), caules e folhas de $E$. tereticornis (Subbbaiah \& Minocha, 1990) e folhas de clones de E. grandis (Lainé \& Davis, 1994) foi obtida com sucesso, o principal desafio é aumentar-se a eficiência e reprodutibilidade dos sistemas de regeneração, já que a transformação genética das mesmas é função direta da eficiência do processo de regeneração.

A eficiência dos sistemas de regeneração está diretamente relacionada às concentrações dos reguladores de crescimento. Takahashi et al. (1978), estudaram o efeito de 24 derivados da feniluréia em tabaco e demostraram que o tidiazuron (TDZ), apresenta propriedades de citocinina. $\mathrm{O}$ estudo do efeito de diferentes tipos de citocinina 
realizado por Tsuro et al. (1999) na formação de brotos derivados de calos, demonstrou que o TDZ possui um efeito mais eficiente que a benziladenina (BA).

No presente trabalho, o efeito do TDZ como citocinina indutora na formação de gemas foi observado em alta frequiência. Estas gemas foram capazes de desenvolver brotações que enraizaram e regeneraram plantas. O protocolo de regeneração descrito, mostrou-se bastante eficiente, tanto para diferentes tipos de explantes de E. grandis, E. urophylla e do híbrido entre ambos, como para folhas de clones comerciais de $E$. grandis. A influência do balanço hormonal e de diferentes genótipos também foi analisada.

\subsection{Material e Métodos}

\subsubsection{Material vegetal}

Sementes, provenientes de polinização aberta de E. grandis, E. urophylla e do híbrido entre ambos, providas pela Cia Suzano de Papel e Celulose SP, Brasil, foram esterilizadas por lavagens sucessivas em: etanol $70 \%$ por 1 minuto, hipoclorito de sódio $8 \%(\mathrm{p} / \mathrm{v})$ por 10 minutos em água estéril (4 lavagens). As sementes foram então semeadas em placas de Petri contendo meio MB. Este meio é composto por: metade da concentração dos macronutrientes do meio MS (Murashige \& Skoog, 1962), micronutrientes do MS, $3 \%(\mathrm{p} / \mathrm{v})$ de sacarose e $0,6 \%$ de ágar. $\mathrm{O} \mathrm{pH}$ foi ajustado para 5,8 e posteriormente autoclavado a 1 atmosfera de pressão $\left(121^{\circ} \mathrm{C}\right)$ durante 20 minutos. No meio foram adicionadas as vitaminas MS-B (Barrueto Cid et al., 1994), as quais foram esterilizadas por filtração (milipore $0,22 \mu \mathrm{m}$ de diâmetro). 
As placas foram mantidas a $26{ }^{\circ} \mathrm{C}$, sob $16 \mathrm{~h}$ de fotoperíodo e luminosidade aproximada de $50 \mu \mathrm{mol} \mathrm{m} \mathrm{m}^{-2} \mathrm{~s}^{-1}$. Estas condições de cultura estão referidas no texto, como condições de fotoperíodo. As sementes foram cultivadas por 30 dias até desenvolverem plântulas. Os cotilédones, folhas, hipocótilos e raízes das mesmas foram então utilizadas como explantes nos experimentos de regeneração.

\subsubsection{Indução de calos}

Os explantes (sem nódulos axilares) foram excisados de plântulas com 30 dias e cultivados em diferentes meios para indução de calos. Os meios utilizados para a formação de calos têm como base o MB contendo diferentes concentrações de TDZ e ANA (meios M1, M2, M3, M4, M5 e M6). Os explantes foram cultivados no escuro a $26^{\circ} \mathrm{C}$ por 30 dias.

\subsubsection{Indução de gemas}

A indução de gemas adventícias foi obtida a partir de calos derivados de diferentes tratamentos e cultivados em meios de indução de gemas. Este meio tem como base o MB acrescentado de TDZ e ANA em diferentes concentrações (M2 e M7). Os calos foram cultivados em condições de fotoperíodo, por um período de 30 dias. 
Tabela 1. Meios de cultura utilizados nos experimentos de regeneração de Eucalyptus. MM: meio de multiplicação; MA meio de alongamento; ME: meio de enraizamento. Os meios M1, M2, M3, M5, M5 e M6 foram utilizados na formação de calos e os meios M2 e M7 foram utilizados como indutores de gemas. Concentrações em $\mu \mathrm{M}$. O meio básico utilizado (MB) contém a metade da concentração dos macronutrientes do meio MS (Murashige \& Skoog, 1962), micronutrientes de MS, $3 \%$ (p/v) de sacarose e 0,6 \% de ágar. O pH 5,8 e vitaminas MS-B (Barrueto Cid et al., 1994).

\begin{tabular}{|c|c|c|c|c|}
\hline \multirow{2}{*}{$\begin{array}{l}\text { Meios de } \\
\text { cultura }\end{array}$} & \multicolumn{4}{|c|}{ Reguladores de crescimento $(\mu \mathrm{M})$} \\
\hline & BA & IBA & ANA & TDZ \\
\hline MM & 0,006 & - & 0,88 & - \\
\hline MA & 0,44 & 1 & - & - \\
\hline $\mathrm{ME}$ & - & 4,9 & - & - \\
\hline M1 & - & - & 2,5 & 1 \\
\hline M2 & - & - & 2,5 & 2 \\
\hline M3 & - & - & 5 & 1 \\
\hline M4 & - & - & 5 & 2 \\
\hline M5 & - & - & 7,5 & 1 \\
\hline M6 & - & - & 7,5 & 2 \\
\hline M7 & - & - & 1,125 & 2 \\
\hline
\end{tabular}




\subsubsection{Multiplicação e alongamento de brotos}

Para estimular o desenvolvimento e multiplicação de brotos, os calos que apresentaram formação de gemas foram mantidos inicialmente em meio $\mathrm{MB}$ acrescentado de 0,88 $\mu \mathrm{M}$ ANA e 0,006 $\mu \mathrm{M}$ BA (MM) por 30 dias. Após este período, os calos desenvolveram brotações, e foram então transferidos para meio MB contendo 1 $\mu \mathrm{M}$ IBA e 0,44 $\mu \mathrm{M}$ BA (MA) para estimular o alongamento sendo mantidos neste até atingirem aproximadamente $30 \mathrm{~mm}$ de comprimento.

\subsubsection{Avaliação da eficiência de regeneração de diferentes explantes de $E$. grandis, E. urophylla e do híbrido entre ambos}

Para avaliar a eficiência de regeneração das diferentes espécies de Eucalyptus e diferentes explantes dessas espécies, sementes de E. grandis, E. urophylla e do híbrido entre ambos foram esterilizadas e cultivadas em meio MB até o desenvolvimento das plântulas (30 dias). Os cotilédones, o primeiro par de folhas, o hipocótilo e as raízes das plântulas foram excisados. Cada explante individualizado foi então transferido para meio MB contendo $2 \mu \mathrm{M}$ de TDZ e 2,5 $\mu \mathrm{M}$ de ANA (M2), cultivados por 30 dias, na ausência de luz, sendo o meio renovado após 15 dias. Após esse período de escuro, os explantes foram mantidos no mesmo meio mas em condições de fotoperíodo por mais 30 dias antes de serem transferidos para meio de multiplicação (MM) por mais 30 dias e, finalmente, para meio de alongamento (MA).

O explante que apresentou brotações foi considerado regenerado. A taxa de regeneração foi estimada dividindo-se o número de explantes que regeneraram pelo total de explantes da parcela. $\mathrm{O}$ experimento foi inteiramente casualizado e os tratamentos 
agrupados de forma fatorial com 6 repetições. Os dados foram obtidos após 120 dias de cultivo. Considerando-se como fator 1 as espécies de eucalipto, e como fator 2, o tipo de explante. Os tratamentos resultam das combinações entre os genótipos de eucalipto e o tipo de explante. Os três genótipos utilizados foram: E. grandis, E. urophylla e o híbrido entre ambos; os quatro tipos de explantes considerados foram: raízes, cotilédones, folhas e hipocótilos, resultando assim, em doze tratamentos, sendo que cada parcela continha entre 17 e 23 explantes.

\subsubsection{Efeito dos reguladores de crescimento na eficiência de regeneração}

O efeito das diferentes concentrações de TDZ e ANA na morfogênese foi avaliado utilizando cotilédones como explantes. O delineamento estatístico foi inteiramente casualizado, com quatro repetições por tratamento, sendo que cada parcela continha 30 explantes. O experimento fatorial foi montado considerando-se como fator 1 , os meios para formação de calos (M1, M2, M3, M4, M5 e M6) e como fator 2, os meios para indução de gemas (M2 e M7), resultando assim em 12 tratamentos combinados. Os dados foram expressos em porcentagem obtida pela relação entre os calos que formaram brotações aos 120 dias pelo total de explantes da parcela.

Cotilédones e folhas de plântulas com 30 dias, provenientes de sementes de $E$. grandis, germinadas em meio $\mathrm{MB}$, foram transferidos para os diferentes tratamentos resultantes das combinações de diferentes concentrações de ANA e TDZ $(\mu \mathrm{M})$ durante a formação de calos (na ausência de luz) e também na indução de gemas (na presença de luz). Tratamentos para escuro (de desenvolvimento de calos): M1, M2, M3, M4, M5, M6 de acordo com a Tabela 1. Os calos provenientes desses diferentes tratamentos foram cultivados em 2 meios distintos M2 e M7 de indução de formação de gemas. Os calos permaneceram nestes meios por 30 dias em condições de fotoperíodo, até serem 
transferidos para o meio MM por mais 30 dias e finalmente, mantidos por 30 dias em meio MA.

O explante que apresentou brotações foi considerado como regenerado, sendo a taxa de regeneração estimada, dividindo-se o número de explantes com brotações pelo total de explantes presentes em cada parcela. A análise comparativa de médias foi feita pelo teste de Tukey $(P<0.05)$. Os dados experimentais foram analisados utilizando-se o programa SAS em GLM (SAS, 1996).

\subsubsection{Regeneração de clones comerciais de $E$. grandis}

Neste experimento foram utilizados como material vegetal três clones comercias de E. grandis $(24,321$ e 617) providos pela Cia. Suzano de Papel e Celulose, SP, Brasil. Esses clones oriundos de meristemas apicais de plantas adultas, foram mantidos in vitro em meio MM, para serem utilizados como fonte de explantes para o experimento. Folhas (sem meristemas axilares) provenientes das brotações dos clones, foram excisadas e mantidas em meio M2 (MB contendo $2 \mu \mathrm{M}$ de TDZ e 2,5 $\mu \mathrm{M}$ de ANA) para formação de calos por 30 dias na ausência de luz. Após esse período, os explantes foram mantidos no mesmo meio e transferidos para condições de fotoperíodo por 30 dias, antes de serem transferidos para meio de multiplicação (MM) por mais 30 dias e finalmente, para meio de alongamento (MA) (Tabela 1), também por um período de 30 dias.

O delineamento estatístico foi inteiramente casualizado, com três repetições por tratamento, sendo que a parcela para todos os tratamentos continha 50 explantes. Os fatores considerados foram os três clones comerciais mencionados. Os resultados estão expressos em porcentagem obtida pela relação entre calos que formaram brotações aos 120 dias, pelo total de explantes da parcela. 


\subsubsection{Enraizamento e aclimatação}

Brotos de $30 \mathrm{~mm}$ de comprimento provenientes dos explantes regenerados de $E$. grandis, E. urophylla e do híbrido entre ambos foram separados e cultivados individualmente em meio MB acrescido de 4,9 $\mu \mathrm{M}$ de IBA (ME) por 10 dias na ausência de luz, para estimular a formação de raízes antes da transferência para condições de fotoperíodo por mais 20 dias. As plântulas que enraizaram foram então transferidas para vasos de $300 \mathrm{ml}$, contendo uma mistura de substrato e vermiculita (1/1 v/v) e mantidas em casa de vegetação $\left(25^{\circ} \mathrm{C}\right.$ e $80 \%$ de umidade relativa $)$.

\subsection{Resultados e Discussão}

\subsubsection{Avaliação da eficiência de regeneração de diferentes explantes de $E$. grandis, E. urophylla e do híbrido (E. grandis $x$ E. urophylla)}

Mais de $80 \%$ das sementes germinaram depois de permanecerem uma semana em meio MB. O procedimento de desinfestação não interferiu na taxa de germinação, embora alguns trabalhos demonstrem uma interferência negativa dos sistemas de desinfestação na viabilidade das sementes (Durant-Cresswell et al., 1985). As plântulas desenvolvidas foram então utilizadas como fonte de explantes para os experimentos.

A formação de calos após o cultivo em meio M2 foi superior a $90 \%$ para os explantes de folhas, cotilédones e hipocótilos. Já, as raízes apresentaram uma taxa inferior a $50 \%$. Os calos iniciaram o desenvolvimento nas regiões de excisão dos explantes e gradualmente estenderam-se por todo o explante. Os calos apresentaram um 
crescimento rápido e vigoroso, com uma variação de cor entre o amarelo e o branco, para todos os genótipos. A boa resposta para formação de calos no escuro também foi observada por Lainé \& David (1994), e Subbaiah \& Minocha (1990), em sistemas de regeneração por organogênese em E. grandis e E. tereticornis, respectivamente. No escuro há uma inibição da oxidação dos calos, provavelmente devido à liberação de compostos fenólicos (Mayer, 1987). Dessa forma, para simplificar o protocolo ao máximo, optou-se pela não adição de antioxidantes aos meios de cultivo utilizados.

Após 30 dias os explantes foram transferidos para condições de fotoperíodo; os calos tornaram-se gradualmente escuros enquanto as gemas se formavam. Já com 60 dias de cultivo os calos apresentavam uma coloração marrom devido à oxidação dos mesmos embora tenham desenvolvido gemas (Figura 3). Estes resultados estão em concordância com o trabalho de Barrueto Cid et al. (1999), que observaram, que longas exposições à luz podem incrementar a presença de receptores específicos de indutores fenólicos (Mayer, 1987). Outro fator importante a ser considerado que pode estimular à oxidação dos calos é a presença de citocininas no meio (Durant-Cresswell et al., 1985; Horgan, 1987).

Os calos foram transferidos após 60 dias para meio MM (Tabela 1). O desenvolvimento de brotações, a partir de gemas foi observado, além do aumento gradual do número de brotos por explante, que após 30 dias em meio MM, atingiram, em média, cerca de $10 \mathrm{~mm}$ de comprimento, quando foram transferidos para meio MA e os brotos alongaram até atingirem cerca de $30 \mathrm{~mm}$ em média (Figura 4-D). O número de brotações foi muito variável sendo desenvolvidos entre 30 e 60 brotações por explante que apresentou regeneração.

As maiores eficiências de regeneração foram de 26 e $22 \%$ utilizando-se cotilédones de E. grandis e do híbrido, respectivamente. A regeneração foi superior para E. grandis e para o híbrido (E. grandis x E. urophylla), em relação à E. urophylla (Figura 2). Quanto ao efeito do tipo de explante, os resultados mostram que os 
cotilédones regeneram melhor, embora as folhas e hipocótilos também apresentam boa taxa de regeneração (Figura 2) no entanto as raízes apresentaram menor eficiência de regeneração, mostrando assim que o tipo de explante inicial tem um forte efeito na eficiência de regeneração. O mesmo foi observado nos trabalhos de Bennet \& McComb, 1982 e Laine \& David, 1994, para o caso de E. marginata e E. grandis respectivamente.

Neste protocolo o TDZ foi incorporado aos meios de formação de calos e de desenvolvimento de gemas, conseguindo-se dessa forma uma alta freqüência na indução de gemas, que apresentaram capacidade de formar brotos e regenerar plantas. Os derivados da uréia possuem efeito similar às citocininas, sendo capazes de estimular diferentes respostas morfogenéticas, inclusive a formação de brotos em diferentes espécies vegetais (Huetteman \& Precee, 1993). O efeito indutor de formação de brotações das uréias tem sido freqüentemente mais pronunciado em relação ao BAP, na maioria das espécies vegetais testadas e, particularmente, em espécies arbóreas (Lu, 1993). Embora o modo de ação destes compostos não seja totalmente conhecido (Hare \& Van Staden, 1994), parecem estar envolvidos na ativação e diferenciação de células específicas durante o processo de regeneração de hipocótilos em E. globulus (Azmi et al., 1997). Além disso, Tsuro et al., 1999 observaram que o TDZ no meio de regeneração limitou a capacidade de enraizamento dos brotos Lavandula vera, no caso de Eucalyptus a capacidade de enraizamento não foi afetada. Portanto, este sistema de regeneração apresentou-se bastante satisfatório, não só para E. grandis como também para o híbrido. 


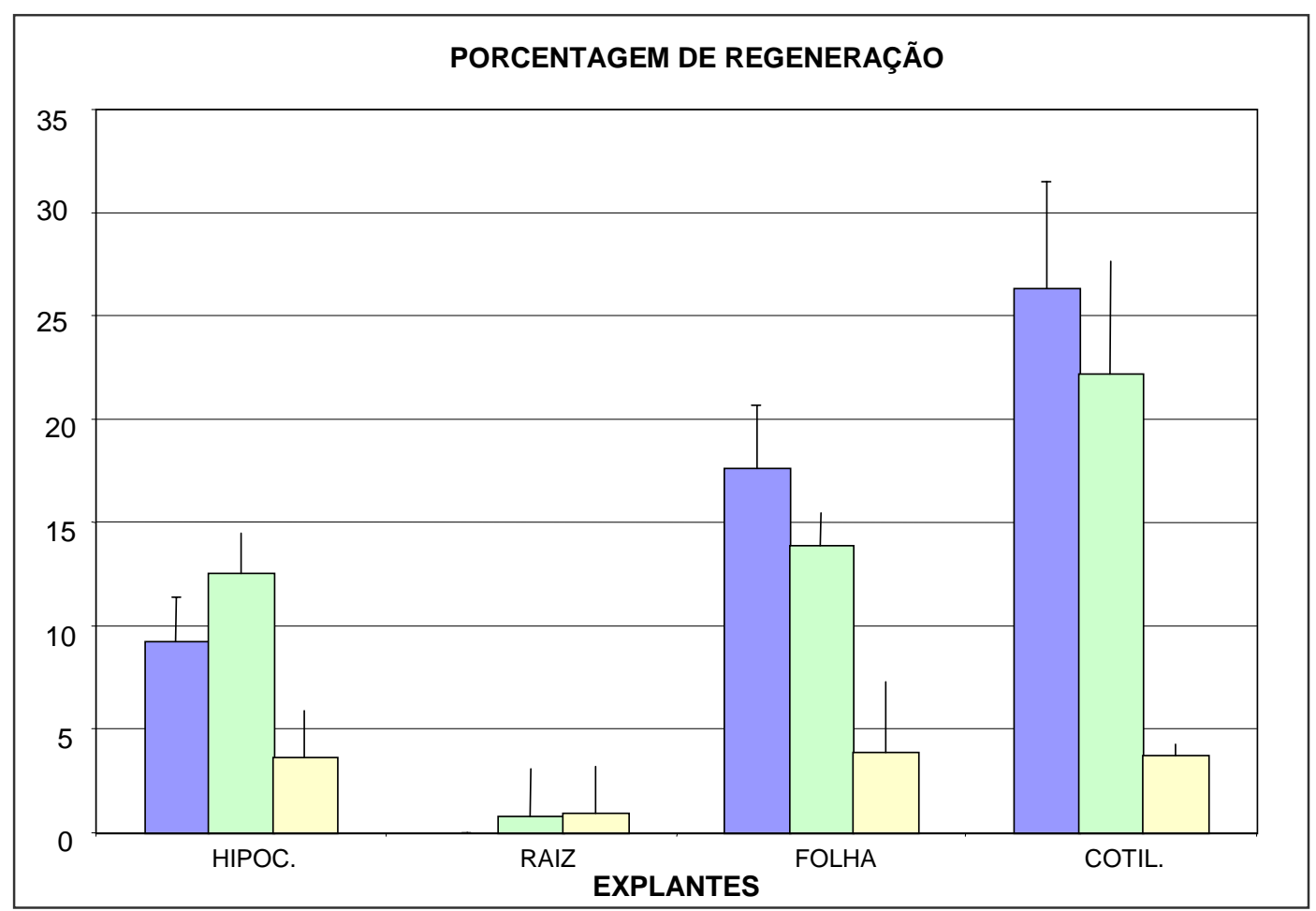

Figura 2 - Avaliação da eficiência do sistema de regeneração expressa em porcentagem, a partir de diferentes explantes e de Eucalyptus ssp.. E. grandis (azul), híbrido E. grandis $x$ E. urophylla (verde) e E. urophylla (amarelo).

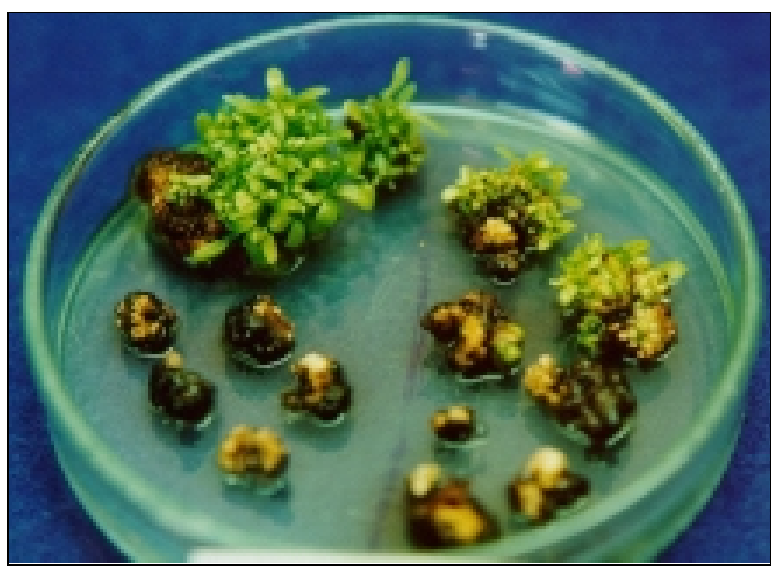

Figura 3 - Cotilédones de E. grandis com 80 dias de cultivo, formando calos que apresentam ou não o desenvolvimento de brotações. 


\subsubsection{Efeito dos reguladores de crescimento na eficiência de regeneração de cotilédones}

A composição e concentração dos reguladores de crescimento são determinantes no padrão de desenvolvimento, na maioria dos sistemas de cultura de tecidos, sendo que a disponibilidade, e também, a interação entre auxinas e citocininas presentes no meio de cultura influenciam a regeneração in vitro (Skoog \& Miller, 1957).

Os resultados da avaliação do efeito das diferentes concentrações de TDZ e ANA, durante o desenvolvimento de calos (no escuro) e na indução de gemas apresentaram taxas de regeneração entre 6,67 e 33,3 \% (Tabela 2). Pela análise estatística do experimento não houve interação entre os fatores 1 e 2, ou seja, que o meio utilizado na formação de calos não influenciou o efeito do meio de formação de gemas. Pelo teste de Tukey observou-se que as diferenças entre as médias para o fator 1 (meios de formação de calos) foram estatisticamente significativas $(\mathrm{P}<0,05)$, mas não significativas para o fator 2 (meios de diferenciação de gemas) (Tabela 2). O melhor resultado foi obtido $(32,9 \%)$ quando utilizou-se o meio M1 para a formação de calos, independentemente do meio utilizado para o desenvolvimento de gemas.

As feniluréias são conhecidas por possuírem efeitos similares aos das citocininas em diferentes espécies vegetais, entretanto as concentrações utilizadas dependem da espécie a ser considerada (Huertteman \& Preece, 1993; Lu, 1993; Barrueto Cid et al., 1997). Os resultados deste trabalho mostraram que os efeitos do TDZ foram bastante semelhantes aos observados por Le Roux \& Van Staden, (1991), Tibok et al. (1995) e Barrueto Cid et al. (1997), quanto à indução e proliferação de brotações em Eucalyptus. Os tratamentos com o meio M1 (para formação de calos) apresentaram porcentagem de regeneração superiores a 30 e foram utilizados no processo de transformação genética. 
Tabela 2. Porcentagem de regeneração de cotilédones em meios contendo diferentes concentrações de ANA e TDZ, nos estádios de formação de calos e desenvolvimento de gemas. Os dados são médias de quatro repetições. Os tratamentos seguidos de diferentes letras indicam diferenças estatisticamente significativas determinadas pelo teste de Tukey $(\mathrm{P}<0,05)$. Os números entre parênteses indicam o erro padrão da média de cada tratamento.

\begin{tabular}{|c|c|c|c|}
\hline \multicolumn{4}{|c|}{ REGENERAÇÃO DE COTILEDONES (\%) } \\
\hline \multirow{2}{*}{$\begin{array}{c}\text { Meios de } \\
\text { indução de calos }\end{array}$} & \multicolumn{2}{|c|}{ Meios de desenvolvimento de gemas } & \multirow{2}{*}{$\begin{array}{l}\text { Taxas } \\
\text { médias }\end{array}$} \\
\hline & M2 & M7 & \\
\hline M1 & $33,3(1,94)$ & $32,5(1,30)$ & 32,9 .a \\
\hline M2 & $20,0(1,22)$ & $30,0(2,11)$ & 25,0 ba \\
\hline M3 & $20,0(2,36)$ & $27,5(1,83)$ & 23,7 ba \\
\hline M4 & $27,5(1,31)$ & $18,3(0,78)$ & 22,9 ba \\
\hline M5 & $6,67(1,83)$ & $20,0(1,61)$ & $13,3 \mathrm{~b}$ \\
\hline M6 & $24,2(1,78)$ & $26,7(1,75)$ & 25,45 ba \\
\hline Taxas médias & $21,9 \mathrm{a}$ & $25,8 \mathrm{a}$ & \\
\hline
\end{tabular}

\subsubsection{Regeneração de clones comerciais de $E$. grandis}

Somente os clones 617 e 321 apresentaram regeneração de plantas (Tabela 3), sendo que desses o clone 321 apresentou a maior taxa de regeneração (48\%) com gemas que desenvolveram brotos, alongaram e enraizaram nos respectivos meios: MM, MA e ME. Enquanto o clone 24 formou calos que não apresentaram desenvolvimento de gemas. 
Com estes resultados observamos a grande influência do genótipo na regeneração in vitro.

A influência do genótipo no processo de regeneração in vitro de E. marginata também foi observada por Bennett \& Mc Comb (1982). Além disso, também foi observado diferenças na eficiência de regeneração para o caso de diferentes clones de $E$. grandis (Laine \& David, 1994).

O uso de clones apresenta algumas vantagens para a transformação genética. Uma delas é que o material transformado retém todas as características de interesse do clone original, o que não acontece para o caso de trabalhos com sementes. Outra característica particularmente importante em trabalhos com Eucalyptus está relacionada a uma resposta mais uniforme dos clones quanto aos sistemas de seleção de transformantes, principalmente com relação à resistência a determinados antibióticos. No caso de sementes González et al., (2001) observaram uma variabilidade muito grande quanto à susceptibilidade à canamicina e geneticina G418.

Com base nestas observações, seria interessante utilizar a característica vantajosa do clone 321, uma vez que apresenta taxa de regeneração elevada (48\%), em experimentos de transformação genética.

Tabela 3. Porcentagem de regeneração de folhas dos clones comerciais 617, 321 e 24 . Os dados são médias de duas repetições contendo 50 explantes cada.

\begin{tabular}{lcc}
\hline Genótipos & Regeneração $(\%)$ & Erro padrão \\
\hline Clone 617 & 16,0 & 1,50 \\
Clone 321 & 48,0 & 1,44 \\
Clone 24 & 0,00 & 0 \\
\hline
\end{tabular}




\subsubsection{Enraizamento e aclimatação}

Brotos com 3-4 cm de cumprimento de E. grandis, E. urophylla, do híbrido entre ambos e dos clones 617 e 321 foram transferidos para meio ME. Todos os genótipos apresentaram taxa de enraizamento de 80 a $90 \%$. Os primórdios radiculares foram desenvolvidos após 10 dias no escuro, e após outros 10 dias em condições de fotoperíodo, as raízes alongaram (Figura 4-F, G). Um dos fatores que facilitou o enraizamento de brotos foi a redução da concentração salina nos meios, tal como foi citado por Chalupa (1987), e Chang \& Yang (1995) esta condição permite o aumento da freqüência de enraizamento. Neste último trabalho utilizou-se E. camaldulensis e o meio de enraizamento foi acrescido de 4,9 $\mu \mathrm{M}$ de IBA, exatamente a mesma concentração utilizada para o preparo do meio de enraizamento neste trabalho.

As plântulas enraizadas foram transferidas para casa de vegetação e a aclimatação foi satisfatória, com uma taxa superior a $90 \%$ (Figura 4F) não havendo grandes diferenças com relação aos genotípos. 


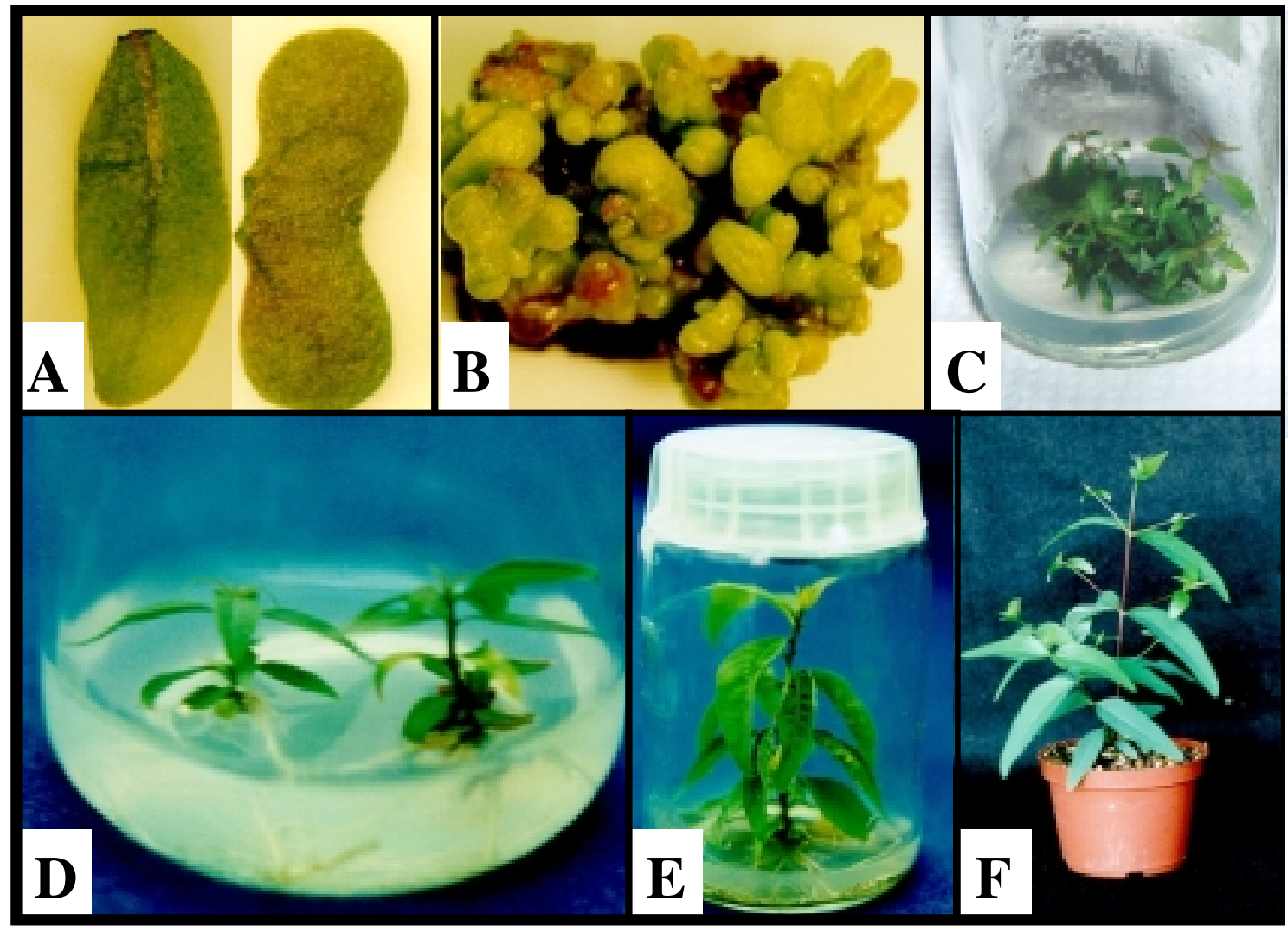

Figura 4 - Regeneração de explantes oriundos de plântulas e folhas de clones de eucalipto. (A) Cotilédones de plântulas (esquerda) e folhas extraídas de clones micropropagados (direita). (B) Calo organogenético com desenvolvimento de gemas. (C) Calo com brotações alongando. (D) Brotações em enraizamento. (E) Plântula enraizada. (F) Plantas regeneradas e aclimatadas em casa de vegetação.

\subsection{Conclusões}

Desenvolveu-se, através da organogênese indireta, um sistema de regeneração eficiente e reprodutível a partir de explantes oriundos de plântulas e folhas de clones micropropagados. O método compreende 5 etapas essenciais: Indução de calos no escuro, formação de gemas em condições de fotoperíodo, desenvolvimento e alongamento de brotos e finalmente, enraizamento em meio de cultivo acrescido de IBA. 
Este protocolo é um importante passo para a obtenção de plantas transgênicas e foi utilizado nos experimentos de transformação genética. 


\section{OBTENÇÃO DE PLANTAS TRANSGÊNICAS DE Eucalyptus grandis E $E$. grandis $x$ E. urophylla MEDIANTE INOCULAÇÃO COM Agrobacterium}

\section{Resumo}

Neste trabalho desenvolveu-se um método de transformação de sementes em fase inicial de germinação de E. grandis e do híbrido (E. urophylla X E. grandis) utilizandose o método de inoculação com Agrobacterium tumefaciens assistida pela técnica de sonicação. As maiores porcentagens de expressão transitória da $\beta$-glucuronidase $(21,7 \%$ e $37,5 \%$ ) foram obtidas para a inoculação de sementes pré-cultivadas durante 2 e 15 dias respectivamente, quando sonicadas por 30 s. A sonicação anterior à inoculação provocou um aumento na eficiência de transformação. A avaliação dos tecidos transformados com a utilização de sementes em pré-cultivo por 2 dias, apresentou mais de $90 \%$ dos pontos de transformação localizados nos cotilédones e na parte basal do hipocótilo. Já para sementes em pré-cultivo por 15 e 17 dias observou-se que cerca de $60 \%$ das áreas de transformação concentraram-se no primeiro par de folhas. O tempo durante o qual foram sonicados os explantes influenciou na eficiência de transformação, sendo que a maior taxa de transformação $(37,2 \%)$ foi obtida quando as sementes foram sonicadas por 120 segundos antes de serem inoculadas. A eficiência do sistema foi avaliada pelos experimentos de obtenção de plantas transgênicas de E. grandis com o gene marcador uidA, mas também foram obtidas plantas transgênicas do híbrido (E. grandis $x E$. urophylla) com o gene quimérico Lhcbl $* 2$ (chlorophyll a/b binding protein) de ervilha, pertencente ao sistema antena LHCII. Os eventos de transformação foram então confirmados pela técnica de Southern blot. 


\section{PRODUCTION OF TRANSGENIC Eucalyptus grandis AND E. grandis $x$ E. urophylla Agrobacterium-MEDIATED INOCULATION}

\section{Summary}

A method for genetic transformation of germinating seeds of Eucalyptus grandis and E. grandis x E. urophylla is described using the sonication assisted Agrobacteriummediated transformation (SAAT) system. Seeds germinated for 2 days and 15-day-old seedlings, sonicated for $30 \mathrm{~s}$, had the highest percentage of $\beta$-glucuronidase (GUS) transient expression $(21.7 \%$ and $37.5 \%$ respectively). Pre-sonication greatly enhanced the efficiency of transformation. The differential transformation of tissues was also investigated, with seeds imbibed for 2 days having over $90 \%$ of the blue sectors localized in cotyledons and in the intersection of the hypocotyls and roots. On the other hand, 15-17 days old seedlings had around $60 \%$ of transformed sectors localized in the first pair of leaves. The evaluation of the different sonication times showed $120 \mathrm{~s}$ as the best one $(37,2 \%)$. The efficiency of the method was assessed not only by obtaining transgenic plants of E. grandis with the marker gene uidA, but also by transformation of the hybrid Eucalyptus grandis $\mathrm{x}$ Eucalyptus urophylla with a chimeric construct containing the $L h c b l * 2$ gene of the $28 \mathrm{kDa}$ chlorophyll $a / b$ binding pea protein from the LHCII antenna. Stable transformants were confirmed by genomic blotting. 


\subsection{Introdução}

A transformação genética de Eucalyptus tem sido o objetivo de vários grupos de pesquisa nos últimos anos, tanto no setor público como no privado. Poucos trabalhos, relatam a obtenção de plantas transgênicas das principais espécies de interesse econômico. Serrano et al. (1996), utilizaram biobalística com o objetivo de introduzir DNA em embriões zigóticos de E. globulus, conseguindo assim calos com expressão do gene marcador uidA da $\beta$-Glucuronidase. A integração do DNA foi demonstrada por Southern blot, embora não tenham conseguido regenerar plantas transformadas. Já, Moralejo et al. (1998), obtiveram plantas transgênicas de E. globulus utilizando embriões zigóticos injuriados por bombardeamento, seguido da inoculação com $A$. tumefaciens e Mullins et al. (1997), também obtiveram plantas transgênicas de $E$. camaldulensis via inoculação com A. tumefaciens de folhas de um único clone, de 24 testados. Ho et al. (1998), obtiveram plantas transgênicas de E. camaldulensis utilizando a inoculação com A. tumefaciens de hipocótilos provenientes de plântulas. Entretanto não há relatos de obtenção de plantas transgênicas de E. grandis e do híbrido E. grandis $x$ E. urophylla, que representam grande parte das plantações de eucalipto comercialmente importantes em regiões tropicais e subtropicais.

Diferentes estratégias têm sido desenvolvidas com o objetivo de aumentar a eficiência de transformação via Agrobacterium, tais como: uso de bombardeamento com microprojéteis, com o intuito de causar microferimentos nos tecidos (Bidney et al., 1992; Moralejo et al., 1998); uso de vetores binários que expressam alguns genes de virulência (vir) de forma constitutiva (Ishida et al., 1996). Recentemente uma nova técnica foi desenvolvida, que utiliza o ultra-som no pré-tratamento ou durante a inoculação com $A$. tumefaciens. Esta técnica permitiu aumentar a eficiência de transformação genética de soja, trigo e milho (Trick \& Finner, 1997; 1998; Santarém et al., 1998). A aplicação de

ultra-som em tecidos de plantas induz cavitações acústicas, que geram poros 
microscópicos, permitindo assim a exposição de tecidos internos à A. tumefaciens (Trick \& Finner, 1997) o que leva a um aumento dos níveis de expressão transitória do T-DNA.

Nos experimentos de transformação genética de Eucalyptus os explantes mais frequientemente utilizados são: cotilédones, hipocótilos, embriões zigóticos e folhas, não havendo relatos sobre a inoculação com A. tumefaciens de sementes em germinação. Os trabalhos de Feldmann \& Marks (1987), com Arabidopsis e Chee et al. (1989) com soja, mostram sistemas de transformação de sementes em germinação, embora a eficiência para ambas espécies tenha sido baixa. A utilização de sementes em germinação oferece a possibilidade de inocular-se grandes quantidades de material vegetal além de evitar-se a passagem pela cultura de tecidos, diminuindo assim as possibilidades de variação somaclonal (Feldmann \& Marks, 1987).

Neste trabalho, foi desenvolvida uma metodologia de transformação de sementes em germinação de E. grandis e do híbrido E. grandis $x$ E. urophylla via inoculação com A. tumefaciens do material previamente sonicado. A eficiência da técnica de sonicação, foi inicialmente avaliada pelo teste histológico da ß-glucuronidase (GUS) em sementes inoculadas considerando-se vários parâmetros dentro de cada tratamento. Depois foram estabelecidas as condições de inoculação, co-cultivo e seleção dos explantes. Já com o protocolo estabelecido, foi utilizada a construção quimérica contendo o gene de ervilha $L h c b 1 * 2$ que codifica a proteína de $28 \mathrm{kDa}$ do sistema antena LHCII, para a obtenção de plantas transgênicas. Quatro plantas transgênicas, originadas de quatro eventos independentes, foram obtidas e analisadas através da técnica de Southern blot. 


\subsection{Material e Métodos}

\subsubsection{Material vegetal}

Sementes de polinização aberta de E. grandis, E. urophylla e do híbrido entre ambas foram fornecidas pela Cia Suzano de Papel e Celulose SP, Brasil. Estas foram esterilizadas por lavagens sucessivas em: etanol 70 \% (1 minuto), hipoclorito de sódio 8 $\%(\mathrm{p} / \mathrm{v})$ (10 minutos) e água estéril (4 lavagens, de 5 minutos), antes de serem semeadas em placas de Petri contendo meio MB. O meio MB é composto pela metade da concentração dos macronutrientes do meio MS de Murashige \& Skoog, (1962), micronutrientes de MS, $3 \%(\mathrm{p} / \mathrm{v})$ de sacarose e 0,6 \% de ágar. $\mathrm{O} \mathrm{pH}$ foi ajustado para 5,8 antes da esterilização por autoclavagem a $121^{\circ} \mathrm{C}$, durante 20 minutos. As vitaminas MS-B (Barrueto Cid et al., 1994) foram esterilizadas com filtro (milipore 0,22 $\mu \mathrm{m}$ ) e adicionadas ao meio MB já estéril. As sementes foram mantidas, a $26{ }^{\circ} \mathrm{C}$, com $16 \mathrm{~h}$ de fotoperíodo, e luminosidade aproximada de $50 \mu \mathrm{mol} \mathrm{m}^{-2} \mathrm{~s}^{-1}$ para que germinassem. Estas condições de cultura foram referidas no texto como condições de fotoperíodo.

\subsubsection{Linhagens, plasmídeos e condições de cultura da A. tumefaciens}

A linhagem de A. tumefaciens utilizada nas construções do plasmídeo binário pEND4K (Klee et al., 1985) foi a LBA4404. A primeira construção utilizada contém na região do T-DNA dois genes: o marcador uidA que codifica a enzima B-glucuronidase (Jefferson et al., 1987) e o gene da neomicina fosfotransferase (nptII) que confere resistência à canamicina e geneticina G418 (Figura 5). O gene uidA contém um intron 
que inibe a expressão do mesmo em Agrobacterium sendo sua expressão regulada pelo promotor 35S do vírus do mosaico da couve-flor (CaMV35S). Já o gene nptII está sob o controle do promotor da nopalina sintase (pnos) (Figura 5A). A segunda construção contém o gene nptII sob o controle do pnos e o gene Lhcbl*2 de ervilha. Esse gene esta sob o controle do promotor CaMV35S e codifica a proteína de $28 \mathrm{kDa}$ do sistema antena LHCII pertencente ao fotosistema II (Cashmore, 1984). Com o objetivo de promover o direcionamento da proteína aos cloroplastos foi clonada junto ao gene $L h c b 1 * 2$ a região 5' não traduzida e o peptídeo trânsito da Ribulose-1,5-bifosfato carboxilase (Figura 5B).

As células bacterianas foram cultivadas por $48 \mathrm{~h}$ sob agitação constante a $28{ }^{\circ} \mathrm{C}$ em meio AB (Ishida et al., 1996), contendo $50 \mathrm{mg} . \mathrm{L}^{-1}$ de canamicina, até atingirem a fase logarítmica de crescimento $\left(\mathrm{DO}_{600}=0,7-1,0\right)$. Foram então sedimentadas por centrifugação a $4700 \mathrm{~g}$ por 10 minutos e ressuspendidas em meio MS (Murashige \& Skoog, 1962), acrescido de $100 \mathrm{mM}$ de acetoseringona (Stachel et al., 1985).

\subsubsection{Inoculação e co-cultura}

Sementes em diferentes estádios de germinação (tempos de pré-cultivo), foram colocadas em frascos de vidro estéreis $(150 \mathrm{ml}$ ) contendo $35 \mathrm{ml}$ de meio MS líquido (ou outro meio indicado no texto) e sonicadas utilizando-se um sonicador de banho (modelo ULTRA-SOM T14, 40 kHz, Eletrônicos Thornton INPEC, Piracicaba-SP), antes de serem inoculadas com Agrobacterium e mantidas a $28{ }^{\circ} \mathrm{C}$ por $24 \mathrm{~h}$ sob agitação constante $(100 \mathrm{rpm})$. Após a inoculação, as sementes foram transferidas para meio MB sólido para co-cultivo por $48 \mathrm{~h}$. e posteriormente foram lavadas com água estéril contendo $200 \mathrm{mg} \mathrm{L}^{-1}$ de cefotaxima. Após secagem em papel de filtro estéril, foram então transferidas para meio MS sólido contendo $100 \mathrm{mg} \mathrm{L}^{-1}$ de cefotaxima. Os explantes controle (não inoculados) também foram transferidos, após a sonicação para o 
mesmo meio de co-cultivo. A avaliação dos explantes foi feita após 10 dias de cultivo, pela determinação da atividade da ß-glucuronidase (GUS).

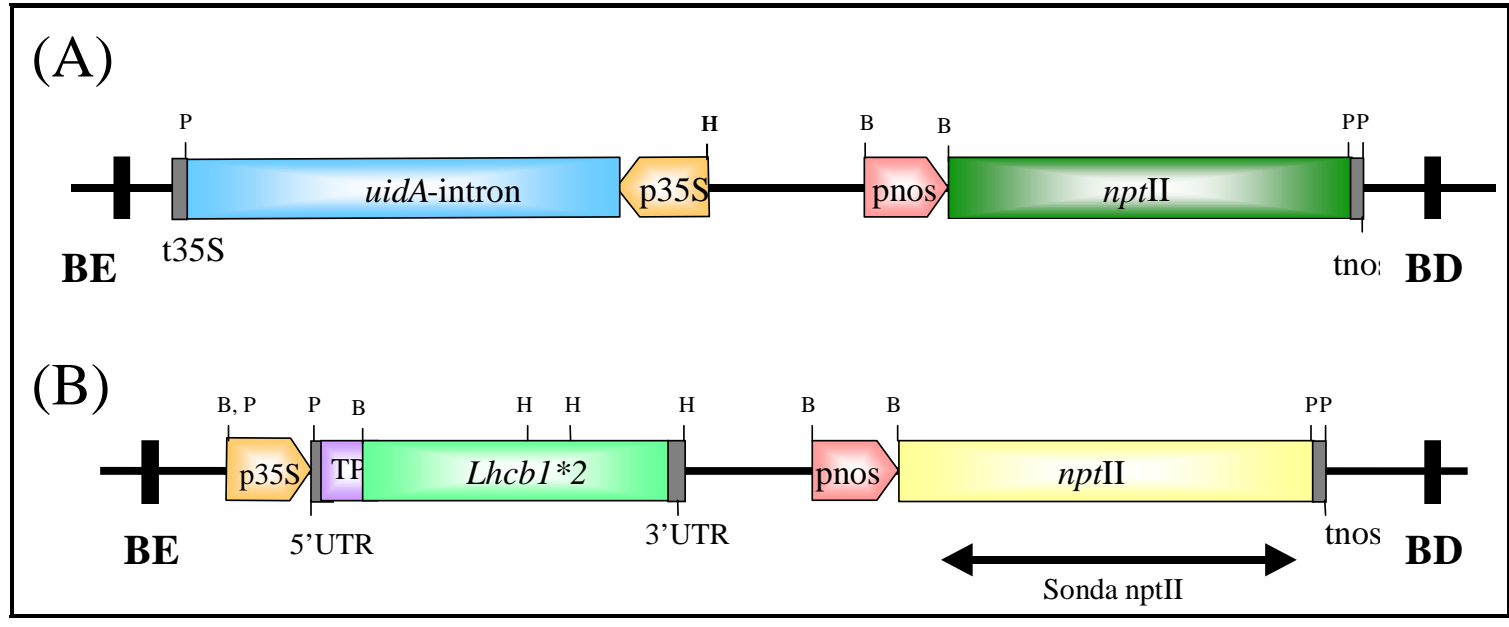

Figura 5 - Mapa das construções do T-DNA pertencente ao plasmídeo binário pEND4K usado para os experimentos. (A) Construção CaMV35S-uidA-INTRON e (B) Construção CaMV35STP-LHCB1*2. uidA, nptII:, gene da $\beta$-glucuronidase (GUS) e neomicina fosfotransferase, respectivamente. Gene Lhcbl*2, TP and 5'UTR: peptídeo de trânsito da sub-unidade menor do gene da ribulose-1,5bisfosfato carboxilase (Rbcs) e a região 5' não traduzida. 3'UTR derivado do gene de ervilha Lhcbl*2. B: BamHI, H:Hind III, P: Pst1. p35S e t35S: promotor e terminador do gene $35 \mathrm{~S}$ do vírus do mosaico da couve flor. pnos e tnos: Promotor e terminador do gene da nopalina sintase. BE e BD: bordas esquerda e direita do T-DNA.

\subsubsection{Ensaio histoquímico da B-glucuronidase}

A expressão da ß-glucuronidase (GUS) foi avaliada pelo teste histoquímico; as plântulas foram imersas na solução (Jefferson, 1987) contendo: 10mM Na $2 \mathrm{EDTA}_{2} \mathrm{H}_{2} \mathrm{O}$, 0,1\% Triton $\mathrm{X}-100,0,1 \mathrm{M} \mathrm{NaH}{ }_{2} \mathrm{PO}_{4}, 0,5 \mathrm{M} \mathrm{K}_{3} \mathrm{Fe}(\mathrm{CN})_{6}$, e $250 \mu \mathrm{g} \cdot \mathrm{mL}^{-1}$ 5-bromo-4chloro-3-indolyl $\beta$-D-glucuronic acid (X-GLUC, Inalco-USA) e mantidas por $12 \mathrm{~h}$ à 
$37^{\circ} \mathrm{C}$. Após este período, os tecidos foram lavados e a clorofila, eliminada pela lavagem com etanol 70\%. A avaliação da expressão GUS foi feita contando-se o número de regiões de coloração azul por explante.

\subsubsection{Análise dos dados}

Um explante foi considerado transformado quando apresentou pelo menos uma região de coloração azul ( expressão da GUS). A taxa de transformação foi calculada com base no número de explantes transformados dividido pelo total de explantes de cada parcela e o grau de infecção está representado pelo número médio de setores com expressão GUS por explante, calculado para cada parcela. As tabelas 5, 6 e 7 apresentam as médias de cada tratamento. Os dados foram analisados utilizando-se o aplicativo GLM do pacote SAS (SAS, 1996).

\subsubsection{Efeito dos estádios de desenvolvimento das sementes e da sonicação na eficiência de transformação}

Sementes em diferentes estádios de desenvolvimento $(0,2,5,15$ e 17 dias de précultivo) foram sonicadas durante $30 \mathrm{~s}$ antes de serem inoculadas e mantidas sob cocultivo com Agrobacterium. No tratamento controle, as sementes foram inoculadas e cocultivadas sem serem submetidas ao tratamento de sonicação. Após 10 dias de cultivo, os explantes foram avaliados quanto à atividade da ß-glucuronidase

O experimento foi organizado em blocos ao acaso e os tratamentos de forma fatorial, com duas repetições por tratamento e 20 explantes por parcela. $\mathrm{O}$ fator 1 refere- 
se aos estádios de desenvolvimento das sementes $(0,2,5,15$ e 17 dias) e o fator 2 ao efeito da sonicação (controle vs. sonicação por $30 \mathrm{~s}$ ). A análise comparativa de médias foi feita utilizando-se o teste de Student com o nível de significância de 0,05.

\subsubsection{Efeito do tempo de sonicação na eficiência de transformação}

Neste experimento, avaliou-se o efeito de tempos variáveis de sonicação antes e durante a inoculação das sementes, que foram utilizadas como explantes. As sementes permaneceram 2 dias em meio MS e foram sonicadas durante tempos variáveis antes e durante a inoculação com Agrobacterium. Após a inoculação as sementes foram mantidas a $28{ }^{\circ} \mathrm{C}$ por $24 \mathrm{~h}$ em agitação constante $(100 \mathrm{rpm})$ em meio MS líquido e posteriormente transferidas para meio MS sólido para o co-cultivo por $48 \mathrm{~h}$. Depois, as sementes foram lavadas com água estéril contendo $200 \mathrm{mg} \mathrm{L}^{-1}$ de cefotaxima, levemente secas em papel de filtro estéril e transferidas para meio MS acrescido de $100 \mathrm{mg} \mathrm{L}^{-1}$ de cefotaxima. Após 10 dias de cultivo os explantes foram avaliados quanto à atividade da GUS.

O experimento foi inteiramente casualizado com 5 repetições e cada parcela continha 30 sementes. Os tratamentos foram organizados de forma fatorial. O fator 1 , refere-se aos tempos de sonicação anteriores da inoculação, considerando os intervalos de tempo de 0,30,60, 90 e 120 segundos. O fator 2 refere-se à sonicação durante a inoculação, considerando os intervalos de tempo de 0,15 e 30 segundos. A eficiência de transformação foi expressa como a porcentagem de explantes que apresentaram pelo menos uma região com expressão GUS. 


\subsubsection{Influência dos diferentes meios e condições de luminosidade durante o co- cultivo na eficiência de transformação}

Neste experimento foi testado o efeito dos diferentes meios e condições de luminosidade durante o co-cultivo na eficiência de transformação. Sementes cultivadas por 2 dias em meio MS e sonicadas por 120 segundos foram inoculadas e co-cultivadas em diferentes meios de cultura (Tabela 4). O experimento foi organizado em blocos ao acaso, e os tratamentos distribuídos de forma fatorial. Como fator 1 considerou-se os meios de co-cultivo: MA, MM, ME, MS, M2, M8, M9 e M10 (Tabela 4) e como fator 2 as condições de luminosidade com fotoperíodo e ausência de luz. O experimento foi montado com 5 repetições por tratamento sendo que cada parcela continha 30 explantes. A análise comparativa de médias foi feita pelo teste de Tukey $(\mathrm{P}<0,05)$. 
Tabela 4. Meios utilizados nos experimentos de regeneração de Eucalyptus. MM: meio de multiplicação; MA meio de alongamento; ME: meio de enraizamento. $\mathrm{O}$ meio básico utilizado (MB) contém a metade da concentração dos macronutrientes do meio MS (Murashige \& Skoog, 1962), micronutrientes de MS, $3 \%(\mathrm{p} / \mathrm{v})$ de sacarose e 0,6 \% de ágar. O pH 5,8 e vitaminas MS-B de Barrueto Cid et al., (1994).

\begin{tabular}{|c|c|c|c|c|c|c|}
\hline Meios & $\begin{array}{l}\mathrm{BA} \\
(\mu \mathrm{M})\end{array}$ & $\begin{array}{l}\text { IBA } \\
(\mu \mathrm{M})\end{array}$ & $\begin{array}{l}\text { ANA } \\
(\mu \mathrm{M})\end{array}$ & $\begin{array}{l}\text { TDZ } \\
(\mu \mathrm{M})\end{array}$ & $\begin{array}{r}2,4-\mathrm{D} \\
(\mu \mathrm{M})\end{array}$ & $\begin{array}{l}\text { Água de } \\
\text { coco }(\mathrm{ml})\end{array}$ \\
\hline MM & 0,006 & - & 0,88 & - & - & - \\
\hline MA & 0,44 & 1 & - & - & - & - \\
\hline $\mathrm{ME}$ & - & 4,9 & - & - & - & - \\
\hline M1 & - & - & 2,5 & 1 & - & - \\
\hline M2 & - & - & 2,5 & 2 & - & - \\
\hline M7 & - & - & 1,125 & 2 & - & - \\
\hline M8 & 0,44 & - & 5,5 & - & - & - \\
\hline M9 & - & - & - & - & - & 100 \\
\hline M10 & 0,44 & - & - & - & 2,25 & - \\
\hline
\end{tabular}




\subsubsection{Tolerância de $E$. grandis a diferentes agentes seletivos}

O nível de tolerância de cotilédones de E. grandis aos antibióticos geneticina e canamicina foi avaliado. Sementes desinfestadas e cultivadas por dois dias em meio MS foram sonicadas por $120 \mathrm{~s}$, inoculadas e co-cultivadas com A. tumefaciens (GUS-NPTII). Após o co-cultivo, as sementes foram mantidas por 20 dias em meio MS contendo 200

mg L $\mathrm{L}^{-1}$ de cefotaxima até o desenvolvimento de plântulas. Uma amostra de 50 plântulas foi avaliada verificando-se a atividade da GUS.

$\mathrm{O}$ experimento foi inteiramente casualizado, com 4 repetições por tratamento sendo que cada parcela compreende 50 explantes. Os tratamentos então considerados como: controle (sem agente seletivo), canamicina nas concentrações de 50 e $100 \mathrm{mg} . \mathrm{L}^{-1}$ e geneticina G418 nas concentrações de 2,5; 5 e $10 \mathrm{mg} . \mathrm{L}^{-1}$. O controle positivo da taxa de regeneração foi feito com cotilédones na ausência do agente seletivo.

Os cotilédones provenientes das pântulas foram cortados e transferidos para meio M1 (contendo as diferentes concentrações de agentes seletivos), cultivados por 30 dias, na ausência de luz, sendo renovado após 15 dias. Após esse período, os calos formados foram transferidos para condições de fotoperíodo em meio M2 para a formação de gemas (contendo diferentes agentes seletivos), por mais 30 dias. Os calos apresentando gemas foram então, transferidos para meio de multiplicação (MM) acrescido das mesmas concentrações de agentes seletivos.

Os parâmetros avaliados com relação à tolerância aos agentes seletivos foram: mortalidade dos explantes após 30 dias, capacidade de formação de calos após 45 dias, regeneração de brotos após 60 dias e expressão da GUS nos calos, após 70 dias. 


\subsubsection{Avaliação da susceptibilidade de $E$. grandis, $E$. urophylla e do híbrido entre ambos à linhagem LBA4404 de A. tumefaciens}

A susceptibilidade de E. grandis, E. urophylla e do híbrido entre ambas à linhagem LBA4404 (GUS-NPTII) de A. tumefaciens foi avaliado. As sementes cultivadas por 2 dias em meio MS e sonicadas por $120 \mathrm{~s}$ foram inoculadas e transferidas para meio MS sólido para o co-cultivo durante $48 \mathrm{~h}$. Depois do co-cultivo as sementes foram lavadas com água estéril contendo $200 \mathrm{mg} \mathrm{L}^{-1}$ de cefotaxima, levemente secas em papel de filtro estéril e transferidas ao meio MS com $100 \mathrm{mg} \mathrm{L}^{-1}$ de cefotaxima. Os explantes controle (sem inóculo) foram transferidos, imediatamente para o meio MS. Após 10 dias da etapa anterior os explantes foram revelados, avaliando-se a atividade da GUS.

O experimento foi inteiramente casualizado com 6 repetições e o tamanho da parcela foi de 30 sementes. A eficiência de transformação foi avaliada através da porcentagem de explantes que apresentaram ao menos uma região de expressão GUS.

\subsubsection{Seleção, regeneração e obtenção de plantas transgênicas}

Dois experimentos foram realizados com o objetivo de obter plantas transgênicas a partir da inoculação de sementes. O primeiro com o híbrido E. grandis $x$ E. urophylla e a construção CaMV35SPTLHCB1*2 e o segundo, utilizando-se E. grandis e a construção CaMV35SGUS-INTRON. Para cada experimento utilizaram-se 2000 cotilédones, sendo que $50 \%$ passaram pela seleção com $50 \mathrm{mg} . \mathrm{L}^{-1}$ de canamicina e o 50 $\%$ restante foram selecionados com $5 \mathrm{mg} . \mathrm{L}^{-1}$ de geneticina G418. 
As sementes cultivadas por 2 dias em meio MS e sonicadas por $120 \mathrm{~s}$ foram inoculadas e transferidas para meio MS sólido para o co-cultivo durante $48 \mathrm{~h}$. Depois do co-cultivo as sementes foram lavadas com água estéril contendo $200 \mathrm{mg} \mathrm{L}^{-1} \mathrm{de}$ cefotaxima, levemente secas em papel de filtro estéril e transferidas ao meio MS com $100 \mathrm{mg} \mathrm{L}^{-1}$ de cefotaxima. A regeneração de plantas transgênicas foi obtida pelo cultivo in vitro a partir de cotilédones obtidos de plântulas com 15 dias após o co-cultivo. Os cotilédones excisados foram transferidos para meio M1 (contendo o agente seletivo) e mantidos por 30 dias, na ausência de luz para indução da formação de calos. Após esse período, os calos foram transferidos para o meio M2 (contendo o agente seletivo) por mais 30 dias em condições de fotoperíodo, para a formação de gemas. Os calos contendo gemas foram então transferidos para meio de multiplicação (MM) acrescido do agente seletivo. Após 30 dias, os calos foram então transferidos para meio de alongamento (MA) contendo o agente seletivo, onde permaneceram por mais 30 dias.

No caso dos explantes em regeneração, os brotos foram separados e cultivados individualmente, por 20 dias em meio MA contendo o agente seletivo. Para o enraizamento, brotos com cerca de $40 \mathrm{~mm}$ de comprimento foram transferidos para meio MB contendo 4,9 $\mu \mathrm{M}$ de IBA (ME) e mantidos por 10 dias na ausência de luz, antes de serem transferidos para condições de fotoperíodo por 20 dias. As plântulas que enraizaram foram aclimatadas e transferidas para vasos contendo uma mistura $(1: 1 \mathrm{v} / \mathrm{v})$ de substrato e vermiculita e mantidas em casa de vegetação por um mês, quando foram amostradas para a análise de Southern blot.

\subsubsection{Extração de DNA e hibridização por Southern blot}

A extração de DNA total foi feita utilizando-se folhas jovens através do kit de purificação de DNA genômico Wizard ${ }^{\mathrm{TM}}$ da Promega de acordo com as normas do 
fabricante. A digestão do DNA total $(10 \mu \mathrm{g})$ foi feita com um excesso (50 unidades) da enzima HindIII a $37^{\circ} \mathrm{C}$ por $16 \mathrm{~h}$. Os fragmentos de restrição foram separados em gel de agarose $(1 \%)$, transferidos para membrana de nylon $\left(\mathrm{Hybond}^{+}\right.$, Amersham Pharmacia Biotech) e posteriormente, hibridizados com uma sonda do gene nptII marcada com fluoresceina com o auxilio do kit (“Gene Image Random Prime Labelling Module”) da Amersham Pharmacia Biotech (CA, USA). A sonda de DNA marcada foi revelada com "CDP-Star detection system” da Amersham Pharmacia Biotech (CA, USA), através da sensibilização da chapa de Raio X, de acordo com as normas do fabricante.

\subsection{Resultados e Discussão}

\subsubsection{Efeito dos estádios de desenvolvimento das sementes e da sonicação na eficiência de transformação}

Tanto o estádio de desenvolvimento da semente como a sonicação são fatores muito importantes quando se avalia a eficiência de transformação. A análise estatística não apresentou interação entre os fatores analisados, embora mostre diferenças estatisticamente significativas entre as médias dos níveis dos fatores analisados separadamente. Os resultados (Tabela 5) indicam que o sistema de inoculação de sementes do híbrido E. grandis $x$ E. urophylla, quanto à eficiência de transformação, assemelha-se à Arabidopsis (Feldmann \& Marks, 1987). A porcentagem de explantes não sonicados (controle) com expressão da GUS variou de 2,17 \% a 17,1 \% para o caso de sementes pré-cultivadas durante 2 e 15 dias, respectivamente. $\mathrm{O}$ efeito da sonicação foi benéfico, pois aumentou os níveis de expressão GUS, não só quanto à porcentagem mas também, com relação ao grau de expressão da mesma (Tabela 5). A diferença da porcentagem média de transformação em explantes que não foram sonicados $(9,16 \%)$ e 
sonicados $(17,64 \%)$ foi estatisticamente significativa (Tabela 5). Estes resultados assemelham-se aos obtidos por Trick \& Finner, 1997; Santarém et al., 1998 e Trick \& Finer, 1998 que mostram que a sonicação aumenta a eficiência da transformação via $A$. tumefaciens, em diferentes espécies vegetais. A sonicação incrementa a transferencia do T-DNA não só porque gera microferimentos na superfície dos tecidos facilitando a penetração bacteriana, mas também porque induz a liberação de compostos fenólicos (Stachel et al., 1985; Joersbo \& Brunstedt, 1992).

O estádio de desenvolvimento da semente é um fator muito importante quando se avalia a eficiência de transformação. No caso de sementes que não foram pré-cultivadas (0 dia) a porcentagem de transformação foi baixa $(2,17 \%)$, sendo que a sonicação foi benéfica também nesse caso. Como observa-se na tabela 5 a taxa de transformação duplicou para esse caso, passando de 2,17 para 4,02\%. Sementes pré-cultivadas por 2, 5, 15 e 17 dias mostraram um notável aumento na taxa de transformação, possivelmente devido ao aumento na taxa de divisão celular durante a germinação, o que permitiria uma maior susceptibilidade à Agrobacterium como mencionado por Villemont et al., (1997). Outro fator que pode estar influenciando a susceptibilidade à Agrobacterium pode ser o aumento no nível de transcrição (Moralejo et al., 1998). Os melhores resultados foram obtidos utilizando a sonicação em sementes pré-cultivadas durante 2 , 15 e 17 dias (Tabela 5 e Figura 6 A-C), embora as sementes com 5 dias de pré-cultivo tenham apresentado baixas taxas de transformação, provavelmente devido ao estado de germinação, sendo que neste período os cotilédones encontram-se desenvolvidos e com baixa taxa de divisão celular.

$\mathrm{Na}$ análise dos órgãos em que se encontram as áreas de transformação, observamos que sementes pré-cultivadas por 2 dias apresentam mais de $90 \%$ das áreas com expressão da GUS localizadas nos cotilédones e na intersecção do caule com a raiz (Figura 6 A e B). Nas sementes pré-cultivadas por 5 dias, mais de $70 \%$ das áreas com expressão da GUS localizam-se nos cotilédones, preferencialmente distribuídas na face abaxial, provavelmente devido ao posicionamento dos cotilédones durante o co-cultivo 
com Agrobacterium. O lado abaxial não encontra-se em contato com o meio de cultura, que pode levar a uma diminuição localizada do $\mathrm{pH}$ do mesmo, facilitando desta forma, a indução dos genes vir como o observado nos trabalhos de Stachel et al., (1985) e Santarém et al., (1998). Por outro lado, sementes pré-cultivadas por 15 e 17 dias apresentaram aproximadamente $60 \%$ das regiões com expressão da GUS localizadas no primeiro par de folhas (Figura 6C). A susceptibilidade diferencial observada entre os tecidos pode estar associada à taxa de síntese de DNA e à intensidade de divisão celular dos tecidos nas fases de germinação e desenvolvimento das plântulas (Villemont et al., 1997).

Tabela 5. Efeito do pré-cultivo das sementes e da sonicação na eficiência de transformação, expressa pela porcentagem de explantes que apresentaram regiões com expressão da GUS. Os valores entre parênteses indicam o erro padrão da média. As letras indicam diferenças estatisticamente significativas avaliadas pelo teste de Student $(P<0,05)$.

\begin{tabular}{|c|c|c|c|c|c|c|}
\hline \multirow{2}{*}{$\begin{array}{l}\text { Dias de } \\
\text { Pré- } \\
\text { cultivo }\end{array}$} & \multicolumn{2}{|c|}{ Controle } & \multicolumn{2}{|c|}{ Sonicadas } & \multirow{2}{*}{\multicolumn{2}{|c|}{$\begin{array}{l}\text { Taxa } \\
\text { Média }\end{array}$}} \\
\hline & $\begin{array}{c}\text { Taxa de } \\
\text { transformação }\end{array}$ & $\begin{array}{c}\text { Grau de } \\
\text { transformação }\end{array}$ & $\begin{array}{c}\text { Taxa de } \\
\text { transformação }\end{array}$ & $\begin{array}{l}\text { Grau de } \\
\text { transformação }\end{array}$ & & \\
\hline 0 & $2,17(1,53)$ & $2,0(1,0)$ & $4,02(1,52)$ & $2,0(1,0)$ & $3,09(2,2)$ & $c$ \\
\hline 2 & $14,0(4,0)$ & $4,18(1,93)$ & $21,72(0,72)$ & $5,93(0,33)$ & $17,86(2,7)$ & $\mathrm{cb}$ \\
\hline 5 & $1,51(1,51)$ & $1,5(1,5)$ & $5,54(2,34)$ & $2,83(1,83)$ & $3,53(1,2)$ & $\mathrm{c}$ \\
\hline 15 & $17,14(2,86)$ & $1,12(0,12)$ & $37,38(6,61)$ & $2,27(0,27)$ & $27,26(6,4)$ & $\mathrm{a}$ \\
\hline 17 & $11,0(1,9)$ & $1,12(0,12)$ & $19,54(1,89)$ & $4,0(1,0)$ & $15,27(2,9)$ & $\mathrm{b}$ \\
\hline Médias & $9,19(1,44) \mathrm{b}$ & & $17,64(2,66) \mathrm{a}$ & & & \\
\hline
\end{tabular}




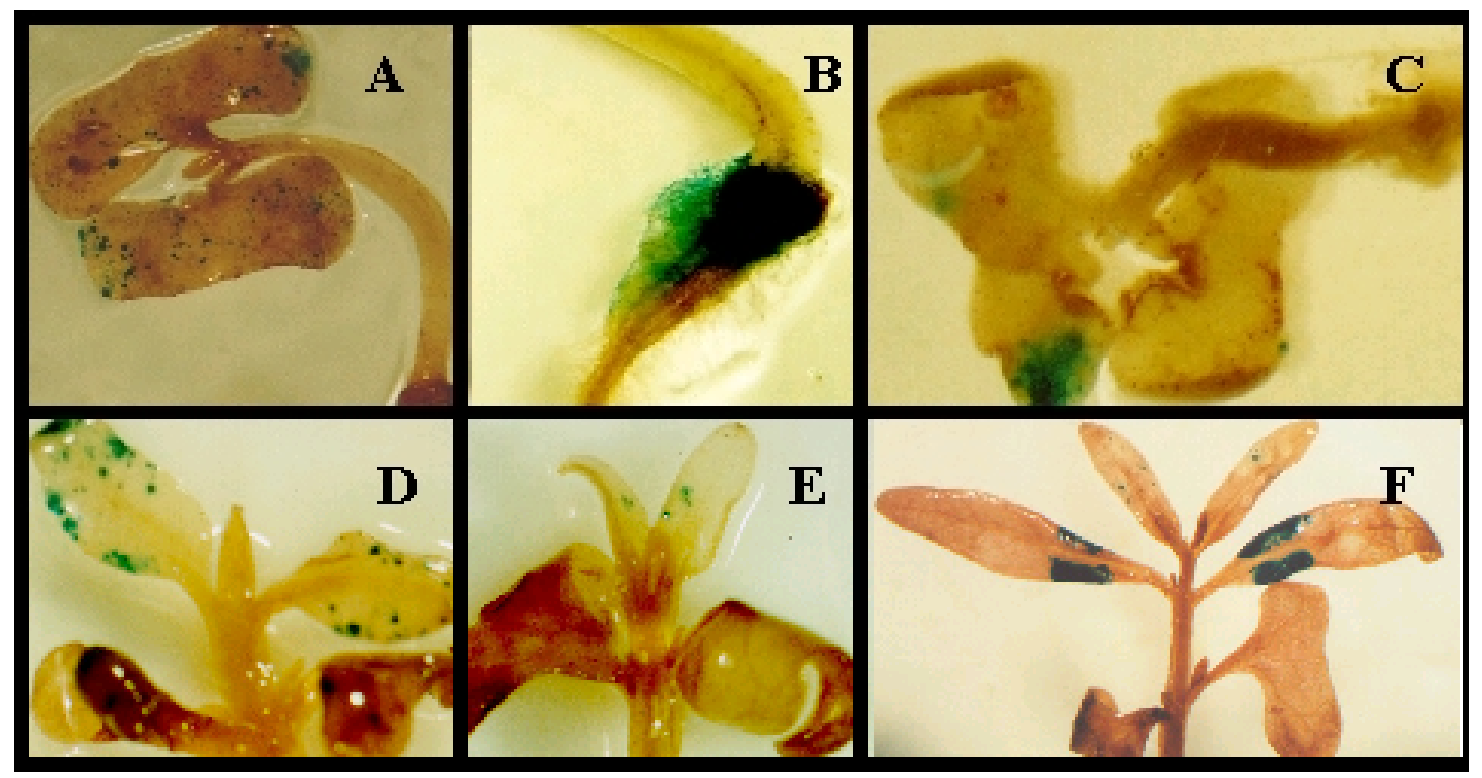

Figura 6 - Expressão transitória da ß-glucuronidase (GUS) em cotilédones (A e C) e na intersecção do hipocótilo com a raiz (B) de sementes pré-cultivadas por 2 dias e folhas primárias de plântulas pré-cultivadas por 15 dias (D-F), submetidas à infecção com $A$. tumefaciens, assistida pela técnica de sonicação.

\subsubsection{Efeito do tempo de sonicação na eficiência de transformação}

Um dos fatores que afetam a eficiência de transformação com Agrobacterium assistida pela sonicação é o tempo de exposição da mesma, que pode ser realizada, antes ou durante a inoculação com a bactéria. Trick \& Finer (1997), testaram tempos de 1 a 100 segundos e observaram que a presença de microferimentos aumentava proporcional ao tempo de duração da sonicação, embora um tempo prolongado cause danos nos tecidos, prejudicando assim, a posterior regeneração dos mesmos (Joerdbo \& Brunstedt, 1992). 
Neste experimento, avaliou-se o efeito da variação do tempo de sonicação antes e durante a inoculação. Os tratamentos foram organizados de forma fatorial, sendo o fator 1, a duração da sonicação antes da inoculação e tempos avaliados foram 0, 30, 60, 90 e 120 segundos. O fator 2 avaliado, foi o efeito da duração da sonicação durante a inoculação, sendo considerados os tempos 0,15 e 30 segundos. Os resultados apresentaram uma variação na eficiência de transformação entre 15,3 e 37,2 \% (Tabela 6). À análise estatística mostrou interação significativa entre os fatores, e a comparação de médias foi realizada dentro de cada tempo de sonicação durante a inoculação em relação aos diferentes tempos de sonicação anteriores à inoculação. Foram encontradas diferenças estatisticamente significativas dentro dos tratamentos que não foram sonicados durante a inoculação (Tabela 6). Neste caso, o melhor resultado obtido foi o de $37,2 \%$ quando as sementes foram sonicadas durante 120 segundos, no entanto, as sementes controle (não sonicadas) apresentaram uma taxa de transformação de 15,3\% (Tabela 6). Entretanto, na avaliação do efeito da sonicação durante a inoculação não foram observadas diferenças estatisticamente significativas entre os tratamentos.

Trick \& Finner (1997), sugerem que o tempo de sonicação utilizado nos experimentos deve ser suficiente para se obter a maior eficiência de transformação, tendo-se o cuidado de que os danos causados nos tecidos não afetem o processo de regeneração dos mesmos. Em nossas condições de trabalho, a sonicação por $120 \mathrm{~s}$ não afetou significativamente a viabilidade dos cotilédones quando estes foram transferidos para os meios de regeneração (dados não apresentados). Estes resultados indicam que a intensidade de $40 \mathrm{kHz}$, utilizada no experimento foi apropriada, considerando que a utilização de intensidades muito altas, podem causar lise e consequentemente, morte das células, influenciando assim o processo de regeneração dos tecidos submetidos a esse tipo de tratamento (Joersbo \& Brunstedt, 1992). 
Tabela 6. Efeito do tempo de sonicação na eficiência de transformação de sementes via Agrobacterium. A transformação foi avaliada e expressa em porcentagem de explantes que apresentavam áreas com expressão da GUS. Os dados obtidos referem-se às médias de 5 repetições. Os valores entre parênteses correspondem ao erro padrão da média. Letras diferentes indicam diferenças estatisticamente significativas, de acordo com o teste Tukey $(P<0,05)$, sendo que as comparações foram feitas dentro de cada coluna.

\begin{tabular}{cccc}
\hline \multirow{2}{*}{$\begin{array}{c}\text { Tempo de sonicação } \\
\text { anterior à inoculação }\end{array}$} & \multicolumn{3}{c}{ Tempo de sonicação durante a inoculação (s) } \\
\cline { 2 - 4 }$(\mathrm{s})$ & 0 & 15 & 30 \\
\hline 0 & $15,3(3,2) \mathrm{b}$ & $25,8(2,2) \mathrm{a}$ & $18,4(3,2) \mathrm{a}$ \\
30 & $24,6(3,7)$ ab & $23,4(6,8) \mathrm{a}$ & $28,9(5,0) \mathrm{a}$ \\
60 & $29,4(1,4)$ ab & $27,5(3,6) \mathrm{a}$ & $29,6(3,1) \mathrm{a}$ \\
90 & $27,4(2,1) \mathrm{ab}$ & $22,9(2,9) \mathrm{a}$ & $27,1(4,0) \mathrm{a}$ \\
120 & $37,2(3,8) \mathrm{a}$ & $30,8(1,8) \mathrm{a}$ & $16,7(1,7) \mathrm{a}$ \\
\hline
\end{tabular}

\subsubsection{Influência dos diferentes meios e condições de luminosidade durante o co- cultivo na eficiência de transformação}

Neste experimento foi testado o efeito dos diferentes meios e condições de luminosidade durante o co-cultivo na eficiência de transformação. Os tratamentos foram distribuídos de forma fatorial, sendo avaliados como fator 1 , os diferentes meios de cocultivo, e como fator 2, as condições de luminosidade (escuro e com fotoperíodo). Os meios avaliados foram: MA, MM, ME, MS, M2, M8, M9 e M10 (Tabela 4). A eficiência 
de transformação nos diferentes tratamentos apresentou valores entre 16,9 e 49,5 \% (Tabela 7). A análise estatística não indicou interação entre os fatores avaliados pelo que a comparação de médias foi feita entre os fatores individuais.

O efeito das condições de luminosidade (escuro e fotoperíodo) não apresentou diferenças estatisticamente significativas entre as médias. Já o fator 1, referente aos meios de co-cultivo, sim. Neste caso, a melhor média $(45,5 \%)$ foi obtida com o meio MS, em contraste com a de 17,2 \% para o meio de co-cultivo M2 (Tabela 7). Estes resultados contradizem trabalhos que mostram o efeito positivo dos reguladores de crescimento no processo de transferência gênica em Arabidopsis thaliana (Akama et al., 1992; Sangwan et al., 199), maçã (Bondt et al., 1994), beterraba (Jacq et al., 1993), kiwi (Janssen \& Gardner, 1993) e Astragulus sinicus (Li et al., 1992;). A alta taxa de transformação encontrada quando foi utilizado o meio MS desprovido de reguladores de crescimento pode ser devida à alta taxa de divisão celular das sementes em germinação, que leva a uma maior susceptibilidade à Agrobacterium (Villemont et al., 1997). Nas nossas condições de trabalho os reguladores de crescimento podem ter influenciado na germinação das sementes, relacionada a uma menor taxa de divisão celular, o que explica as menores taxas de transformação encontradas nos meios contendo reguladores de crescimento.

Inicialmente pensávamos que o efeito da ausência de luz poderia induzir um aumento da susceptibilidade dos explantes à Agrobacterium, devido ao fato dos explantes estiolados possuírem paredes celulares e cutículas mais delgadas (Zhang et al., 1997). No entanto, não observamos diferenças estatisticamente significativas entre os tratamentos de escuro e fotoperíodo. 
Tabela 7. Efeito dos diferentes meios e condições de luminosidade durante o co-cultivo, na eficiência de transformação. Os dados são médias de 5 repetições e estão expressos em porcentagem de explantes que apresentaram ao menos uma região com expressão da GUS. Valores entre parênteses referem-se ao erro padrão da média, e as letras indicam diferenças significativas avaliadas pelo teste de Tukey $(P<0,05)$.

\begin{tabular}{|c|c|c|c|}
\hline \multirow[b]{3}{*}{ Meios } & \multicolumn{2}{|c|}{ Eficiência de transformação (\%) } & \multirow[b]{3}{*}{$\underline{\text { Médias }}$} \\
\hline & \multicolumn{2}{|c|}{ Luminosidade } & \\
\hline & $16 \mathrm{~h} \mathrm{Luz}$ & Escuro & \\
\hline MM & $37,2(3,5)$ & $36,6(5,3)$ & $36,9 \mathrm{~b}$ \\
\hline EM & $36,4(3,1)$ & $35,3(3,2)$ & $35,9 \mathrm{ab}$ \\
\hline M10 & $19,6(3,4)$ & $17,7(1,6)$ & 18,7 de \\
\hline MS & $49,5(4,7)$ & $41,4(3,1)$ & $45,5 \mathrm{a}$ \\
\hline RM & $36,1(1,0)$ & $27,1(4,3)$ & $31,6 \mathrm{bc}$ \\
\hline M9 & $24,6(2,8)$ & $17,6(3,6)$ & 21,1 cde \\
\hline M8 & $25,8(2,4)$ & $33,9(1,4)$ & 29,9 bcd \\
\hline M2 & $16,9(1,3)$ & $18,1(1,6)$ & $17,5 \mathrm{e}$ \\
\hline Médias & 30,9 a & $28,5 \mathrm{a}$ & \\
\hline
\end{tabular}

M2 (MB contendo $2 \mu \mathrm{M}$ ANA e $2 \mu \mathrm{M}$ de TDZ), M8 (MB contendo $0,44 \mu \mathrm{M}$ BA e 5,5 $\mu \mathrm{M}$ NAA), M9 (MB contendo $100 \mathrm{ml}$ água de côco), M10 (MB contendo 0,44 $\mu \mathrm{M}$ BA e 2,25 $\mu \mathrm{M}$ 2,4D). 


\subsubsection{Tolerância de $\boldsymbol{E}$. grandis a diferentes agentes seletivos}

A eficiência de transformação de uma determinada espécie está intimamente relacionada ao sistema de seleção dos transformantes. Este deve, inibir o desenvolvimento das células não transformadas, de forma diferencial permitindo que somente as transformadas, se desenvolvam e formem brotações. Exemplos do uso da canamicina na seleção de plantas transgênicas em diferentes espécies arbóreas, são encontrados para o caso de Liquidamber styraciflua L. (Sullivan \& Lagrimini, 1993), Populus tremuloides Michx. (Tsai et al., 1994) e Prunus dulcis Mill. (Archilletti et al., 1995). Já em outros trabalhos, a geneticina foi utilizada com sucesso na obtenção de plantas transgênicas de arroz (Dekeyser et al., 1989) e Arabidopsis thaliana L. (Schimidt \& Willmitzer, 1988).

Neste experimento, avaliamos o efeito dos antibióticos geneticina e canamicina, sobre o grau de tolerância dos tecidos transformados, em diversas fases da regeneração. Foram realizados os seguintes tratamentos: controle (ausência do agente seletivo), canamicina, nas concentrações de, 50 e 100 mg.L $\mathrm{L}^{-1}$ e geneticina G418 nas concentrações de, 2,5; 5 e 10 mg.L $\mathrm{L}^{-1}$. Os parâmetros avaliados foram: mortalidade dos explantes após 30 dias (Figura 7), capacidade de regeneração de calos após 45 dias (Figura 8), formação de brotos após 60 dias (Figura 9) e expressão da GUS nos calos, após 70 dias (Figura $10)$.

Sementes inoculadas e co-cultivadas com A. tumefaciens foram transferidas e mantidas por 20 dias em meio MS sólido até o desenvolvimento das plântulas. Uma amostra representada por 50 plântulas foi avaliada quanto à atividade da GUS, das quais $42 \%$ apresentaram, pelo menos, uma região com coloração azulada nos cotilédones. 


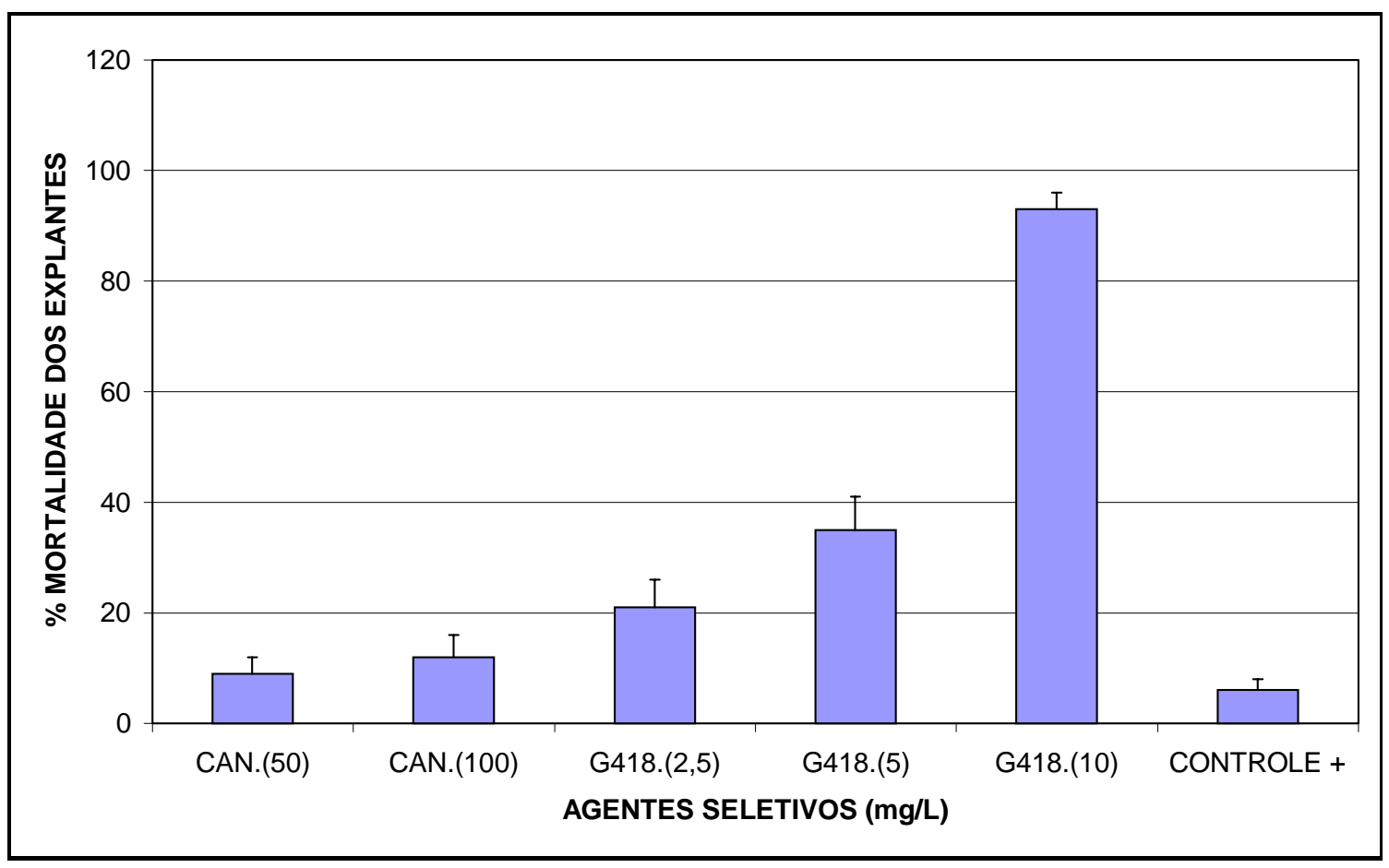

Figura 7 - Taxa de mortalidade (\%), após 30 dias de exposição aos agentes seletivos. Canamicina (can) e geneticina G418 (G418). Média de quatro repetições, com barras indicando o erro padrão da média.

Os resultados apresentados na Figura 7 indicam que a geneticina tem um efeito drástico sobre a sobrevivência dos explantes. Esta alta toxicidade da geneticina foi considerada em trabalhos com Beta vulgaris L. (Catlin, 1990) e maçã (Norelli \& Aldwinckle, 1993) como sendo um efeito negativo para a seleção de tecidos transformados. Já com relação à canamicina, os explantes são bastante tolerantes fato que foi também observado em outras espécies vegetais (Wilmink et al., 1995; Wilmink \& Dons, 1993).

Os explantes mantidos por 30 dias no escuro (etapa de indução de calos) foram transferidos para luz (etapa de formação de brotos), mantendo-se as respectivas concentrações dos antibióticos. A Figura 8, mostra uma forte inibição da formação de calos na presença de canamicina. Já a geneticina, embora tenha apresentado uma maior taxa de mortalidade dos explantes, os que resistiram à presença desse antibiótico, 
tiveram maior capacidade de formação de calos quando comparados aos provenientes dos tratamentos com canamicina.

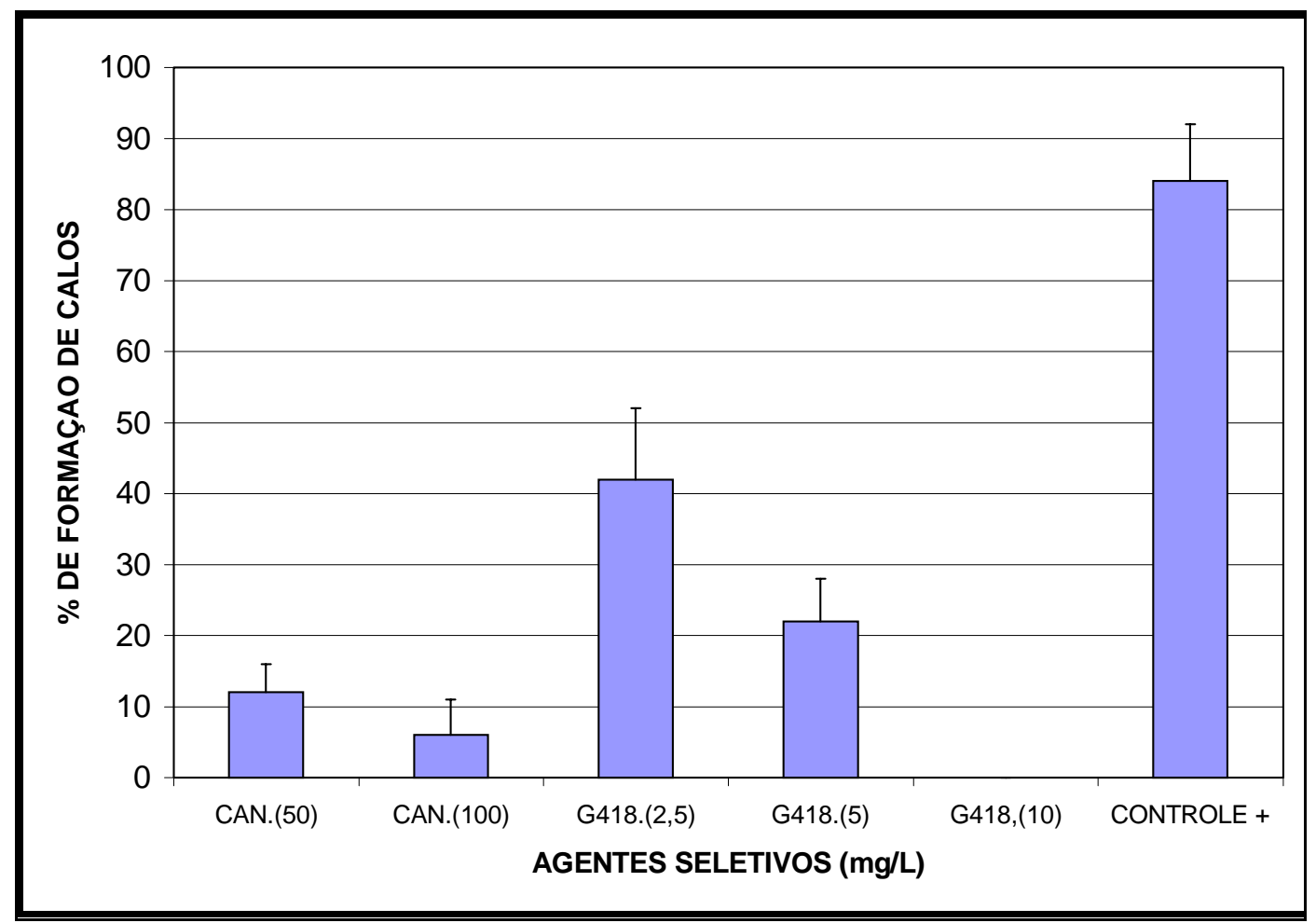

Figura 8 - Taxa de formação de calos (\%) após 45 dias de exposição aos agentes seletivos. Canamicina (can) e geneticina G418 (G418). Média de quatro repetições, com barras indicando o erro padrão da média.

A Figura 9 apresenta as taxas de formação de brotos, após 60 dias de exposição aos agentes seletivos. Observou-se que em baixas concentrações de geneticina, as taxas de formação de brotos foram maiores quando comparadas às concentrações de canamicina, que inibiram drasticamente a formação dos mesmos. Observamos que do total de 31 calos formados, nos tratamentos com canamicina, somente um desenvolveu brotações. Este efeito de inibição da capacidade morfogenética foi observado também em girassol onde, calos transgênicos selecionados em canamicina, apresentavam forte inibição no desenvolvimento de brotações (Everett et al., 1987). 
No tratamento com 10 mg.L $\mathrm{L}^{-1}$ de geneticina G418, somente 5 calos sobreviveram, mas não foram capazes de formar brotos, morrendo antes de um período de 80 dias de exposição. O que mostra que $10 \mathrm{mg} . \mathrm{L}^{-1}$ de geneticina é uma concentração muito elevada para a seleção do material transformado.

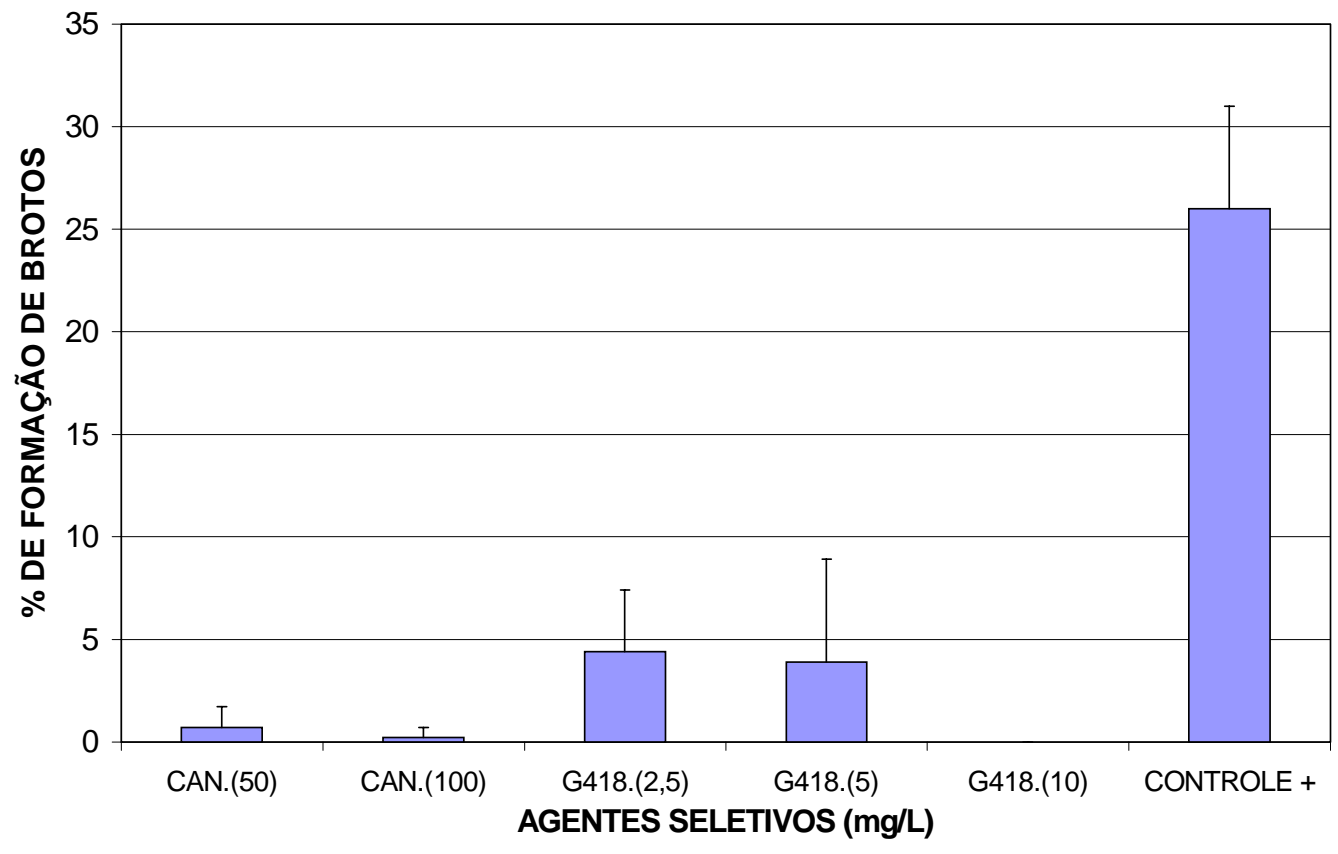

Figura 9 - Taxa de formação de brotos (\%) após 60 dias de exposição aos agentes seletivos. Canamicina (can) e geneticina G418 (G418). Média de quatro repetições, com barras indicando o erro padrão da média.

A atividade da GUS, foi avaliada nas amostras de tecidos de cada tratamento, após 70 dias de exposição aos agentes seletivos. Pelos resultados apresentados na Figura 10 pode-se observar, que os tecidos transformados tiveram um melhor desenvolvimento nos tratamentos com canamicina. Já nos tratamentos com geneticina 2,5 mg.L ${ }^{-1}$, não há grandes diferenças com relação ao número de áreas transgênicas (com expressão da GUS), comparado ao controle (sem agente seletivo). 


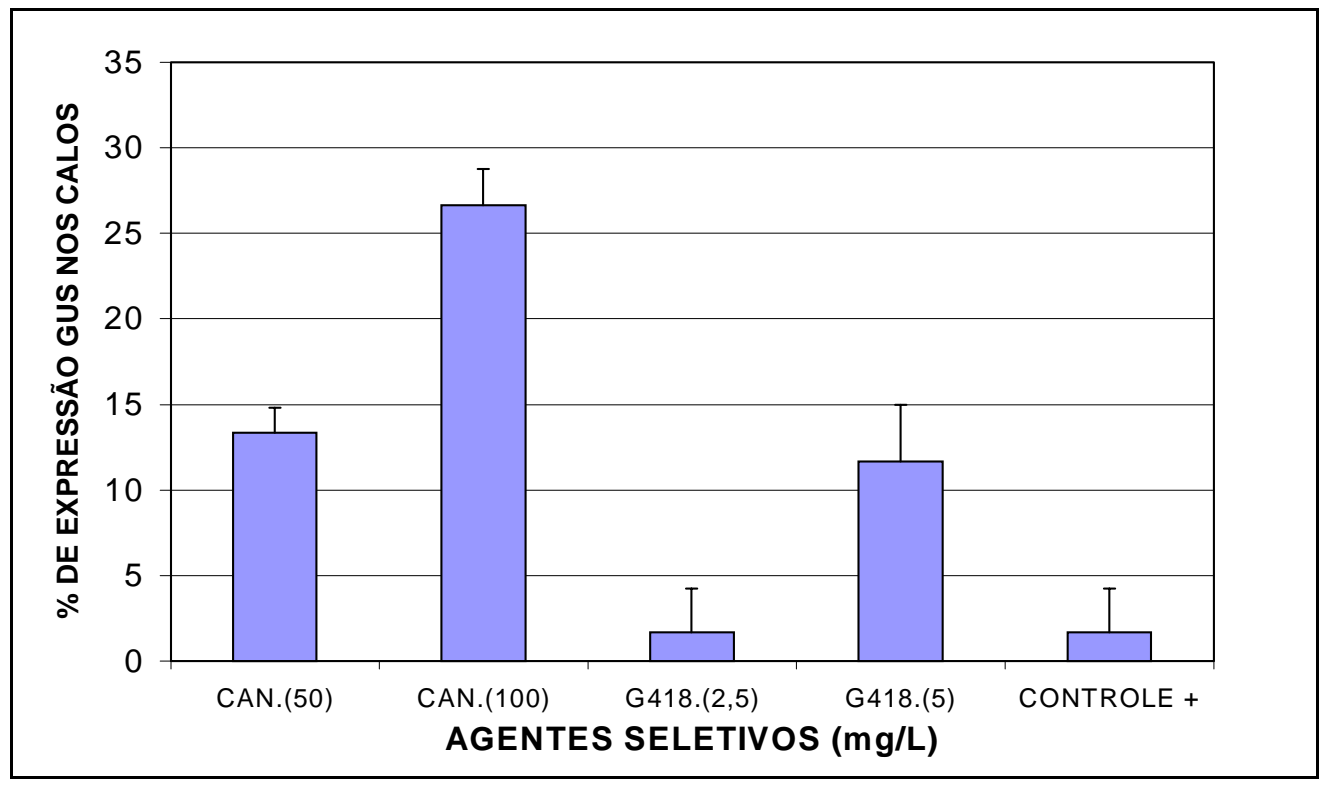

Figura 10 - Taxa de expressão da GUS (\%) nos explantes, após 70 dias de exposição aos agentes seletivos. Canamicina (Can) e geneticina (G418). Média de quatro repetições, com barras indicando o erro padrão da média.

Pela comparação entre os agentes seletivos, pode-se observar que a geneticina é mais eficiente, se considerarmos a taxa de mortalidade dos explantes. Entretanto, observamos que os explantes que não morreram, apresentaram formação de calos com grande quantidade de tecidos não transgênicos, o que dificulta o uso desse antibiótico como agente seletivo. Já a canamicina inibiu drasticamente a regeneração de calos e formação de brotos. Por outro lado, a porcentagem de calos transformados (com expressão da GUS) Figura 10 foi mais alta para a canamicina. Dos explantes que apresentaram desenvolvimento de brotações, apenas o calo desenvolvido em canamicina $50 \mathrm{mg}$. $\mathrm{L}^{-1}$ apresentou brotações com expressão da GUS (Figura 6).

Estes resultados confirmam a baixa eficiência de ambos os antibióticos na seleção de tecidos transformados de E. grandis. A espécie apresentou alta tolerância à canamicina mas a regeneração de calos transgênicos ficou comprometida, pois foi bastante inibida. Já, a geneticina G418, causou severas necroses dos explantes, 
ocasionando a morte rápida, embora na concentração de $2,5 \mathrm{mg}$. $\mathrm{L}^{-1}$ tenha permitido o aparecimento de escapes.

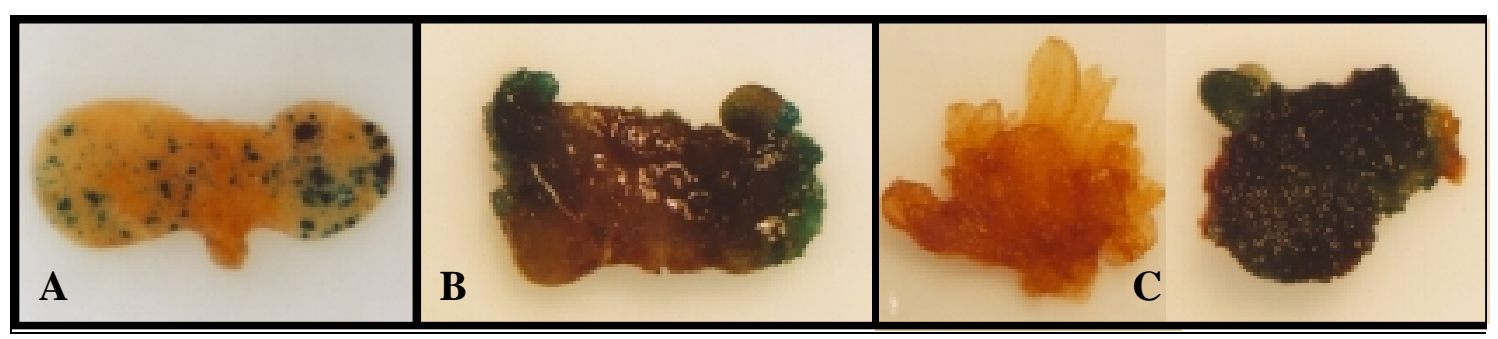

Figura 11 - Expressão transitória da $\beta$ - Glucuronidase (GUS). A) Explante com áreas de expressão da GUS. B) Explantes quiméricos formados após 30 dias em meio de formação de calos contendo $50 \mathrm{mg} \mathrm{L}^{-1}$ de canamicina. C) Formação de gemas transgênicas (esquerda) e controle (direita), após 70 dias em meio de cultura de calos acrescido de $50 \mathrm{mg} \mathrm{L}^{-1}$ de canamicina.

\subsubsection{Avaliação da eficiência de transformação de $E$. grandis, $E$. urophylla e do} híbrido E. grandis $x$ E. urophylla

Grande variabilidade, quanto à susceptibilidade à infecção por A. tumefaciens tem sido observada em várias espécies vegetais (Anderson \& Moore, 1979; Wordragen \& Dons, 1992). Embora algumas dessas diferenças na frequência de infecção sejam atribuídas a fatores ambientais ou fisiológicos, o efeito do genótipo é muito significativo na susceptibilidade em soja (Bailey et al., 1994; Mauro et al., 1995), Arabidopsis (Nam et al., 1997) e ervilha (Robbs et al., 1991).

Os resultados ilustrados na Figura 12 indicam que tanto E. grandis como $E$. urophylla e o híbrido entre ambos, são susceptíveis à A. tumefaciens. O híbrido apresentou uma taxa de transformação (52\%) superior às observadas para E. grandis (35 $\%)$ e E. urophylla (15\%). Estes resultados mostram uma forte influência do genótipo na taxa de transformação. Machado et al. (1997) também observaram grandes diferenças no desenvolvimento de tumores causados por A. tumefaciens em diferentes híbridos de 
Eucalyptus. Esmeraldo et al. (1997) observaram que o híbrido E. grandis $x$ E. urophylla é muito susceptível à infecção com A. tumefaciens.

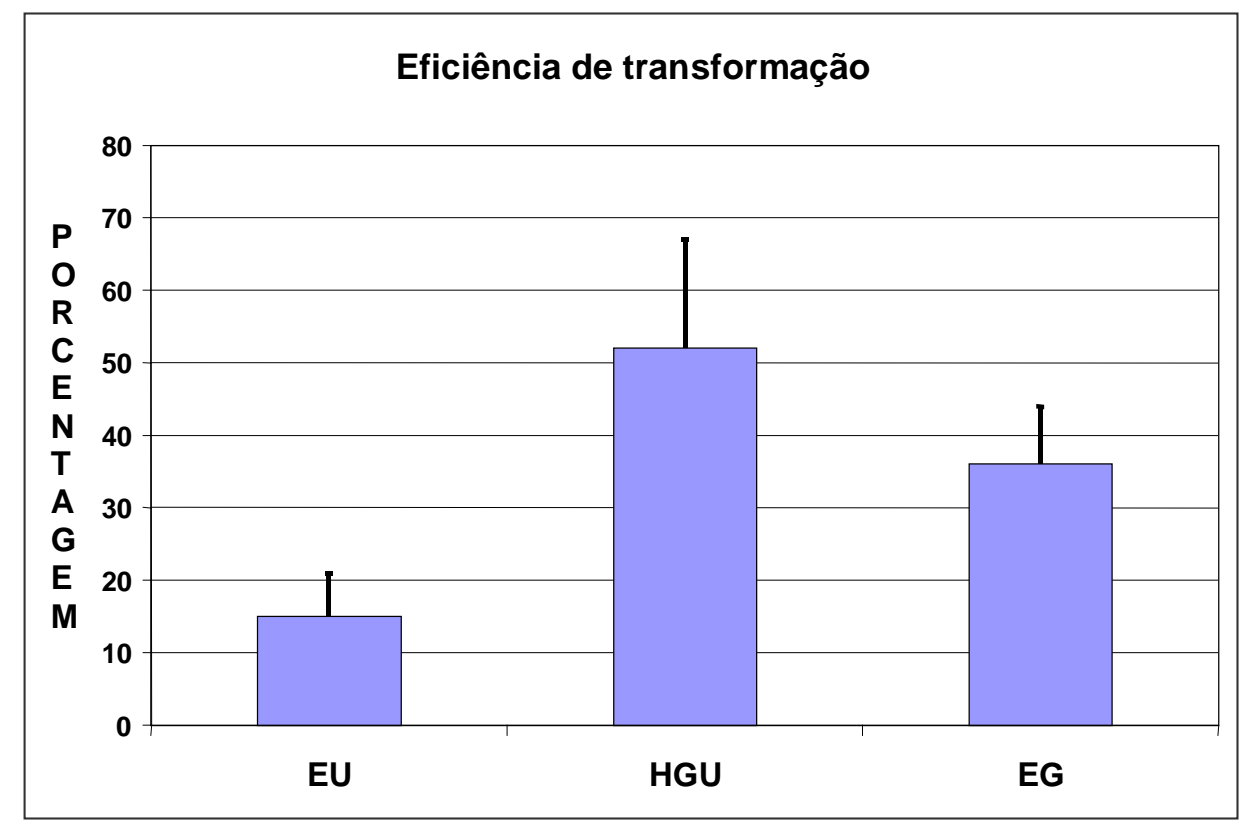

Figura 12 - Eficiência de transformação (\%) de E. grandis (EG), E. urophylla (EU) e do híbrido entre ambos (HGU), quanto à suscetibilidade à A. tumefaciens. Média de 6 repetições com as barras indicando o erro padrão da média.

\subsubsection{Seleção, regeneração e obtenção de plantas transgênicas do híbrido $E$. grandis $x$ E. urophylla com o gene quimérico Lhcb1 $* 2$}

Com as condições experimentais estabelecidas, montou-se um experimento com o objetivo de se obter plantas transgênicas de eucalipto com o gene quimérico Lhcbl *2, que codifica a proteína de $28 \mathrm{KDa}$, do complexo LHCIIb do sistema antena, associado ao PSII. As sementes foram pré-cultivadas por 2 dias, sonicadas por 120 segundos antes da inoculação e co-cultivadas por 48 h no meio MS. Após o co-cultivo, 2000 cotilédones foram excisados e transferidos para o meio de formação de calos $\mathrm{M} 1$, dos quais $50 \%$ foram mantidos neste meio acrescido de $50 \mathrm{mg} . \mathrm{L}^{-1}$ de canamicina e $50 \%$ no mesmo meio contendo $5 \mathrm{mg} . \mathrm{L}^{-1}$ de geneticina G418. Após 30 dias 182 calos haviam sido 
formados dos quais, 130 na presença de $5 \mathrm{mg} \mathrm{L}^{-1}$ de geneticina G418 e 52 em $50 \mathrm{mg} . \mathrm{L}^{-1}$ de canamicina..

Os calos foram então transferidos para o meio de desenvolvimento de brotações (M2), contendo os respectivos agentes seletivos e mantidos por 30 dias. Nestas condições, 2 calos selecionados em $5 \mathrm{mg} \mathrm{L}^{-1}$ de geneticina G418, apresentaram desenvolvimento de brotações, que após passarem pelos meios de multiplicação, alongamento e enraizamento, regeneraram 27 plantas. No entanto, os calos formados em canamicina não apresentaram desenvolvimento de brotações.

As plantas transgênicas putativas foram analisadas por Southern blot, através da hibridização com a sonda específica para o transgene. A Figura 13 ilustra a presença de 4 eventos independentes de transformação. A baixa eficiência de transformação observada para o caso, em comparação com a expressão transitória da GUS, foi principalmente devido ao forte efeito inibitório do agente seletivo, sobre a regeneração, sendo que a canamicina apresentou inibição completa do desenvolvimento de gemas.

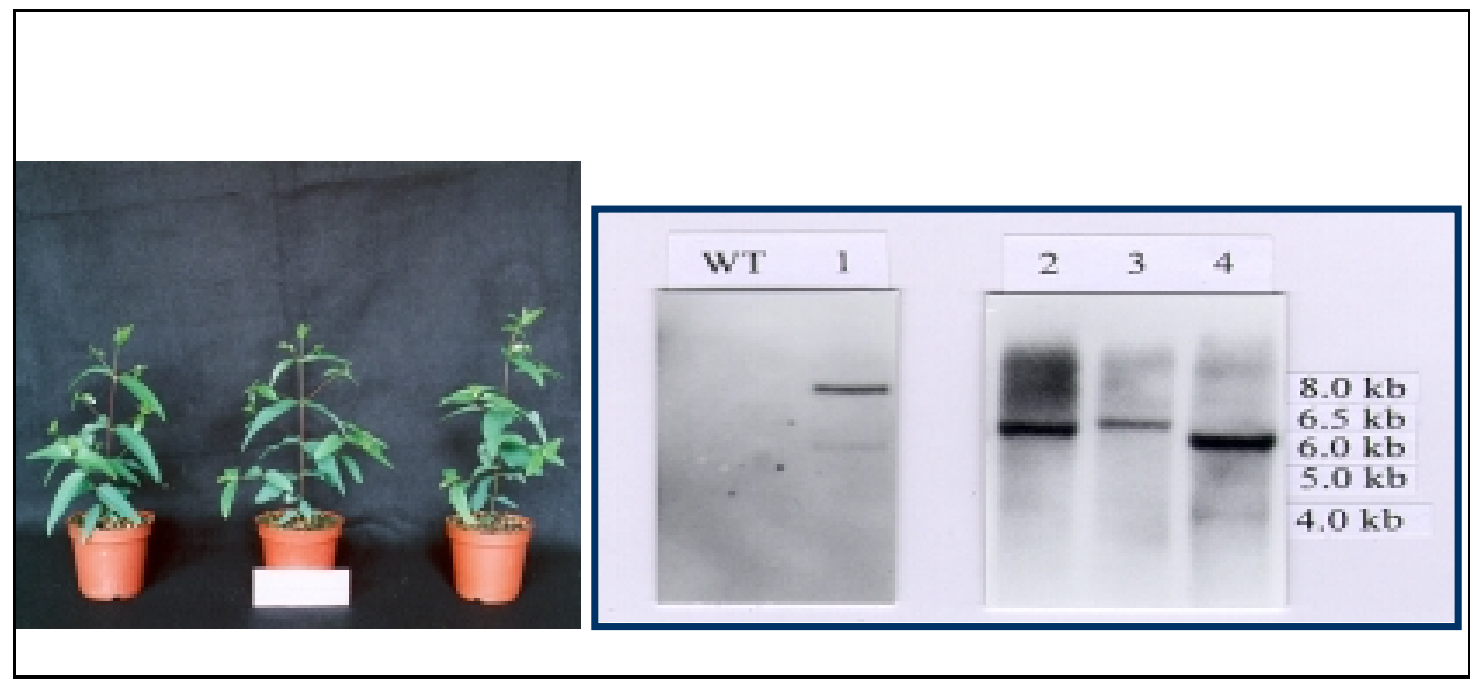

Figura 13 - Plantas transgênicas do híbrido E. grandis $x$ E. urophylla (esquerda). Southern blot (direita) dos transformantes primários. $10 \mu \mathrm{g}$ de DNA genômico total foi digerido com a enzima HindIII, separado por eletroforese e hibridizado com a sonda do gene nptII. Controle negativo (planta selvagem -WT) e transformantes (1, 2, 3 e 4 ). 


\subsubsection{Seleção, regeneração e obtenção de plantas transgênicas de $E$. grandis com o gene marcador uidA}

Montou-se um experimento com o objetivo de provar-se a eficiência do sistema de transformação em E. grandis através da obtenção de plantas transgênicas com o gene marcador uidA que codifica a enzima $\beta$-Glucuronidase. As sementes foram précultivadas por 2 dias, sonicadas por 120 segundos, antes da inoculação e co-cultivadas por 48 h no meio MS. Após o co-cultivo, 2000 cotilédones foram cortados e transferidos para o meio de formação de calos M1 por 30 dias no escuro, sendo que $50 \%$ foram mantidos no meio contendo $50 \mathrm{mg} . \mathrm{L}^{-1}$ de canamicina e $50 \%$ no meio acrescido de 5 mg. $\mathrm{L}^{-1}$ de geneticina G418, após esse período foram obtidos um total de 112 calos. Deste total, 47 desenvolveram-se na presença de $5 \mathrm{mg} \mathrm{L}^{-1}$ de geneticina G418, e 65 em 50 mg. $\mathrm{L}^{-1}$ de canamicina.

Os calos foram posteriormente transferidos para o meio de desenvolvimento de brotações M2 (contendo os respectivos agentes seletivos) e mantidos por 30 dias. Após esse período, 6 calos selecionados em geneticina G418 apresentaram desenvolvimento de brotações. No entanto, do total de calos formados em meio contendo canamicina, somente 1 apresentou desenvolvimento de brotações. Os calos contendo as brotações, após passarem pelos meios de multiplicação, alongamento e enraizamento regeneraram 64 plantas, sendo que 22 foram regeneradas do calo selecionado em canamicina e 42 dos calos selecionados em geneticina.

Pelo teste histológico da GUS nas folhas e raízes das plantas que regeneraram, observou-se que as 42 plantas provenientes da seleção em geneticina G418 não apresentaram expressão da enzima. Já, as 22 plantas regeneradas na presença de canamicina apresentavam expressão GUS estável como ilustrado na Figura 14. Esses transformantes putativos foram analisados pela técnica de Southern blot, que confirmou a presença do transgene inserido de forma estável no genoma (Figura 15). A baixa 
eficiência de transformação observada em comparação com a alta taxa de expressão transitória da GUS, é decorrente principalmente do forte efeito inibitório do agente seletivo, como observado no experimento anterior. No caso da geneticina G418 na concentração de $5 \mathrm{mg} . \mathrm{L}^{-1}$, a seleção permitiu o aparecimento de escapes, ou seja, plantas que regeneraram na presença do antibiótico, mas não eram transformadas, provavelmente relacionado à alta tolerância da espécie E. grandis a esse antibiótico.

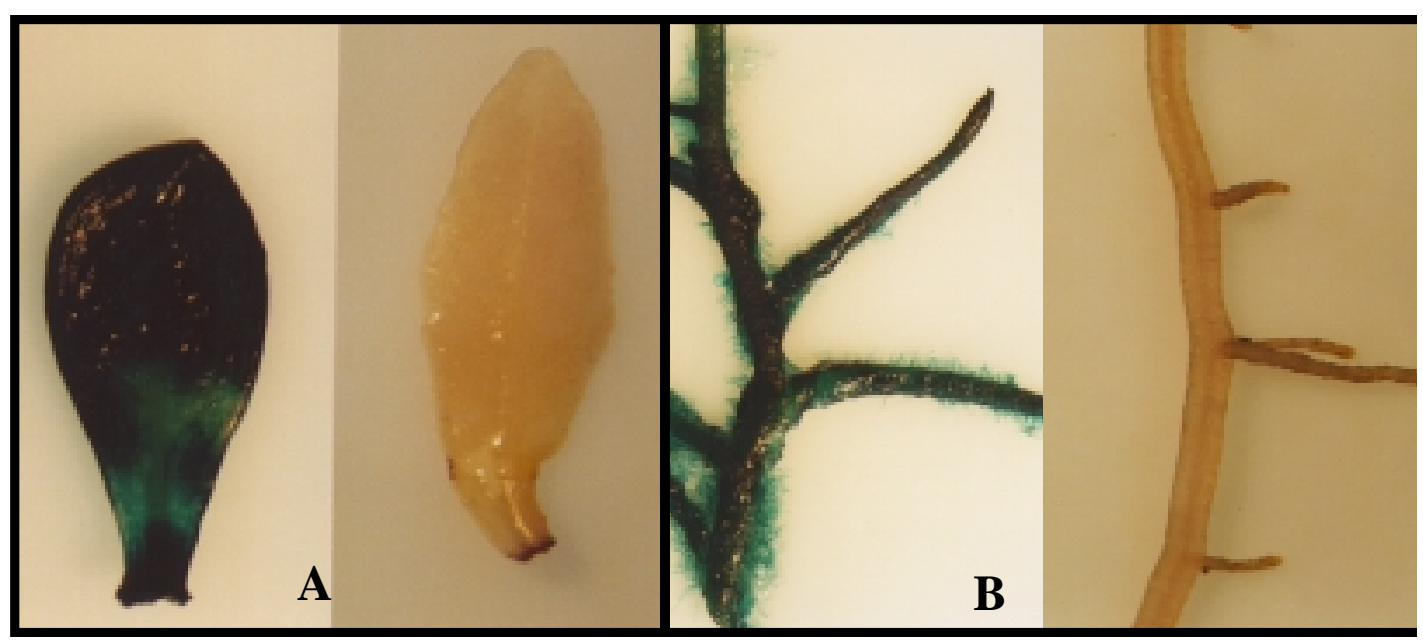

Figura 14 - Expressão histológica da GUS em folhas (A) e raízes (B) transgênicas (esquerda) e controle (direita). 


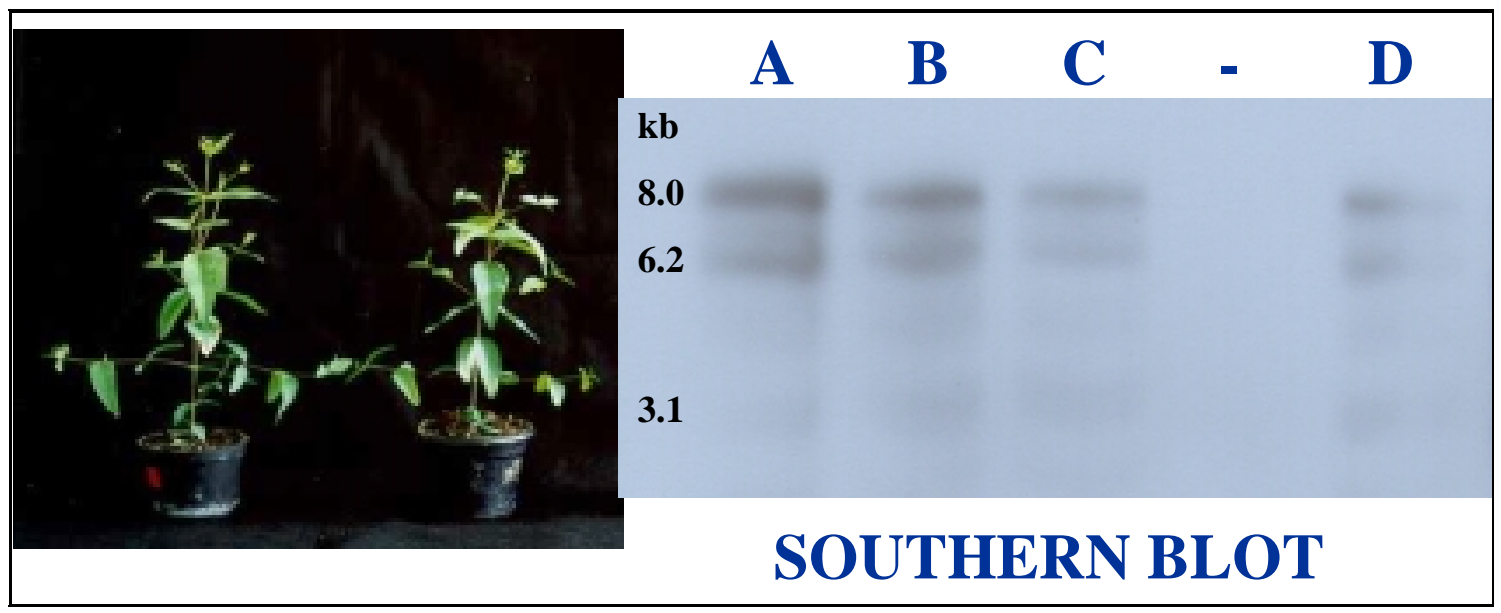

Figura 15 - Plantas transgênicas de E. grandis (esquerda). Southern blot (direita) dos transformantes primários. $10 \mu \mathrm{g}$ de DNA genômico total foi digerido com a enzima HindIII, separado por eletroforese e hibridizado com a sonda do gene nptII. Controle negativo (-) e transformantes (A, B, C e D).

\subsection{Conclusões}

A transformação estável de plantas de E. grandis e do híbrido E. grandis x $E$. urophylla foi obtida através da inoculação de sementes com A. tumefaciens. A eficiência de transformação está intimamente relacionada as etapas da germinação. A sonicação melhora a eficiência de transformação principalmente quando aplicada antes da inoculação. Ambos os agentes seletivos, geneticina G418 e canamicina, apresentaram forte efeito inibitório, limitando a formação de calos e brotos. Portanto, a principal vantagem deste sistema de transformação de sementes está na possibilidade de se realizar experimentos com um número grande de explantes, de forma a minimizar as perdas na eficiência do processo de seleção. 


\section{CONCLUSÕES GERAIS}

- Os sistemas de regeneração por organogênese indireta de cotilédones e folhas de plântulas foram obtidos, e apresentaram uma eficiência ao redor de 30 e $25 \%$ respectivamente.

- O protocolo de regeneração de plantas a partir de folhas de clones comerciais de $E$. grandis foi estabelecido por organogênese indireta.

- Estabeleceu-se um sistema de transformação de sementes capaz de transformar eficientemente cotilédones.

- A eficiência do processo de transformação de cotilédones aumenta quando a sonicação é de 120 s e o meio de co-cultivo é o MS.

- As condições de transformação, regeneração e seleção de cotilédones permitem a obtenção de plantas transgênicas de E. grandis e E. grandis X E. urophylla. 


\section{REFERÊNCIAS BIBLIOGRÁFICAS}

ADAM, S.; CHRIQUI, D.; CAISSARD, J.C. Transformation genetique et regeneration de bourgeons transgeniques chez Eucalyptus globulus. In: Biotechnologies appliquees aux arbres forestiers. Paris: AFOCEL, 1992. p.81-110.

AKAMA, A.; SHIRAISHI, H; OTHA, S; NAKAMURA, K; OKADA, K; SHIMURA, Y. Efficient transformation of Arabidopsis thaliana: comparisons of the efficiencies with various organs, plant eotyoe and Agrobaterium strains. Plant Cell Reports, v.12, p.7-11, 1992.

ANDERSON, A.R.; MOORE, L.W. Host specificity in the genus Agrobacterium. Phytopathology, v.69, n.4, p.320-323, 1979.

ARCHILlETTI, T.; LAURI, P.; DAMIANO, C. Agrobacterium mediated transformation of almond leaf pices. Plant Cell Reports, v.14, p.267-272, 1995.

AZMI, A.; DEWITTE, W.; DREVET, C.; VANONCKELEN, H.; LANDRE, P.; BOUDET, A.M.; JOUANIN, L.; CHRIQUI, D. Bud regeneration from Eucalyptus globulus clones and seedlings through hormonal imbalances induced by Agrobacterium tumefaciens strain 82.139. Plant Science, v.127, n.1, p.81-90, 1997.

BAILEY, M.A.; BOERMA, H.R.; PARROTT, W.A. Inheritance of Agrobacteriumtumefaciens-induced tumorigenesis of soybean. Crop Science, v.34, n.2, p.514-519, 1994. 
BANDYOPADHYAY, S.; CANE, K.; RASMUSSEN, G.; HAMILL, J.D. Efficient plant regeneration from seedling explants of two commercially important temperate eucalypt species Eucalyptus nitens and Eucalyptus globulus. Plant Science, v.140, n.2, p.189-198, 1999.

BARROS, L.G.M.; CARNEIRO, V.T.C. Electoporação de protoplastos. In: BRASILEIRO, A.C.M.; CARNEIRO, V.T.C. (Ed.). Manual de transformação genética de plantas. Brasília: EMBRAPA, SPI, 1998. cap.2, p.35-49.

BARRUETO CID, L.P.; ILLG, R.D.; PIEDRABUENA, A.E. Regeneration of garlic plants (Allium sativum L., cv. 'chonan') via cell culture in liquid medium. In Vitro Cellular and Developmental Biology, v.30, p.150-155, 1994.

BARRUETO CID, L.P.; GOMES, A.C.M.; COSTA, S.B.R.; BRASILEIRO, A.C.M. Plant regeneration from seedling explants of Eucalyptus grandis X E. urophylla. Plant Cell Tissue and Organ Culture, v.56, p.17-23, 1999.

BARRUETO CID, L.P.; GOMES, A.C.M.; COSTA, S.B.R.; TEIXEIRA, J.B. Micropropagation of Miconia sp, a woody Melastomaceae from Brazil, using thidiazuron as plant grow regulator. Revista Brasileira de Fisiologia Vegetal, v.9, p.21-25, 1997.

BENNETT, I.J.; MCCOMB, J.A. Propagation of jarrah (Eucalyptus marginata) by organ and tissue culture. Australian Forest Research, v.12, n.2, p.121-127, 1982.

BERTOLUCCI, F.; REZENDE, G.; PENCHEL, R. Produção e utilização de híbridos de eucalipto. Silvicultura, v.51, p.12-16, 1995.

BIDNEY, D.; SCELONGE, C.; MARTICH, J.; BURRUS, M.; SIMS, L.; HUFFMAN, G. Microprojectile bombardment of plant tissues increases transformation frequency by Agrobacterium tumefaciens. Plant Molecular Biology, v.18, n.2, p.301-313, 1992. 
BINGHAM, E.; HURLEY, L.; KATZ, D.; SAUNDERS, J. Breeding alfalfa which regenerates from callus tissue in culture. Crop Science, v.15, p.719-720, 1975.

BLOCK, M.D. The cell biology of plant transformation: current state, problems prospects and the implications for plant breeding. Euphytica, v.71, p.1-14, 1993.

BOLTRON, G. W.; NESTER, E. W.; GORDON, M. P. Plant phenolic compounds indisce expretion of A. tumefaciens loci needed for virulence. Science, v.232, p.983985, 1986.

BONDT, A. D.; EGGERMONT, K.;DRUART, P.;VIL, M. D.;GODERIST, I.; VANDERLEYDEN, J.; BROEKAERT, E. Agrobacterium-mediated transformation of apple (Malus domestica Borkh.): an assessment of factors affecting gene transfer efficiency during early transformation stepps. Plant Cell Reports, v.13, p.587-593, 1994.

BRACELPA. Avaliação do setor de celulose e papel. http://www.bracelpa.com.br. (Janeiro, 2002)

CAPLAN, A.; HERRERA-ESTRELLA, L.; INZE, D.; VAN HAUTE, E.; VAN MONTAGU, M.; SHELL, J.; ZAMBRYSKI, P. Introductions of genetic material in plant cells. Science, v.222, p.815-821, 1983.

CARR, S. G. M.; CARR, D. J.; ROSS, F. L. Male flowers in eucalypts. Australian Journal of Botany, v.19, p.73-83, 1971

CASHMORE, A.R. Structure and expression of a pea nuclear gene encoding a chlorophyll a/b binding polypeptide. Proceedings National Academy Sciences USA, v.81, p.2960-2964, 1984. 
CATLIN, D. W. The efect of antibiotics on the inibition of callus induction and plant regeneration from cotyledons of sugarbeet (Beta vulgaris L.). Plant Cell Reports, v.9, p.285-288, 1990.

CHALUPA, V. Effect of benzylaminopurine and thidiazuron on in vitro shoot proliferation of Tilia cordata Mill., Sorbus aucuparia L. and Robinia pseudoacacia L. Physiologia Plantarum, v.29, p.425-449, 1987.

CHANG, S.H.; YANG, J.C. Callus culture and regeneration of Eucalyptus camaldulensis (in Chinese). Bulletin Taiwan Forestry Research Institute New Service, v.10, p.15-24, 1995.

CHEE, P.P.; FOBER, K.A.; SLIGHTOM, J.L. Transformation of soybean (Glycine max) by infecting germinating seeds with Agrobacterium tumefaciens. Plant Physiology, v.91, p.1212-1218, 1989.

DAVIS, P.J. The plant hormones: their nature, occurences and functions. In: DAVIES, P.J. (Ed.). Plant hormones, physiology, biochemistry and molecular biology. Dordrecht: Kluer Academic Publishers, 1995. cap.1, p.1-13.

DE BLOCK, M.; BOTTERMAN, J.; VANDEWIELE, M.; DEKX, J.; THOEN, C.; GOSSElÉ, V.; MOVVA, N.R.; THOPSON, C.; VAN MONTAGU, M.; LEEMANS, J. Ingeneering herbicide in plants by expression of detoxifying enzyme. EMBO Journal, v.6, n.9, p.2513-2518, 1987.

DEKEYSER, R.; CLAES, B.; MARICHAL, M.; VAN MONTAGU, M.; CAPLAN, A. Evaluation of selectable markers for rice transformation. Plant Physiology, v.90, p.217-223, 1989. 
DE NEVE, M.; DE BUCK, S.; JACOBS, A.; VAN MONTAGU, M.; DEPICKER, A. TDNA integrations patterns in co-transformated plant cells suggest that T-DNA repeats originate from co-integration of separate T-DNAs. Plant Journal, v.11, p.15-29, 1997.

DIALO, N.; DUHOUX, E. Organogenese et multiplication in vitro chez l' Eucalyptus camaldulensis. Journal of Plant Physiology, v.115, p.177-182, 1984.

DURAND-CRESSWELL, R.; BOULAY, M.; FRACLET, A. Vegetative propagation of Eucalyptus. In: BOGA, J.M.; DURZAN, D.J. (Ed.). Tissue culture in forestry. Dordrecht: Martinus Nijhoff Publishers, 1985. cap.6, p.150-181.

ELDRIDGE, K.; DAVIDSON, J.; HARWOOD, C., VAN WYK, G. Eucalypt domestication and breeding. New York: Oxford University Press, 1994. p.288.

ESMERALDO, M.V.; CARVALHEIRA, S.A.; BARRUETO, C.P.; BRASILEIRO, A.C.M. Analysis of diferents parameter affecting Agrobaterium-mediated tyransformation of E.grandis $x$ E. urophylla. In: CONFERÊNCIA IUFRO SOB SILVICULTURA E MELHORAMENTO DE EUCALIPTOS, Salvador, 1997. Anais. Salvador: Editorial Colombo, 1997. v.1, p.24-29.

EVERETT, N.P.; ROBINSON, K.E.P.;MASCARENHAS, D. Genetic enginnnering of sunflower (Heliantus annus L.). Biotecnology, v.5, p.1201-1204, 1987.

FELDMANN, K.A.; MARKS, M.D. Agrobacterium transformation of germinating seeds of Arabidopsis thaliana: a non-tissue culture approach. Molecular General Genetics, v.208, p.1-9, 1987.

FERREIRA, M. Escolha de espécies de eucalipto. Piracicaba: ESALQ, Departamento de Ciências Florestais, 1979. 30p. (Circular Técnica IPEF, 47) 
GAMA, M.I.C. Identificação de plantas transgênicas por PCR. In: BRASILEIRO, A.C.M.; CARNEIRO, V.T.C. (Ed.). Manual de transformação genética de plantas. Brasília: EMBRAPA, SPI, 1998. cap.12, p.179-189.

GAMBORG, O.L.; SHYLUK, J.P. Nutrition media and characterístics of plant cell and tissue cultures. In: THORPE, R. (Ed.). Plant tissue culture, methods and applications in agriculture. New York: Academic Press, 1981. cap.2, p.21-44.

GARDNER, S. Plant viral vectors, CaMV as an experimental tool. In: KOSUGE, T.; MERDITH, C.P.; HOLLAE, A. (Ed.). Genetic engeneering of plants. New York: Plenum Press, 1983. cap.5, p.121-142.

GELVIN, B.S. Agrobacterium and plant genes involved in t-dna transfer and integration. Annual Review of Plant Physiology and Plant Molecular Biology, v.51, p.223256, 2000.

GONZALEZ, E. R.; ANDRADE, A.; BERTOLO, A. L.; LACERDA, G. C.; CARnEIRO, R. T.; DEFÁVARI, V. A. P.; LABATE, C. A. The efficiency of aminoglycoside antibiotics in the regeneration and selection of Eucalyptus spp. In: INTERNATIONAL CONFERENCE: EUCALYPTUS IN THE MEDITERRANEAN BASIN: PERSPECTIVES AND NEW UTILISATIONS, Taormina, 1999. Anais. Taormina: Centro Promozione Publicità Press, 2001. p.4548.

GRATTAPAGLIA, D.; BRADSHAW, H. D. Nuclear DNA content of commercially important Eucalyptus species and hybrids. Canadian Journal of Forest Research, v.24, n.5, p.1074-1078, 1994.

HAMILL, J.; ROUNSLEY, S.; SPENCER, A.; TODD, G.; RHODES, M. The use of the polymerase chain rection in plant transformation studies. Plant Cell Reports, v.10, p.221-224, 1991. 
HANDRO, W.; FLOH, E.I.S. Aspectos básicos do controle da morfogênese in vitro. In: TORRES, A.C.; CALDAS, L.S. (Ed.). Técnicas e aplicações da cultura de tecidos de plantas. Brasília: EMBRAPA, CNPH, 1990. p.203-212.

HARE, P.D.; VAN STADEN, J. Inhibitory effect thidiazuron on the activity of cytokinin oxidase isolated from soybean callus. Plant Cell Physiology, v.35, p.1121-1125, 1994.

HO, C.K.; CHANG, S.H.; TSAY, J.Y.; TSAI, C.J.; CHIANG, V.L.; CHEN, Z.Z. Agrobacterium tumefaciens mediated transformation of Eucalyptus camaldulensis and production of transgenic plants. Plant Cell Reports, v.17, n.9, p.675-680, 1998.

HODAL, L.; BOCHARDT, A.; NIELSEN, J. E.; MATTSSON, O.; OKKELS, F. T. Detection expression and specific elimination of endogenous $\beta$-glucuronidase in transgenic and non-transgenic plants. Plant Science, v.87, p.115-121, 1992.

HORGAN, K. Pinus radiata. In: BOGA, J.M.; DURZAN, D.J. (Ed.). Tissue culture in foresty. Dordrecht: Martinus Nijhoff Publishers, 1987. cap.3, p 128-145.

HU, C. Y.; CHEE, P.P.; CHESNEY, R.H.;ZHOU, J.H.; MILLER, P.D. Intrinsic GUSlike activities in seed plants. Plant Cell Reports, v.9, p.1-5, 1990.

HUETTEMAN, C.A.; PREECE, J.E. Thidiazuron: a potent cytokinin for woody plant tissue culture. Plant Cell Tissue and Organ Culture, v.33, p.105-119, 1993.

ISHIDA, Y.; SAITO, H.; OHTA, S.; HIEI, Y.; KOMARI, T.; KUMASHIRO, T. High efficiency transformation of maize (Zea mays L.) mediated by Agrobacterium tumefaciens. Nature Biotechnology, v.14, p.745-750, 1996.

JACQ, B.; LESOBRE, O.; SANGWAN, R.S.; NORRELL, S.S. Factors influencing TDNA transfer in Agrobacterium mediated transformation of sugarbeet. Plant Cell Reports, v.12, p.621-624, 1993. 
JANSSEN, B.J.; GARDNER, R.C. The use of transient GUS expression to develop an Agrobacterium mediated gene transfer system for kiwifruit. Plant Cell Reports, v.13, p.28-31, 1993.

JEFFERSON, R.A.; KAVANAGH, T.A.; BEVAN, M.W. Gus fusions betaglucuronidase as a sensitive and versatile gene fusion marker in higher plants. EMBO Journal, v.6, n.13, p.3901-3907, 1987.

JEFFERSON, R.A.; BURGESS, S.M.; HIRSH, D. $\beta$-glucuronidase from Escherichia coli as a gene fusion marker. Proceedings of the National Academy Science of USA, v.83, p.8447-8451, 1986.

JIA, R. S.; YANG, M.Z.; OTT, R.; CHUA, N.H.. High frequency transformation of Kalanchoe laciniata. Plant Cell Reports, v.8, p.336-340, 1989.

JOERSBO, M.; BRUNSTEDT, J. Sonication: a new method for gene-transfer to plants. Physiologia Plantarum, v.85, n.2, p.230-234, 1992.

KANG, H.; CHUN, Y.W. Plant regeneration through organogenesis in poplar. In: KLOPFENSTEIN, N.B.; CHUN, Y.W.; KIM, M.S.; AHUJA, R.M. (Ed.). Micropropagation, genetic engeneering and molecular biology of Populus. Colorado: Fort Collins, 1997. cap.3, p.13-23.

KIELLY, G.; BROWLEY, S. Genetic control of somatic embryogenesis in alfalfa. Genome, v.35, p.474-477, 1992.

KLEE, H.; YANOFSKY, M.F.; NESTER, E.W. Vectors for transformation of higher plants. Biotechnology, v.3, p.637-642, 1985.

KLEIN, T.M.; WOLF, E.D.; WU, R.; SANFORD, J.C. High velocity microprojectiles for delivering nucleic acids into living cells. Nature, v.327, p.70-73, 1987. 
KONCZ, C.; NEMETH, N.; REDEI, G.P.; SCHELL, J. T-DNA insertional mutagenesis in Arabidopsis. Plant Molecular Biology, v.20, p.963-976, 1992.

LACORTE, C. $\beta$-Glucuronidase. In: BRASILEIRO, A.C.M.; CARNEIRO, V.T.C. (Ed.). Manual de transformação genética de plantas. Brasília: EMBRAPA, SPI, 1998. cap.8, p.127-141.

LAINE, E.; DAVID, A. Regeneration of plants from leaf explants of micropropagated clonal Eucalyptus grandis. Plant Cell Reports, v.13, n.8, p.473-476, 1994.

LEROUX, J.J.; VANSTADEN, J. Micropropagation and tissue culture of Eucalyptus a review. Tree Physiology, v.9, n.4, p.435-477, 1991.

LI, X.B.; BAI, Y.Y.; XU, Z.H. WEI, Z.M. Study on the conditions of cell transformation in Astragalus sinicus. Acta Botanica Sinica, v.36, p.437-443, 1994.

LINDSEY, K. Genetic transformation of crop plants. Journal of Biotechnology, v.26, p.1-28, 1992.

LU, C.Y. The use of thidiazuron in tissue culture. In Vitro Cellular and Developmental Biology, v.29, p.92-96, 1993.

LUTOVA, L.A.; PAVlOVA, B.Z.; IVANOVA, M.M. Agrobacterium mediated transformation as a way to change hormonal metabolism in high plants. Russian Journal of Genetic, v.34, n.2, p.109-123.

MACHADO, L.D.R.; ANDRADE， G.M.; CID， L.P.B.; PENCHEL， R.M.; BRASILEIRO, A.C.M. Agrobacterium strain specificity and shooty tumour formation in eucalypt (Eucalyptus grandis X Eucalyptus urophylla). Plant Cell Reports, v.16, n.5, p.299-303, 1997. 
MAURO, A.O.; PFEIFFER, T.W.; COLLINS, G.B. Inheritance of soybean susceptibility to Agrobacterium-tumefaciens and its relationship to transformation. Crop Science, v.35, n.4, p.1152-1156, 1995.

MAYER, A.M. Polyphenol oxidases in plants recent progress. Phytochemistry, v.26, p.787-791, 1987.

MCCOWN, D.D.; SELLMER, J.C. General media and vessels suitable for woody plant microculture. In: BONGA, J.M.; DURZAN, D.J. (Ed.). Cell and tissue culture in forestry. Dordrecht: Martinus Nijhoff Publishers, 1987. cap.1, p.4-14.

MORALEJO, M.; ROCHANGE, F.; BOUDET, A.M.; TEULIERES, C. Generation of transgenic Eucalyptus globulus plantlets through Agrobacterium tumefaciens mediated transformation. Australian Journal of Plant Physiology, v.25, n.2, p.207-212, 1998.

MORAN, GF; BELL, JC. Eucalyptus. In: TANSLEY, D.S.; ORTON, T.J. (Ed.). Isoenzimes in plant genetics and breeding. Amsterdam: Elsevier, 1983. Part B, p.423-441.

MULLINS, K.V.; LLEWELLYN, D.J.; HARTNEY, V.J.; STRAUSS, S.; DENNIS, E.S. Regeneration and transformation of Eucalyptus camaldulensis. Plant Cell Reports, v.16, n.11, p.787-791, 1997.

MULLINS, K.B.; FALOONA, F. Specific synthesis od DNA in vitro via a polimerase catalized chain reaction. Methods of Enzymology, v.155, p.335-348, 1987.

MURALIDHARAN, E.M.; MASCARENHAS, A.F. In vitro plantlet formation by organogeneses in Eucalyptus camaldulensis and by somatic embryogenesis in Eucalyptus citriodora. Plant Cell Reports, v.6, p.256-259, 1987. 
MURALIDHARAN, E.M.; GUPTA, P.K.; MASCARENHAS, A.F. Plantlet production through high frequency somatic embryogenesis in long term cultures of Eucalyptus citriodora. Plant Cell Repprts, v.8, p.41-43, 1989.

MURASHIGE, T.; SKOOG, F. A revised medium for rapid growth and bio assays with tabacco tissue cultures. Physiologia Plantarum, v.15, n.3, p.473-497, 1962.

NAM, J.; MATTHYSSE, A.G.; GELVIN, S.B. Differences in susceptibility of Arabidopsis ecotypes to crown gall disease may result from a deficiency in T-DNA integration. Plant Cell, v.9, n.3, p.317-333, 1997.

NEUHAUS, G.; SPANGENBERG, G. Plant transformation by microinjection techniques. Physiologia Plantarum, v.79, p.213-217, 1990.

NORELLI, J. L.; ALDWINCKLE, S. H. The role of aminoglycosides antibiotics in the regeneration and selection of neomicin phosphotransferase transgenic apple tissue. Journal American Society Horticultural Science, v.118, p.311-316, 1993.

NOVOA, C.O.; COLES, G. Computer image analysis to quantify and análise stable transformation identified using the histochemical GUS assay. Plant Molecular Biology Reports, v.12, p.146-151, 1994.

OHBA, T.; YOSHIOKA, Y.; MACHIDA, C.; MACHIDA, Y. DNA rearrangement associated with the integration of T-DNA in tobacco: an example for multiple duplications of DNA around the integration target. Plant Journal, v.7, p.157-164, 1995.

OUYANG, Q.; PENG, H.; LI, Q. Studies on the development of embryoids from Eucalyptus callus. Science Silvae Sinica, v.17, p.1-7, 1981. 
PARK, Y.G.; SON, S.H. Somatic embryogenesis from poplar leaf tissue. In: KLOPFENSTEIN, N.B.; CHUN, Y.W.; KIM, M.S.; AHUJA, R.M. (Ed.). Micropropagation, genetic engeneering and molecular biology of Populus. Colorado: Fort Collins, 1997. cap.2, p.13-23.

PLEGT, L.; BINO, R.J. $\beta$-glucuronidase activity during development of the male gametophyte from transgenic and non-transgenic plants. Molecular and General Genetics, v.216, p.321-327, 1989.

POTRYKUS, I.; SHILLITO, R.; AS, M.; PASZKOWSKI, J. Direct gene transfer state of the art and future potencial. Plant Molecular Biology Reports, v.3, p.117-128, 1985.

POTRYKUS I. Gene transfer to plants: assessment of published approaches and results. Annual Review of Plant Physiology, v.42, p.205-225, 1991.

POTRYCUS, I.; SPANGENBER, G.G. Gene tranfer to plant. Springer: Laboratory Manual, 1995. 328p.

PRYOR, L. D. Selecting and breeding for cold resistance in Eucalyptus. Silvae Genetica, v.6, p.98-109, 1957.

PRYOR, L. D. The biology of eucalypts. London: Edward Arnold, 1976. 82p.

REAM, W. Agrobacterium tumefaciens and interkingdom genetic exchange. Annual Review of Phytopathology, v.27, p.583-586, 1989.

ROBBS, S.L.; HAWES, M.C.; LIN, H.J.; PUEPPKE, S.G.; SMITH, L.Y. Inheritance of resistance to crown gall in Pisum sativum. Plant Physiology, v.95, n.1, p.52-57, 1991. 
ROMANO, E. Análise da integração do DNA pela técnica de Southern Blot. In: BRASILEIRO, A.C.M.; CARNEIRO, V.T.C. (Ed.). Manual de transformação genética de plantas. Brasília: EMBRAPA, SPI, 1998. cap.14, p.205-222.

RUSSELL, J.A.; ROY, M.K.; SANFORD, J.C. Physical trauma and tungsten toxicity reduce the efficiency of biolistic transformation. Plant Physiology, v.98, n.3, p.1050-1056, 1992.

RUGGERI, M. Contributo alla cariologia del genere Eucalyptus (Myrtaceae). Caryologia, v.14, p.111-120, 1961.

SAMBROOK, J.; FRITSCH, E.F.; MANIATIS, T. Molecular cloning: a laboratory manual. 2.ed. New York: Cold Spring Harbor, 1989. 213p.

SANGWAN, R.S.; BOURGEOS, G.; NORRELL, S.W. Genetic transformation of Arabidopsis thaliana zygotic embryos and identification of critical parameters influencing transformation efficiency. Molecular General Genetics, v.230, p.475$485,1991$.

SANTAREM, E.R.; TRICK, H.N.; ESSIG, J.S.; FINER, J.J. Sonication assisted Agrobacterium-mediated transformation of soybean immature cotyledons: optimization of transient expression. Plant Cell Reports, v.17, n.10, p.752-759, 1998.

SAS INSTITUTE. SAS/STAT user's guide. Release 6.11 edition. Cary, 1996. p.587.

SERRANO, L.; ROCHANGE, F.; SEMBLAT, J.P.; MARQUE, C.; TEULIERES, C.; BOUDET, A.M. Genetic transformation of Eucalyptus globulus through biolistics: complementary development of procedures for organogenesis from zygotic embryos and stable transformation of corresponding proliferating tissue. Journal of Experimental Botany, v.47, n.295, p.285-290, 1996. 
SKOOG, F; MILLER, C.O. Chemical regulation of growth and organ formation in plant tissue culture in vitro. Symposium of Society for Experimental Biology, v.11, p.118-131, 1957.

SOCIEDADE BRASILEIRA DE SILVICULTURA. Eucalipto no Brasil e no mundo. http://www.floresta.ipef.br. (Agosto, 2000)

SONGSTAD, D.D.; SOMERS, D.A.; GRIESSBACH, R.J. Advances in alternative DNA delivery techniques. Plant Cell Tissue Organ Culture, v.40, p.1-15, 1995.

SOURTHERN, E. M. Detection of specific sequencies among DNA fragment separated by gel electrophoresis. Journal of Molecular Biology, v.98, p.503-517, 1975.

STACHEL, S.E.; MESSENS, E.; VANMONTAGU, M.; ZAMBRYSKI, P. Identification of the signal molecules produced by wounded plant cells that activate T-DNA transfer in Agrobacterium tumefaciens. Nature, v.318, n.6047, p.624-629, 1985.

SUBBAIAH, M.M.; MINOCHA, S.C. Shoot regeneration from stem and leaf callus of Eucalyptus tereticornis. Plant Cell Reports, v.9, n.7, p.370-373, 1990.

SULLIVAN, J.; LAGRIMINI, L. M. Transformation of Liquidambar styraciflua using Agrobacterium tumefaciens. Plant Cell Reports, v.12, p.303-306, 1993.

TAKAHASHI, S.; SHUDO, K.; OKAMOTO, T. YAMADA, K.; ISOGAI, Y.O. Cytokinin activity of N-Phenyl-N'-(4-PYRIDYL) urea derivatives. Phytochemistry, v.17, p.1201-1207, 1978.

TERMIGNONI, R.R.; WANG, P.J.; HU, C.Y. Somatic embryo induction in Eucalyptus dunnii. Plant Cell Tissue and Organ Culture, v.45, p.129-132, 1996. 
TIBOK, A.; BLACKHALL, N.W.; POWER, J.B.; DAVEY, M.R. Optimized plant regeneration from callus derived from seedling hypocotyls of Eucalyptus urophylla. Plant Science, v.110, n.1, p.139-145, 1995.

TÖR, M.; MANTELL, S.H.; AINSWORTH, C. Endophytic bacteria expressing $\beta$ glucuronidase cause false positive in Discorea species. Plant Cell Reports, v.11, p.452-456, 1992.

TREXLER, M. C.; FAETH, P. E.; KRAMER, J. M. Forestry as a response to a global warming: an analysis of the Guatemala agroforestry and carbon sequestrion project. Washington: World Resources Institute, 1989. 66p.

TRICK, H.N.; FINER, J.J. SAAT: sonication-assisted Agrobacterium mediated transformation. Transgenic Research, v.6, n.5, p.329-336, 1997.

TRICK, H.N.; FINER, J.J. Sonication assisted Agrobacterium mediated transformation of soybean [Glycine max (L.) Merrill] embryogenic suspension culture tissue. Plant Cell Reports, v.17, n.6-7, p.482-488, 1998.

TSAI, C.J.; PODILA, G. K.; CHIANG, V. L. Agrobacterium-mediated transformation of quaking aspen (Populus tremuloides) and regeneration of transgenic plants. Plant Cell Reports, v.14, p.94-97, 1994.

TSURO, M.; KODA, M.; INOUE, M. Comparative effect of different types of cytokinin for shoot formation and plant regeneration in leaf derived callus of lavender (Lavandula vera DC). Scientia Horticulture, v.81, p.331-336, 1999.

VASIL, V.; BROWN, S.; RE, D.; FROMM, M. E.; VASIL, I. Stable transformed callus line from microprojectile bombardement of the cells suspension cultures of wheat. Biotechnology, v.9, p.743-747, 1991. 
VENKATESH, C. S.; ARYA, R. S.; SHARMA, V. K. Natural selfing in planted Eucalyptus and its estimation. Journal of Plantion Crops, v.1, p.23-25, 1973.

VERGUNST, A.C.; HOOYKAAS, J.P. Recombination in the plant genome and its application in biotechnology. Critical Review in Plant Science, v.18, n.1, p.1-31, 1999.

VILLEMONT, E.; DUBOIS, F.; SANGWAN, R.S.; VASSEUR, G.; BOURGEOIS, Y.; SANGWAN-NORREEL, B.S. Role of the host cell cycle in the Agrobacterium mediated genetic transformation of Petunia: evidence of an S-phase control mechanism for T-DNA transfer. Planta, v.201, p.160-172, 1997.

WATT, M.P.; BLAKEWAY, F.; CRESSWELL, C.F.; HERMAN, B. Somatic embryogenesis in Eucalyptus grandis. South African Forestry Journal, v.157, p.59-65, 1991.

WILMINK, A.; VEM, B.C.E.; CUSTERS, J.B.M.; NOLLEN, Y.; DONS, J.J.M. Adventitious shoot formation in tulip: histological analysis and response to selective agents. Plant Science, v.110, p.155-164, 1995.

WILMINK, A.; DONS, J.J.M. Selective agents and marker genes for use in transformation in monocotyledonous plants. Plant Molecular Biology Reports, v.11, p.165-185, 1993.

WORDRAGEN, M.F.; DONS, H.J.M. Agrobacterium tumefaciens mediated recalcitrant crops. Plant Molecular Biology Reports, v.10, p.12-36, 1992.

YANG, J.C.; CHUNG, J.D.; CHEN, Z.Z. Vegetative propagation of adult Eucalyptus grandis $X$ urophylla and comparison of growth between micropropagated plantlets and rooted cuttings. Plant Cell Reports, v.15, n.3-4, p.170-173, 1995. 
ZHANG, Z.; COYNE, D.P.; MITRA, A. Factors affecting Agrobacterium-mediated transformation of common bean. Journal of American Society Horticultural Science, v.122, p.300-305, 1997. 